\title{
NEUTRONIC EVALUATION OF A NON-FERTILE FUEL FOR THE DISPOSITION OF WEAPONS-GRADE PLUTONIUM IN A BOILING WATER REACTOR
}

\section{J. W. STERBENTZ}

\author{
Idaho National Engineering Laboratory \\ P.O. Box 1625 \\ Idaho Falls, Idaho 83415-3885
}

September 1994

Prepared for the U.S. Department of Energy through the INEL LDRD Program Under DOE Idaho Operations Office Contract DE-AC07-94ID13223 


\begin{abstract}
A new non-fertile, weapons-grade plutonium oxide fuel concept is developed and evaluated for "deep burn" applications in a boiling water reactor environment using the General Electric 8x8 Advanced Boiling Water Reactor (ABWR) fuel assembly dimensions and pitch. Detailed infinite lattice fuel burnup results and neutronic performance characteristics are given and although preliminary in nature, clearly demonstrate the fuel's potential as an effective means to expedite the disposition of plutonium in existing light water reactors.
\end{abstract}

The new non-fertile fuel concept is an all oxide composition containing plutonia, zirconia, calcia, and erbia $\left(\mathrm{PuO}_{2}-\mathrm{ZrO}_{2}-\mathrm{CaO}-\mathrm{Er}_{2} \mathrm{O}_{3}\right)$ having the following design weight percentages:

\begin{tabular}{lc} 
Constituent & wt\% \\
\hline Plutonia $\left(\mathrm{PuO}_{2}\right)$ & 8.3 \\
Zirconia $\left(\mathrm{ZrO}_{2}\right)$ & 80.4 \\
Calcia $(\mathrm{CaO})$ & 9.7 \\
Erbia $\left(\mathrm{Er}_{2} \mathrm{O}_{3}\right)$ & 1.6
\end{tabular}

This $\mathrm{PuO}_{2}-\mathrm{ZrO}_{2}-\mathrm{CaO}-\mathrm{Er}_{2} \mathrm{O}_{3}$ fuel composition in an infinite fuel lattice operating at linear heat generation rates of 6.0 or $12.0 \mathrm{~kW} / \mathrm{ft}$ per rod can remain critical for up to 1200 and 600 Effective Full Power Days (EFPD), respectively, and achieve a burnup of $7.45 * 10^{20} \mathrm{f} / \mathrm{cc}$. These burnups correspond to a 71-73\% total plutonium isotope destruction and a 91-94\% destruction of the ${ }^{239} \mathrm{Pu}$ isotope for the $0-40 \%$ moderator steam void condition. Total plutonium destruction greater than $73 \%$ is possible with a fuel management scheme that allows subcritical fuel assemblies to be driven by adjacent high reactivity assemblies.

The $\mathrm{PuO}_{2}-\mathrm{ZrO}_{2}-\mathrm{CaO}-\mathrm{Er}_{2} \mathrm{O}_{3}$ fuel exhibits very favorable neutron characteristics from beginningof-life (BOL) to end-of-life (EOL). Prompt fuel Doppler coefficients of reactivity are negative, with values ranging between -0.4 to $-2.0 \mathrm{pcm} / \mathrm{K}$ over the temperature range of 900 to $2200 \mathrm{~K}$. Steam void coefficients of reactivity are also negative, ranging between -0.1 to -0.5 over the 10 to $90 \%$ moderator steam void range. Isothermal temperature coefficients are strongly negative at BOL and tend to become less negative with burnup, until near EOL when the coefficients become positive. In addition, despite the relatively low BOL plutonium rod mass concentrations (approximately 132 $\mathrm{g} /$ rod Pu metal), the ABWR fuel lattice remains in an undermoderated condition for both hot operational and cold startup conditions over the entire fuel burnup lifetime. 


\section{DISCLAIMER}

This report was prepared as an account of work sponsored by an agency of the United States Government. Neither the United States Government nor any agency thereof, nor any of their employees, make any warranty, express or implied, or assumes any legal liability or responsibility for the accuracy, completeness, or usefulness of any information, apparatus, product, or process disclosed, or represents that its use would not infringe privately owned rights. Reference herein to any specific commercial product, process, or service by trade name, trademark, manufacturer, or otherwise does not necessarily constitute or imply its endorsement, recommendation, or favoring by the United States Government or any agency thereof. The views and opinions of authors expressed herein do not necessarily state or reflect those of the United States Government or any agency thereof. 


\section{DISCLAIMER}

Portions of this document may be illegible in electronic image products. Images are produced from the best available original document. 


\section{CONTENTS}

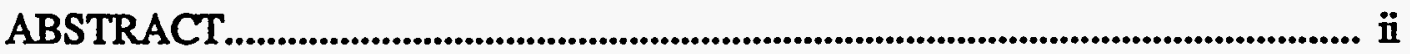

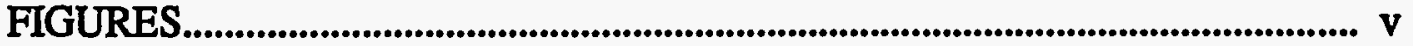

TABLES............................................................................................................................ vii

ACRONYMS.............................................................................................................. viii

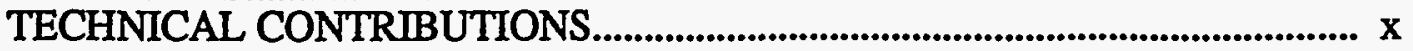

1.0 INTRODUCTION................................................................................. 1

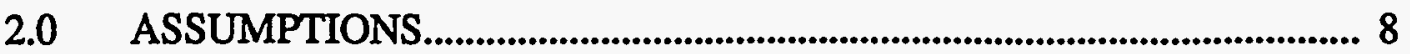

3.0 COMPUTER CODES.............................................................................. 9

4.0 NEUTRON CROSS SECTION DEVELOPMENT...................................... 10

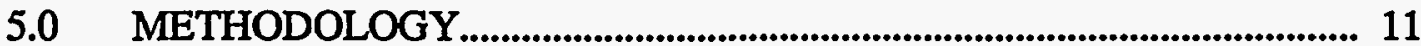

5.1 MCNP Unit Cell Model Description.......................................... 11

5.2 COMBINE Pin Cell Model Description........................................... 12

5.3 Burnup Calculations......................................................................... 12

6.0 NEUTRONIC EVALUATION - $\mathrm{PuO}_{2}-\mathrm{ZrO}_{2}$-CaO FUEL.......................... 16

6.1 Undermoderated or Overmoderated Lattice................................... 16

6.2 Moderator Steam Void Coefficient.............................................. 18

6.3 Cross Section Variation with Steam Void........................................ 18

6.4 Doppler Coefficient.................................................................... 23

6.5 Isothermal Temperature Coefficient........................................... 23

6.6 Burnable Poison Additives.......................................................... 23

7.0 NEUTRONIC EVALUATION -- $\mathrm{PuO}_{2}-\mathrm{ZrO}_{2}-\mathrm{CaO}-\mathrm{Er}_{2} \mathrm{O}_{3}$ FUEL............... 27

7.1 Lattice k-infinity versus Erbia Concentration................................. 27

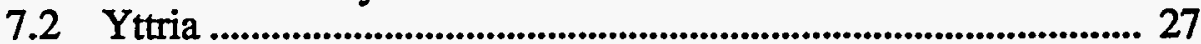

7.3 Criticality of a Single Fuel Assembly in Air................................. 29

7.4 ABWR Pitch........................................................................... 29

7.5 Burnup Calculations............................................................... 29

7.6 Plutonium Destruction................................................................ 33

7.7 Higher-Order Actinides............................................................ 33

7.8 Moderator Steam Void Coefficient.............................................. 33

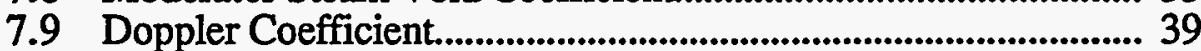

7.10 Isothermal Temperature Coefficient............................................. 39

7.11 Pellet Radial Power Distribution Comparison................................ 45

7.12 Cross Section Variation with Burnup.............................................. 45

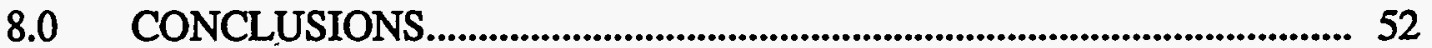

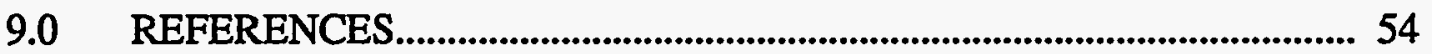

APPENDIX A--FUEL ATOMIC NUMBER DENSITIES........................................ A-1 


\section{CONTENTS}

APPENDIX B-NEUTRON CROSS SECTION DEVELOPMENT....................... B-1

APPENDIX C--MODERATOR/COOLANT ATOMIC NUMBER DENSITIES AT SATURATION CONDITIONS.............................................. C-1

APPENDIX D--CLAD ATOMIC NUMBER DENSITIES..................................... D-1 


\section{FIGURES}

1. Non-fertile fuel concept for a Boiling Water Reactor.......................................... 2

2. ABWR lattice geometry and dimensions........................................................... 3

3. K-infinity versus pitch and different $\mathrm{BOL}$ plutonium fuel rod mass loadings at hot operational conditions with a $40 \%$ moderator steam void ....... 17

4. K-infinity versus pitch for variable moderator steam void at hot and cold conditions with a constant $5.69 \mathrm{wt} \% \mathrm{PuO}_{2}$ rod mass loading.......................... 19

5. K-infinity as a function of moderator steam void percentage for the ABWR lattice, hot operational conditions, and a $5.69 \mathrm{wt} \% \mathrm{PuO}_{2}$ fuel rod mass loading.

6. Steam void coefficient of reactivity as a function of moderator steam void percentage for the ABWR lattice, hot operational conditions, and a $5.69 \mathrm{wt} \% \mathrm{PuO}_{2}$ fuel rod mass loading

7. Plutonium isotope cross sections as a function of moderator steam void percentage for the $A B W R$ lattice and a $5.69 \mathrm{wt} \% \mathrm{PuO}_{2}$ fuel rod mass loading.

8. Fuel Doppler coefficients as a function of fuel temperature and moderator steam void for the ABWR lattice pitch, hot operational conditions, and a $5.69 \mathrm{wt} \% \mathrm{PuO}_{2}$ fuel rod mass loading.

9. K-infinity as a function of burnup for a constant fuel rod LHGR of $6.0 \mathrm{~kW} / \mathrm{ft}$ in an infinite $\mathrm{ABWR}$ lattice for $8.4 \mathrm{wt} \% \mathrm{PuO}_{2}$ fuel rods containing various rare-earth burnable poisons.

10. K-infinity as a function of erbia volume fraction in the fuel for three different $\mathrm{PuO}_{2}$ fuel rod mass loadings

11. K-infinity comparison between $\mathrm{PuO}_{2}-\mathrm{ZrO}_{2}-\mathrm{CaO}-\mathrm{Er}_{2} \mathrm{O}_{3}$ and a $\mathrm{PuO}_{2}-\mathrm{ZrO}_{2}-\mathrm{Y}_{2} \mathrm{O}_{3}-\mathrm{Er}_{2} \mathrm{O}_{3}$ fuel as a function of erbia volume fraction.

12. K-infinity as a function of lattice pitch and BOL hot-operating and cold-startup reactor conditions

13. K-infinity as a function of burnup, linear heat generation rate, and moderator steam void for steady-state hot operating conditions using the ABWR lattice pitch

14. Fuel rod plutonium isotopic mass concentrations as a function of burnup for the $40 \%$ moderator steam void and $6.0 \mathrm{~kW} / \mathrm{ft}$ LHGR case.

15. Fuel rod erbium isotopic mass concentrations as a function for the $40 \%$ moderator steam void and $6.0 \mathrm{~kW} / \mathrm{ft}$ LHGR case. 


\section{FIGURES}

16. K-infinity as a function of moderator steam void and burnup for steady-state hot operating conditions and a $6.0 \mathrm{~kW} / \mathrm{ft}$ fuel rod LHGR

17. Steam void coefficient of reactivity as a function of moderator steam void and burnup for for steady-state hot operating conditions.and a $6.0 \mathrm{~kW} / \mathrm{ft}$ fuel rod LHGR

18. K-infinity as a function of moderator void and burnup for cold start-up conditions (room temperature).

19. Void coefficient of reactivity as a function of moderator void and burnup for cold start-up conditions (room temperature)

20. Doppler temperature coefficients of reactivity as a function of moderator steam void and fuel burnup at hot operating conditions

21. Isothermal temperature coefficients of reactivity as a function of burnup at hot operating conditions

22. Isothermal temperature coefficients of reactivity at BOL showing the increase in negative magnitude with the addition of erbia to the $\mathrm{PuO}_{2}-\mathrm{ZrO}_{2}-\mathrm{CaO}$ fuel composition

23. Comparison of fuel pellet radial power distributions for two $L W R$ fuels, $\mathrm{UO}_{2}$ and $\mathrm{UO}_{2}-\mathrm{Gd}_{2} \mathrm{O}_{3}$, and the non-fertile $\mathrm{PuO}_{2}-\mathrm{ZrO}_{2}-\mathrm{CaO}-\mathrm{Er}_{2} \mathrm{O}_{3}$ fuel....... 46

24. Plutonium fission and capture cross sections as a function of burnup

25. Erbium isotopic capture cross sections as a function of burnup ...................... 48

26. Fission product capture cross sections as a function of burnup ...................... 49

27. Fission product mass as a function of burnup ............................................... 51 


\section{TABLES}

1. List of the fuel nuclides/isotopes whose neutron cross sections are updated with each burnup time step...................................................................................... 13

2. Time points over the burnup period in which neutron cross sections are calculated by MCNP and updated for the next ORIGEN2 burnup calculation

3. Plutonia weight percent mass loading and corresponding weapons-grade plutonium metal per fuel rod for the $\mathrm{PuO}_{2}-\mathrm{ZrO}_{2}-\mathrm{CaO}$ fuel composition.

4. Volume, atom, and weight percentages of the constituent materials in the $\mathrm{PuO}_{2}-\mathrm{ZrO}_{2}-\mathrm{CaO}-\mathrm{Er}_{2} \mathrm{O}_{3}$ fuel composition.

5. Isotopic and total plutonium rod masses at BOL and EOL along with the maximum percent plutonium destruction and destruction rate for the given EFPD after which the fuel lattice goes subcritical 


\section{ACRONYMS}

$\mathrm{ABH}$

ABWR

$\mathrm{Al}_{2} \mathrm{O}_{3}$

at\%

ATR

B

$\mathrm{BeO}$

BOL

BWR

C

$\mathrm{cm}$

CF

$\mathrm{CaO}$

CISAC

COMBINE

EFPD

EOL

Er

$\mathrm{Er}_{2} \mathrm{O}_{3}$

$\mathrm{Eu}$

$\mathrm{Eu}_{2} \mathrm{O}_{3}$

$\mathrm{F}$

f/cc

$\mathrm{g}$

$\mathrm{g} / \mathrm{cm}$

g/rod

Gd

$\mathrm{Gd}_{2} \mathrm{O}_{3}$

GE

GWD/MT

in

INEL

IR

ITC

$\mathrm{K}$

$k_{\text {inf }}$

kW

$\mathrm{kW} / \mathrm{ft}$

LDRD

LHGR

LWBR

LWR

MCNP

MOX

MT

MTR

MW
Amouyal, Benoist, and Horowitz thermal disadvantage factor method

Advanced Boiling Water Reactor

aluminum oxide or alumina

atom percent

Advanced Test Reactor

boron

beryllium oxide or beryllia

Beginning-of-Life

Boiling Water Reactor

calcia volume fraction in the fuel composition

centimeters

Capacity Factor

calcium oxide or calcia

Committee on International Security and Arms Control

Neutron spectrum and cross section generation computer code

Effective Full Power Days

End-of-Life

erbium

erbium oxide or erbia

europium

europium oxide or europia

degrees Fahrenheit

fissions per cubic centimeter

gram

grams per centimeter

grams per fuel rod

gadolinium

gadolinium oxide or gadolinia

General Electric

Gigawatt-days per metric ton

inch

Idaho National Engineering Laboratory

inner radius

Isothermal temperature coefficient of reactivity

degrees Kelvin

infinite multiplication constant

kilowatts

kilowatts per linear foot

Laboratory Directed Research and Development

Linear Heat Generation Rate

Light Water Breeder Reactor

Light Water Reactor

Monte Carlo N-Particle computer code

uranium-plutonium mixed oxide fuel

Metric Ton

Materials Test Reactor

Megawatts 


\section{ACRONYMS}

$\begin{array}{ll}\text { NAS } & \text { National Academy of Sciences } \\ \text { OD } & \text { outer diameter } \\ \mathrm{PBF} & \text { Power Burst Facility } \\ \text { pcm } & \text { percent milli }\left(10^{-5}\right) \\ \mathrm{PNL} & \text { Pacific Northwest Laboratory } \\ \text { psig } & \text { pound per square inch gauge pressure } \\ \mathrm{Pu} & \text { plutonium } \\ \mathrm{PuO}_{2} & \text { plutonium oxide or plutonia } \\ \mathrm{PWR} & \text { Pressurized Water Reactor } \\ \mathrm{SRL} & \text { Savannah River Laboratory } \\ \mathrm{TD} & \text { theoretical density } \\ \mathrm{Th} & \text { thorium } \\ \mathrm{ThO} & \text { thorium oxide or thoria } \\ \mathrm{U} & \text { uranium } \\ \mathrm{UO} & \text { uranium oxide or urania } \\ \mathrm{VF} & \text { volume fraction } \\ \mathrm{w} & \text { burnable poison volume fraction in the fuel composition } \\ \mathrm{wt} \% & \text { weight percent } \\ \mathrm{X} & \text { plutonia volume fraction in the fuel composition } \\ \mathrm{Y} & \text { yttrium } \\ \mathrm{Y}_{2} \mathrm{O}_{3} & \text { yttrium oxide or yttria } \\ \mathrm{Z} & \text { zirconia volume fraction in the fuel composition } \\ \mathrm{Zr} & \text { zirconium } \\ \mathrm{ZrO} & \text { zirconium oxide or zirconia }\end{array}$




\section{TECHNICAL CONTRIBUTIONS}

C.A. Wemple and S. Mason provided numerous MCNP neutron cross section libraries that were vital for this LDRD neutronic analysis study. Cross sections were developed for all the plutonium, zirconium, erbium, hafnium, samarium, europium, and gadolinium isotopes, and each isotope was evaluated at six different temperatures. Recognition is given to them for their diligence and timeconsuming efforts in generating these cross section sets and delivering them in a very timely manner.

C.S. Olsen added valuable technical input in the selection and design of our non-fertile fuel constituents and concentrations. Olsen is also the author of the companion LDRD study, entitled "Material Properties of a Non-fertile Fuel for the Disposition of Weapons-grade Plutonium in Light Water Reactors". 


\title{
1.0 INTRODUCTION
}

The primary objective of this Laboratory Directed Research and Development (LDRD) study is to neutronically evaluate and design a non-fertile, weapons-grade plutonium oxide fuel form suitable for use in a commercial boiling water reactor using the General Electric 8x8 Advanced Boiling Water Reactor (ABWR) lattice dimensions. The neutronic analyses are preliminary investigations and cursory in nature with the intention of providing general insights into important reactor physics parameters and trends. In addition, this study provides fuel constituent concentrations for use in a companion LDRD study that will analytically evaluate the non-fertile fuel composition material properties (e.g. density, thermal conductivity, phase equilibria) and irradiation performance behavior (e.g. fission gas release).

The fuel form adopted in this study, namely, the all oxide plutonia-zirconia-calcia-erbia (PuO2$\mathrm{ZrO}_{2}-\mathrm{CaO}_{-} \mathrm{Er}_{2} \mathrm{O}_{3}$ ) fuel form, has been selected based on results from a previous non-fertile fuel study $^{2}$ using a Pressurized Water Reactor (PWR) lattice and operating environment. The nonfertile PWR study neutronically evaluated the following seven all oxide fuel compositions at beginning-of-life (BOL) concentrations based on an assumed BOL excess reactivity level (infinite lattice $\left.\mathrm{k}_{\mathrm{inf}}=1.4\right)$ :

$$
\begin{aligned}
& \mathrm{PuO}_{2}-\mathrm{ZrO}_{2} \\
& \mathrm{PuO}_{2}-\mathrm{ZrO}_{2}-\mathrm{ThO}_{2} \\
& \mathrm{PuO}_{2}-\mathrm{ThO}_{2} \\
& \mathrm{PuO}_{2}-\mathrm{ThO}_{2}-\mathrm{Gd}_{2} \mathrm{O}_{3} \\
& \mathrm{PuO}_{2}-\mathrm{ZrO}_{2}-\mathrm{Gd}_{2} \mathrm{O}_{3} \\
& \mathrm{PuO}_{2}-\mathrm{ZrO}_{2}-\mathrm{Er}_{2} \mathrm{O}_{3} \\
& \mathrm{PuO}_{2}-\mathrm{ZrO}_{2}-\mathrm{Eu}_{2} \mathrm{O}_{3}
\end{aligned}
$$

\begin{abstract}
Although the plutonia-thoria based fuels $\left(\mathrm{PuO}_{2}-\mathrm{ZrO}_{2}-\mathrm{ThO}_{2}, \mathrm{PuO}_{2}-\mathrm{ThO}_{2}\right.$, and $\mathrm{PuO}_{2}-\mathrm{ThO}_{2}$ $\mathrm{Gd}_{2} \mathrm{O}_{3}$ ) exhibited excellent neutronic behavior comparable to that of commercial $\mathrm{UO}_{2}$ fuel, irradiation of the thorium $\left({ }^{232} \mathrm{Th}\right.$ ) results in the generation of fissile uranium ( ${ }^{233} \mathrm{U}$ ). Production of another fissile isotope was deemed unacceptable since the goal was to destroy the fissile weaponsgrade plutonium and not simply to convert one potential weapons material into another nor try to extend the fuel cycle length. Therefore, the use of thoria was ruled out as an additive for non-fertile fuels.
\end{abstract}

The $\mathrm{PuO}_{2}-\mathrm{ZrO}_{2}$ fuel form was extremely reactive in light water, which limited the fuel rod plutonia mass loadings to such low levels that the overmoderated fuel lattice tended to burnout prematurely and possessed both prompt Doppler and isothermal temperature coefficients that were positive. The solution was the addition of a burnable thermal and resonant parasitic absorber poison to the fuel composition in order to correct these deficiencies. Rare-earth elements were chosen as candidates for the poison.

Three rare-earth poison fuel compositions were neutronically evaluated, and of these, the most attractive composition was the $\mathrm{PuO}_{2}-\mathrm{ZrO}_{2}-\mathrm{Er}_{2} \mathrm{O}_{3}$. Therefore, the $\mathrm{PuO}_{2}-\mathrm{ZrO}_{2}-\mathrm{CaO}-\mathrm{Er}_{2} \mathrm{O}_{3}$ fuel composition was adopted for the BWR study here, and is the focus of more detailed analyses. Our BWR non-fertile fuel concept is shown in Figure 1 along with a brief description of some of the concept's attractive features. Figure 2 shows a cross sectional view of the infinite ABWR lattice along with the fuel pellet, gap, and clad radii and the lattice pitch dimensions used in the calculations. 


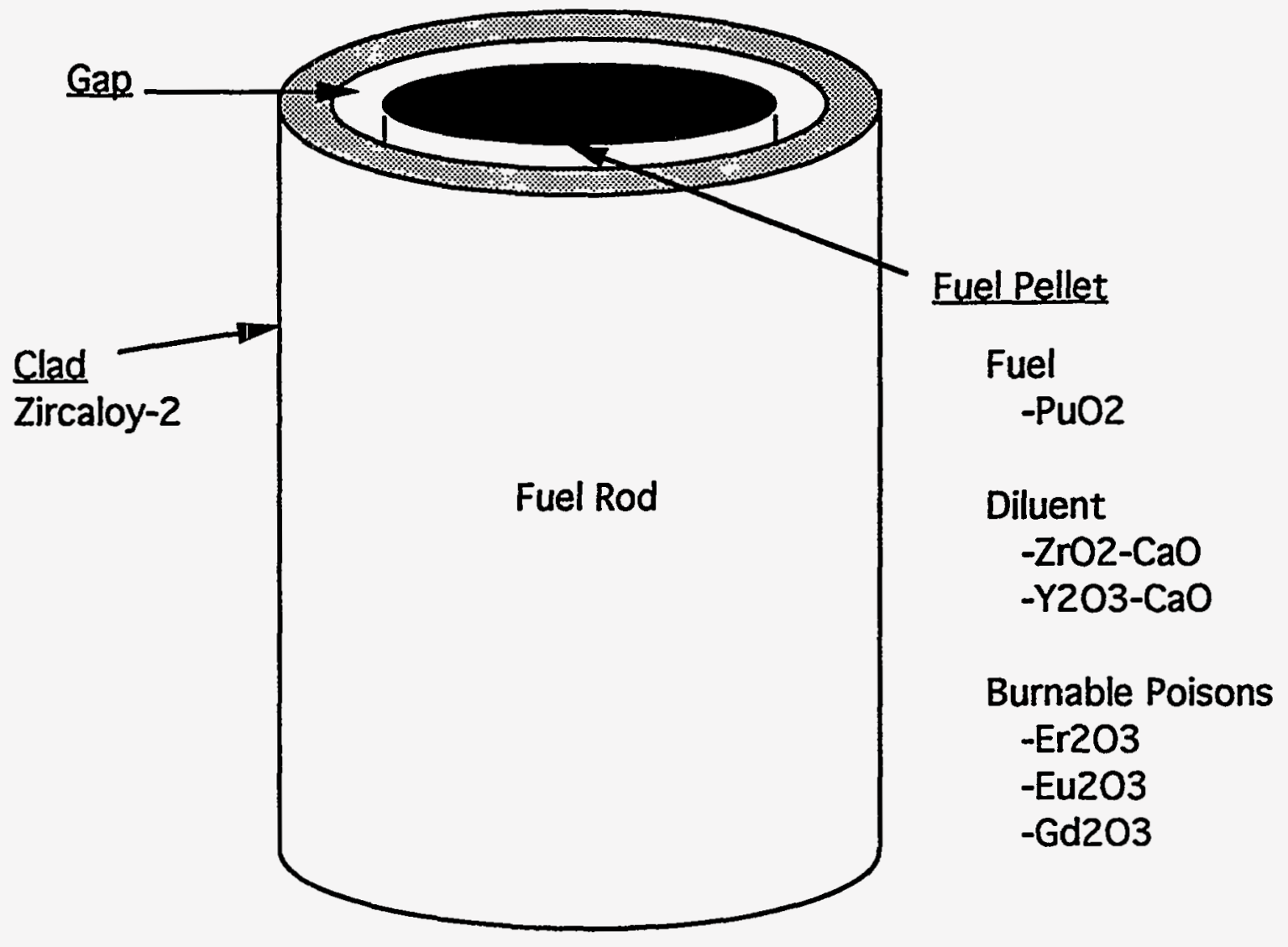

Fuel Form Characteristics

- Non-fertile, weapons-grade plutonium-based oxide

- Inert Diluent

- Burnable Poison (improve Doppler, hold down excess reactivity, heavier Pu rod loadings, extended burnup)

\section{Attractive Features}

- All Oxide Fuel (Small VF PuO2 and Er203)

- UO2-ZrO2-CaO well known fuel form

- Plutonium metal (Weapons- or Reactor-grade)

- UO2 Core Compatibility (commercial BWR reactors)

- High Pu Burnup

Figure 1. Non-fertile fuel concept for a Boiling Water Reactor. 


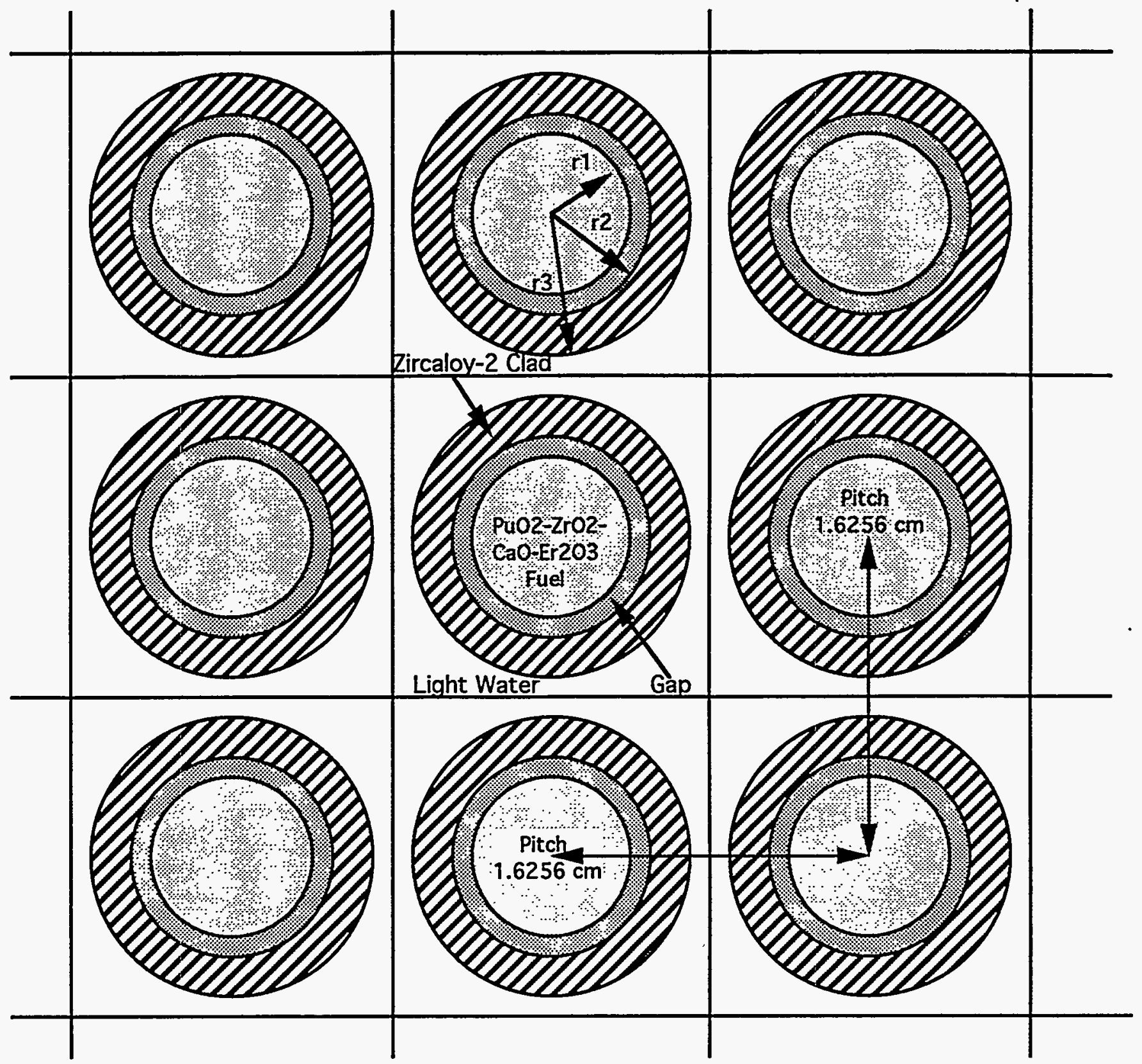

$\mathrm{r} 1=0.52197 \mathrm{~cm}$ (Pellet radius)

$\mathrm{r} 2=0.53213 \mathrm{~cm}$ (Gap radius)

$\mathrm{r} 3=0.61341 \mathrm{~cm}$ (Clad radius)

Lattice Pitch $=1.6256 \mathrm{~cm}$

Figure 2. ABWR lattice geometry and dimensions. 
The evaluation of our non-fertile fuel in a BWR environment attempts to go a step further than the previous PWR study in order to broaden the scope and applicability of the fuel concept to both types of current commercial Light Water Reactors (LWRs). Detailed BWR burnup calculations are performed in this study which were not performed in the PWR study. BWR fuel burnups are performed for the 0,40 and $70 \%$ moderator steam void conditions and two linear rod power levels typical in a BWR. BWR burnup calculations for the $0 \%$ steam void condition herein would be most applicable to the PWR for estimation of percent destruction of plutonium over the fuel burnup lifetime.

The primary goal in the development of our non-fertile, plutonium-based nuclear reactor fuel is the efficient destruction of weapons-grade plutonium in Light Water Reactors (LWRs). Although the current concern is the disposition of weapons-grade plutonium from the dismantled nuclear weapons, an even larger and ever growing stock of reactor-grade plutonium from spent commercial fuel also has to eventually be disposed of and destroyed via fission. Substitution of reactor-grade plutonium for the weapons-grade plutonium into our non-fertile fuel should exhibit even better neutronic control characteristics with burnup. The most attractive feature of a non-fertile fuel is its "deep burn" capability for once-through burnups; plutonium inventories can be substantially reduced using existing commercial LWRs. MOX fuels will denature the weapons-grade plutonium, but will destroy in a once-through cycle only $25-33 \%$ of the total plutonium isotopes, whereas, the non-fertile fuel can achieve upwards of $70 \%$ total plutonium destruction.

In order to maximize the plutonium destruction rate, a non-fertile fuel by design excludes uranium from the fuel composition. The fertile ${ }^{238} \mathrm{U}$ isotope is responsible for the production of more plutonium during burnup, particularly in natural, low, and medium-enriched uranium fuels, and in mixed oxide $(\mathrm{MOX})$ fuels. In the standard commercial $\mathrm{UO}_{2}$ fuel, the ${ }^{238} \mathrm{U}$ transmutes during burnup to $239 \mathrm{Pu}$ to provide additional fuel and reactivity for fuel cycle extension and in addition provides the necessary prompt temperature feedback reactivity in the fuel, which is essential for safe reactor operation and control.

A weapons-grade plutonium fuel can be expected to have a smaller negative Doppler temperature coefficient of reactivity relative to commercial $\mathrm{UO}_{2}$ fuel. Weapons-grade plutonium is enriched in ${ }^{239} \mathrm{Pu}$ and contains no $238 \mathrm{U}$ and only a relatively small amount of fertile $240 \mathrm{Pu}$. Hence due to mutual temperature broadening of the ${ }^{239} \mathrm{Pu}$ fission and capture resonances, the negative reactivity effect becomes small. In fact, the prompt fuel Doppler temperature coefficient of reactivity is still negative as we shall see in later sections of this report on the $\mathrm{PuO}_{2}-\mathrm{ZrO}_{2}-\mathrm{CaO}$ fuel. Fortunately, the Doppler coefficients can be designed to be more negative with the addition of the parasitic resonant absorber poison.

From our previous study ${ }^{2}$, the burnable poison erbium with its six natural isotopes, and specifically the two isotopes, ${ }^{166} \mathrm{Er}$ and ${ }^{167} \mathrm{Er}$, with their strategic thermal resonances relative to the $0.3 \mathrm{eV}$ ${ }^{239} \mathrm{Pu}$ resonance, turned out to be the leading candidate as a replacement for ${ }^{238} \mathrm{U}$. Natural erbia is an oxide which can be homogeneously and integrally mixed into the $\mathrm{PuO}_{2}-\mathrm{ZrO}_{2}-\mathrm{CaO}$ fuel composition. In addition to erbium's attractive resonance absorption ability that can increase the fuel Doppler coefficient over the burnup cycle, erbium's thermal absorption allows for plutonium mass loadings sufficient for LWR fuel cycle lengths, and ensures the fuel assembly lattice will maintain an undermoderated condition over the fuel cycle. Erbium is also a burnable poison that burns out relatively rapidly to provide letdown reactivity that helps to maximize plutonium burnup and at the same time allows for both $240 \mathrm{Pu}$ and fission products to build into the fuel in order to contribute to the Doppler coefficient. The relatively small thermal absorption cross section of erbium isotopes relative to other stronger burnable poison absorbers (e.g. gadolinium) allows the pellet radial power distribution to be relatively flat and comparable to $\mathrm{UO}_{2}$. Also, the presence of erbium in the fuel is expected to increase the negative magnitude of the isothermal temperature 
coefficient, particularly in the lower core region of a BWR where the moderator is in the unvoided liquid phase with a density similar to that in a PWR core.

The high reactivity of weapons-grade plutonium metal in a fuel rod immersed in light water requires relatively small mass quantities of the heavy metal to meet reactivity requirements. For example, only 132 grams of weapons-grade plutonium heavy metal per ABWR fuel rod are needed to achieve 1200 EFPD at $6.0 \mathrm{~kW} / \mathrm{ft}$ (ABWR fuel rod with a $12.5 \mathrm{ft}$ length and 0.411 in diameter). The $1200 \mathrm{EFPD}$ at $6.0 \mathrm{~kW} / \mathrm{ft}$ translates into a fuel fission density at EOL of approximately 7.45 * $10^{20} \mathrm{f} / \mathrm{cc}$ which is roughly equivalent to a $30 \mathrm{GWD} / \mathrm{MT}$ burnup for commercial $\mathrm{UO}_{2}$ fuel. Therefore, since only a small amount of plutonia (by weight or volume) will be required in the fuel rod composition, the bulk of the fuel pellet material composition will be diluent ( $\sim 95 \mathrm{vol} \%)$.

Selection of our diluent $\left(\mathrm{ZrO}_{2}-\mathrm{CaO}\right)$ is based on three primary concerns: (1) low thermal neutron absorption, (2) in-pile thermo-mechanical performance, and (3) previous developmental and performance experience.

Low parasitic thermal neutron absorption by the diluent nuclides is important in order to reduce the required excess reactivity necessary to overcome the clad parasitic absorption and maintain fuel assembly criticality. The lower the parasitic absorption in the fuel (and the clad), the longer the fuel assembly can remain critical near EOL, which ultimately translates into greater plutonium destruction over the fuel cycle. In addition, lower excess reactivity requirements at BOL means lower initial plutonium assembly mass loadings which in turn reduces the concern of diversion and proliferation.

The diluent thermo-mechanical behavior must exhibit crystalline stability under in-pile exposure, dimensional stability, minimal swelling due to fission product gases, acceptable fission gas release, sufficient thermal conductivity, minimal pellet-clad interaction, and retention of initial void porosity under in-pile exposure. Current commercial fuel $\left(\mathrm{UO}_{2}\right)$ performs favorably in each of these categories and is the standard upon which our new non-fertile fuel forms will ultimately be compared and evaluated.

Diluents, such as alumina $\left(\mathrm{Al}_{2} \mathrm{O}_{3}\right)$, beryllia $(\mathrm{BeO})$, and zirconia $\left(\mathrm{ZrO}_{2}\right)$ have been previously proposed and tested for different reactor applications. All three diluents have relatively small neutron absorption cross sections, but vary significantly in their material properties. Recently, $\mathrm{Al}_{2} \mathrm{O}_{3}$ has been proposed as a possible diluent for non-fertile fuels ${ }^{3,4}$. However, despite alumina's favorable phase, chemical, and thermal conductivity properties and its crystalline stability under irradiation by neutrons, alumina mixed with a fissionable material such as $\mathrm{UO}_{2}$ exhibits severe crystalline instability under in-pile irradiation. Previous in-pile experiments ${ }^{5,6}$ involving $\mathrm{UO}_{2}$ $\mathrm{Al}_{2} \mathrm{O}_{3}$ fuel indicates gross swelling (30\%vol) of the $\mathrm{Al}_{2} \mathrm{O}_{3}$ crystal structure at low burnups. Apparently, the fission fragment recoil kinetic energy destroys the $\mathrm{Al}_{2} \mathrm{O}_{3}$ crystal lattice and converts it into a reduced-density amorphous structure. The $\mathrm{BeO}$ matrix in a $\mathrm{UO}_{2}-\mathrm{BeO}$ fuel ${ }^{5,6,7}$ also suffers from considerable fission fragment damage and exhibits high swelling and gas release.

Previous in-pile experimental and irradiation data demonstrate $\mathrm{ZrO}_{2}$ to be a viable diluent when stabilized with $\mathrm{CaO}$. The unstabilized $\mathrm{ZrO}_{2}$ diluent by itself does not exhibit ideal diluent fuel material characteristics. For example, an unirradiated $\mathrm{UO}_{2}-\mathrm{ZrO}_{2}$ fuel with a two-phase tetragonal structure upon irradiation under goes rapid densification or void collapse due to the high plasticity from phase instability $8,9,10$. The plasticity results from the crystalline structure transformations as a function of burnup. The unirradiated two phase tetragonal structure transforms into a single tetragonal structure at an exposure of $5.8 * 10^{20} \mathrm{f} / \mathrm{cc}$ and then to a single phase cubic structure at an exposure of $9.0 * 10^{20} \mathrm{f} / \mathrm{cc}$. Basically, the non-cubic crystalline phases convert from their tetragonal or monoclinic phases to a cubic phase during irradiation. In order to control the phase transformations and plasticity, small amounts of $\mathrm{CaO}$ are added to the $\mathrm{UO}_{2}-\mathrm{ZrO}_{2}$ fuel to form an 
unirradiated cubic crystalline structure that is stable under irradiation conditions resulting in minimal dimensional changes (no densification) and retention of initial porosity with bumup. The $\mathrm{UO}_{2}-\mathrm{ZrO}_{2}-\mathrm{CaO}$ cubic structure is then similar to the face-centered cubic structure of $\mathrm{UO}_{2}$.

The choice of zirconia $\left(\mathrm{ZrO}_{2}\right)$ stabilized with calcia $(\mathrm{CaO})$ as our diluent is also based on the substantial developmental and experimental data base supporting both urania-zirconia-calcia (ternary) fuel forms and urania-zirconia (binary) fuel forms from previous programs ${ }^{7}$. Major ternary fuel development programs include the following:

(1) The Shippingport PWR Core 2, Seed 2 utilized a ternary fuel consisting of 38wt\% $\mathrm{UO}_{2}-57 \mathrm{wt}_{2} \% \mathrm{ZrO}_{2}-5 \mathrm{wt} \% \mathrm{CaO}$ fuel plates with Zircaloy cladding. From 1969-1974, the Shippingport ternary fuel composition achieved average and local peak burnups of 17 * $10^{20}$ and $27 * 10^{20} \mathrm{f} / \mathrm{cc}$, respectively, without fuel failure.

(2) The Power Burst Facility (PBF) at the Idaho National Engineering Laboratory utilized a ternary fuel consisting of $30.6 \mathrm{wt} \% \mathrm{UO}_{2}-62.5 \mathrm{wt} \% \mathrm{ZrO}_{2}-6.9 \mathrm{wt} \% \mathrm{CaO}$ fuel rods in stainless steel clad7,8. Transient power tests exposed the insulated fuel to 50-200 power bursts and temperatures up to $2150 \mathrm{C}$. The ternary fuel performed with no rod failures, fuel melt did occur as predicted at the rod centerline. The peak fuel burnup is estimated at only $1.3 *$ $10^{19} \mathrm{f} / \mathrm{cc}$.

(3) The Light Water Breeder Reactor (LWBR) program used and tested an experimental ternary fuel consisting of $36.9 \mathrm{wt} \% \mathrm{UO}_{2}-58.1 \mathrm{wt} \% \mathrm{ZrO}_{2}-5 \mathrm{wt} \% \mathrm{CaO}$ duplex fuel pellets along with $\mathrm{UO}_{2}$ and $\mathrm{UO}_{2}-66$ wt\% $\mathrm{ZrO}_{2}$ duplex pellets. Both $\mathrm{UO}_{2}$ and ternary duplex fuel were successfully irradiated to high burnup $\left(30 * 10^{20} \mathrm{f} / \mathrm{cc}\right)$.

Reference 7 provides a more detailed description of each program and other smaller in-pile tests using ternary fuel tests.

An important aspect in the development of a new fuel concept like the non-fertile fuel concept here is the existence of a developmental and experimental data base from previous programs. Without a pertinent data base the fuel fabrication and performance risks are greatly increased particularly if the fuel development program embarks on an aggressive schedule.

The National Academy of Sciences Committee on International Security and Arms Control (NASCISAC) Reactor panel has already expressed this concern with non-fertile fuel development in their recommendations to Congress ${ }^{11}$. The NAS envisioned a non-fertile fuel development program to be a potentially lengthy and risky process to qualify/certify a new reactor fuel and therefore would probably not meet an aggressive disposition schedule. In our case, however, with the sizeable data base available on the urania ternary fuels, a non-fertile fuel development program might be more comparable to the fuel development program for weapons-grade plutonium MOX.

Although a literature search has revealed no previous fabrication or irradiation testing of a $\mathrm{PuO}_{2}$ $\mathrm{ZrO}_{2}-\mathrm{CaO}$ ternary fuel, the chemical and material properties and fuel performance of such a fuel should be similar to the $\mathrm{UO}_{2}-\mathrm{ZrO}_{2}-\mathrm{CaO}$ ternary fuel. Substitution of weapons-grade plutonia for low- or medium-enriched urania in this ternary fuel leads directly to a lower weight percent of plutonium versus uranium metal simply because of the more reactive nature of plutonium. This is evidenced by the approximately $8.0 \mathrm{wt} \%$ plutonia in our fuel composition versus the 30-50 wt\% urania used in the ternary fuel development programs mentioned above. This difference may 
present some advantages for the plutonium ternary fuel versus the uranium ternary fuel, namely, slight improvement in the thermal conductivity and greater crystalline stability. Also, since the zirconia-calcia content is increased (approximated $85 \mathrm{vol} \%$ in our adopted fuel composition) there will be more porous volume available throughout the pellet for fission gas expansion. The result will be lower fuel centerline temperatures and reduced fuel swelling and possibly less fission gas release for the $\mathrm{PuO}_{2}-\mathrm{ZrO}_{2}-\mathrm{CaO}$ versus the $\mathrm{UO}_{2}-\mathrm{ZrO}_{2}-\mathrm{CaO}$ ternary fuels.

The thermal conductivity of the plutonium ternary fuel is, however, still expected to be roughly onehalf of the thermal conductivity of $\mathrm{UO}_{2}$ at operating temperatures 1 . The lower conductivity would result in higher fuel centerline temperatures for the ternary fuels relative to a $\mathrm{UO}_{2}$ fuel assuming comparable linear heat generation rates and heat transfer coefficients. Also, the melting point of a $\mathrm{ZrO}_{2}-\mathrm{CaO}(15 \mathrm{at} \% \mathrm{CaO})$ diluent is in the range of $2450-2600^{\circ} \mathrm{C}$ and a $\mathrm{UO}_{2}(14.4 \mathrm{wt} \%)-\mathrm{ZrO}_{2}(77.1$ wt\%)-CaO $(8.5 \mathrm{wt} \%)$ ternary fuel (which is comparable to our plutonium ternary fuel compositions) has a melting point ${ }^{7}$ of $2670^{\circ} \mathrm{C}$. These melting points are lower than the melting point ${ }^{7}$ of $^{\mathrm{UO}_{2}}$ at approximately $2800^{\circ} \mathrm{C}$. If the solid plutonia ternary fuel rod centerline temperatures become a concern, i.e. the margin between the operational/accident centerline fuel temperatures and the fuel melting point is too small, the use of an annular fuel pellet would be the ready solution.

A great deal of annular fuel test data is available for both $\mathrm{UO}_{2}$ and ternary fuels 7 . An annular pellet would provide even greater fission gas volume for further reduction in fuel swelling and could potentially reduce the maximum fuel temperatures by up $400^{\circ} \mathrm{C}$ or more.

Another potential fuel performance enhancement option for the non-fertile $\mathrm{PuO}_{2}-\mathrm{ZrO}_{2}-\mathrm{CaO}_{-} \mathrm{Er}_{2} \mathrm{O}_{3}$ fuel composition is a proposed substitution of the diluent stabilizing agent yttria $\left(\mathrm{Y}_{2} \mathrm{O}_{3}\right)$ for calcia $(\mathrm{CaO})$. The companion LDRD ${ }^{1}$ explores the possible benefits of using yttria to form a fuel composition of $\mathrm{PuO}_{2}-\mathrm{ZrO}_{2}-\mathrm{Y}_{2} \mathrm{O}_{3}-\mathrm{Er}_{2} \mathrm{O}_{3}$. Yttria, like calcia, is also neutronically inert and is demonstrated in the neutronic results of this study.

The following sections of the report present the calculated neutronic results for both a $\mathrm{PuO}_{2}-\mathrm{ZrO}_{2}$ $\mathrm{CaO}$ and $\mathrm{a} \mathrm{PuO}_{2}-\mathrm{ZrO}_{2}-\mathrm{CaO}-\mathrm{Er}_{2} \mathrm{O}_{3}$ fuel composition in a $\mathrm{BWR}$ operating environment using lattice dimensions based on the 8x8 General Electric Advanced Boiling Water Reactor ${ }^{12}$ fuel assembly. In the neutronic analysis here, the fuel rod is assumed to operate at a steady-state conditions and at a constant linear heat generation rate (LHGR). 


\subsection{ASSUMPTIONS}

The following assumptions and bases are used in the neutronic calculations:

- Evaluated Nuclear Data File Version 5 (ENDF/B-V) and Version 6 (ENDF/B-VI).

- Neutronic models are based on a GE 8x8 commercial Advanced Boiling Water Reactor (ABWR) fuel assembly dimensions ${ }^{12}$.

- The effects of fuel and clad thermal expansion are not included in the neutronic calculations.

- Clad material is Zicaloy-2.

- Weapons-grade isotopic plutonium weight percentages used in the BOL neutronic calculations are from References 13 and 14 as given below:

$$
\begin{array}{ll}
0.012 \text { wt\% } & 238 \mathrm{Pu} \\
93.81 \text { wt\% } & 239 \mathrm{Pu} \\
5.810 \text { wt\% } & 240 \mathrm{Pu} \\
0.349 w t \% & 241 \mathrm{Pu} \\
0.022 \text { wt\% } & 242 \mathrm{Pu}
\end{array}
$$

- Isotope molecular weights are from Reference 15.

- Material densities are from References 16 and 17.

- Ratio of $\mathrm{ZrO}_{2}$ to $\mathrm{CaO}$ is based on References 18 and 19.

- Saturated liquid water densities at ABWR pressure (1050 psig) and saturated temperature conditions are based on References 12 and 20. 


\subsection{COMPUTER CODES}

The neutronic analyses use six different reactor physics computer codes to perform calculations on our non-fertile fuel compositions. Each of the six codes is briefly described below:

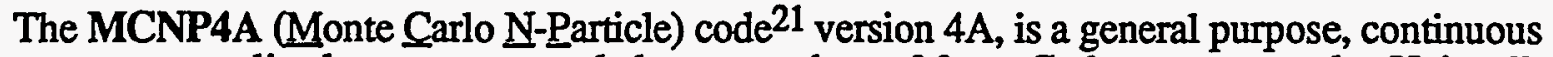
energy, generalized geometry, coupled neutron-photon Monte Carlo transport code. Unit cell models with reflective boundary conditions are constructed in MCNP geometry format to represent an infinite lattice for k-infinity determinations and cross section generation.

The COMBINE-5 \& COMBINE-6 codes $^{22,23}$ are 166-multigroup deterministic neutron spectrum codes based on the $\mathrm{B}_{\mathrm{N}}$ approximation to the Boltzman transport equation. Solution methodology options include the Nordheim method for resolved resonance shielding and the ABH method for unit cell thermal self shielding. Unit cell $\mathrm{k}$-infinities are calculated as a function of temperature to determine the prompt fuel Doppler and isothermal temperature coefficients of reactivity. The COMBINE-5 code employs the ENDF/B-V nuclear data and COMBINE-6 employs the ENDF/BVI nuclear data.

The ORIGEN2 code 24 is a zero-dimensional, one-group code for calculating the buildup, decay, and processing of radioactive materials. The code is specifically used to perform plutonium fuel depletion calculations in order to determine approximate plutonium burnup and isotopic content in a fuel composition at specified points in the burnup cycle.

The MOCUP code 25 is a system of external processors that links input and output files from MCNP4A and ORIGEN2 in order to perform a time-dependent burnup of a fuel composition. Neutron cross sections are calculated by MCNP at the start of each time step for each of the designated nuclides in the fuel composition. MOCUP transfers the cross sections to an ORIGEN2 input file. ORIGEN2 then performs the burnup calculation and MOCUP builds a new MCNP file based on the old MCNP input file and the ORIGEN2 output fuel nuclide concentrations. MCNP calculates the lattice $k_{\text {inf }}$ and generates cross sections for the next time step and the process begins anew.

The NJOY code 26,27 was used to produce point-wise neutron cross sections from ENDF/B-VI evaluated nuclear data for use by the MCNP code. Neutron cross section evaluations were obtained for certain nuclides and isotopes at elevated temperatures that were not available in the standard libraries. 


\subsection{NEUTRON CROSS SECTION DEVELOPMENT}

MCNP continuous energy neutron cross section libraries had to be developed for the plutonium isotopes and rare-earth burnable poisons used in this study. The NJOY nuclear data processing code, version 91.91, was used to process the ENDF/B-VI cross section data into the MCNP continuous energy ACE format. The NJOY modules, RECONR, BROADR, UNRESR, and HEATR were used to reconstruct the resonance cross sections from their resonance parameters and determine a single linearized energy grid for all reactions, broaden the resonance data to the appropriate temperature and thin the data, compute the unresolved resonance cross section contributions at temperature, and calculate the heating and radiation damage production. After these steps, the ACER module was run to convert the data to the MCNP continuous-energy format. The ACER module also thins the data using an integral thinning method. Appendix B has a list of nuclides/isotopes for which specific cross section libraries at temperature were developed and samples of neutron cross sections as a function of energy for a few selected isotopes. 


\subsection{METHODOLOGY}

The following three sections describe briefly selected areas of the methodology that might be most useful to the interested reader. These areas include model representations and simplifications and some of the analytical procedure used in the newly available burnup capability using the MOCUP code.

\subsection{MCNP Unit Cell Model Description}

For simplicity, the boiling water nuclear reactor core of fuel assemblies and control rods are represented in the models as an infinite array of fuel rods with no control rods or other neutron absorbing material in the fuel lattice. The infinite lattice geometry chosen for the models is essentially an uncontrolled infinite fuel lattice. The assumption is that the control rods will compensate for the excess reactivity.

The MCNP neutronic calculations use a two-dimensional unit cell model with dimensions based on the commercial GE 8x8 Advanced Boiling Water Reactor fuel assembly. The unit cell is described by a central cylindrical fuel rod, gap, clad, and an encompassing square water region as shown on Figure 2. In order to represent an infinite lattice of these unit cells, mirror boundaries are applied to all four sides of the square water region and on top and bottom of the $12.5 \mathrm{ft}$. long unit cell. The mirror boundaries on the top and bottom are only slightly more reactive and easier to model than a more accurate water reflector region above and below the fuel rod ends and should not significantly impact the result herein.

The fuel rod composition is a mixture of weapons-grade plutonia $\left(\mathrm{PuO}_{2}\right)$, zirconia $\left(\mathrm{ZrO}_{2}\right)$, and calcia $(\mathrm{CaO})$. The zirconia and calcia are the diluent and make up the bulk of our fuel rod material. A burnable poison, erbia $\left(\mathrm{Er}_{2} \mathrm{O}_{3}\right)$, is added in small mass quantities to the fuel composition in order to improve the prompt Doppler coefficient of reactivity, maximize plutonium burnup, produce a negative isothermal temperature coefficient of reactivity, and provide hold down reactivity at BOL. The fuel gap is assumed to be a void, the cladding is Zircaloy-2 metal, and the moderator/coolant is light water $\left(\mathrm{H}_{2} \mathrm{O}\right)$.

The hot operational conditions assume the fuel to be at $2153 \mathrm{~K}\left(\sim 3400^{\circ} \mathrm{F}\right)$, the clad at $880 \mathrm{~K}$ $\left(-1125^{\circ} \mathrm{F}\right)$, and the moderator light water temperature of $600 \mathrm{~K}\left(\sim 620^{\circ} \mathrm{F}\right)$. The fuel temperature is slightly higher than the maximum fuel temperature 28 of approximately $2100 \mathrm{~K}$ which is characteristic of a typical BWR/6 with low-enriched $\mathrm{UO}_{2}$ fuel. However, because the thermal conductivity of the $\mathrm{PuO}_{2}-\mathrm{ZrO}_{2}-\mathrm{CaO}-\mathrm{Er}_{2} \mathrm{O}_{3}$ fuel is expected to be only slightly more than one-half of $\mathrm{UO}_{2}$, the higher $2153 \mathrm{~K}$ temperature seemed reasonable. The moderator temperature at $600 \mathrm{~K}$ is also higher than the approximately $550^{\circ} \mathrm{F}$ saturated temperature in a BWR, however, we were bound by the available $S(\alpha, \beta)$ cross section data at 500 or $600 \mathrm{~K}$, and the $600 \mathrm{~K}$ cross section set was chosen.

Several neutronic calculations vary the fuel assembly pitch to determine if the lattice with a particular fuel composition is undermoderated or overmoderated. However, unless the pitch is specifically varied, all calculations are based on a fuel rod center-to-center pitch of $1.6256 \mathrm{~cm}(0.64$ in.) characteristic of the ABWR lattice.

The BWR moderator liquid water density varies as a function of core height. In order to model the axial variation in density, selected enveloping moderator steam voids were chosen as evaluation points, namely, 0,40 , and $70 \%$. These moderator steam void conditions are chosen to represent the lower, mid, and upper core, respectively. The $40 \%$ steam void is also used in some calculations to represent an average BWR core moderator density. In all cases, steam is simply represented as void. 
The MCNP code and input models are used to calculate the hot and cold lattice k-infinity for prediction of the fuel lattice moderation conditions as a function of lattice pitch, steam void coefficients of reactivity, erbia poison concentrations, and fuel lattice criticality as a function of burnup. In addition, MCNP was used to calculate the fuel pellet radial power distributions and cross sections for the ORIGEN2 burnup calculations.

\subsection{COMBINE Pin Cell Model Description}

The COMBINE-5 and COMBINE- 6 calculations both use a one-dimensional infinite cylindrical pin cell model with dimensions also based on the commercial GE 8x8 ABWR fuel assembly. The pin cell model is similar to the MCNP unit cell model, except the moderator region is represented geometrically by a volume-equivalent cylindrical annulus around the clad instead of a square region.

The COMBINE-5 and COMBINE-6 codes and input models were used primarily to calculate the fuel Doppler coefficients and lattice isothermal temperature coefficients as a function of burnup. One-group cross section comparisons between COMBINE-5/COMBINE-6 and MCNP were also performed to ensure some correspondence between the two different calculational techniques. Cross section comparisons are in excellent agreement, although no results will be given in this document.

\subsection{Burnup Calculations}

Constant power rod burnup calculations are performed with the ORIGEN2 computer code. The lumped fuel rod mass is assumed to produce via fission a constant and continuous thermal power output over each burnup increment and throughout the fuel burnup lifetime. The constant rod power outputs chosen are 75.0 and $150.0 \mathrm{~kW} / \mathrm{rod}$ or 6.0 and $12.0 \mathrm{~kW} / \mathrm{ft}$ LHGRs, respectively. The $6.0 \mathrm{~kW} / \mathrm{ft}$ LHGR represents an average value for the ABWR core as a whole; the $12.0 \mathrm{~kW} / \mathrm{ft}$ LHGR is simply the average doubled. Since the ABWR has a $14.4 \mathrm{~kW} / \mathrm{ft}$ LHGR upper limit, the $12.0 \mathrm{~kW} / \mathrm{ft}$ rate is a conceivable operating rate. The burnup calculations are based on continuous effective full power days (EFPD) of rod power output and do not make provision for plant operation or an assigned capacity factor (CF).

In order to initially estimate the required plutonia fuel rod loading for a 3-year burnup, two assumptions had to be made: (1) $6.0 \mathrm{~kW} / \mathrm{ft}$ LHGR and (2) $100 \%$ burnup of all the plutonium. For the $\mathrm{PuO}_{2}-\mathrm{ZrO}_{2}-\mathrm{CaO}$ fuel rod composition, $1080 \mathrm{EFPD}(36$ months) at $6.0 \mathrm{~kW} / \mathrm{ft}$ power output was chosen initially, which translated into a $5.69 \mathrm{wt} \% \mathrm{PuO}_{2}$ fuel loading for our non-fertile fuel composition with no burnable poison.

A series of preliminary burnup calculations using the $5.69 \mathrm{wt} \% \mathrm{PuO}_{2}$ in the fuel composition was run with variation in the LHGR, moderator steam void, and erbia concentration. In order to maintain the fuel rod criticality ( $k_{\text {inf }} \geq 1.0$ ) for a period of up to $1080 \mathrm{EFPD}$, the $\mathrm{PuO}_{2}$ concentration in the fuel had to be increased to approximately $8.41 \mathrm{wt} \%$. This higher concentration allowed the fuel rod to remain critical over the range of 500-1200 EFPD for the 12.0 and $6.0 \mathrm{~kW} / \mathrm{ft}$ LHGRs and the 0,40 , and $70 \%$ moderator steam void conditions. Burnup calculations were then run exclusively with the heavy metal rod mass loading corresponding to the $8.41 \mathrm{wt} \% \mathrm{PuO}_{2}$ concentration in the $\mathrm{PuO}_{2}-\mathrm{ZrO}_{2}-\mathrm{CaO}-\mathrm{Er}_{2} \mathrm{O}_{3}$ fuel composition.

In this study, the point at which the fuel rod goes subcritical $(\mathrm{k}$-infinity $\leq 1.0)$ is the designated point in EFPD at which plutonium burning is deemed complete (note: with a checkerboard arrangement of high and low (burned up) reactivity fuel assemblies, high reactivity assemblies could drive subcritical assemblies to higher burnups). Therefore, it is important to ensure that the fuel rod reactivity is accounted for accurately at each time step over the burnup period. Two key parametric 
Table 1. List of the fuel nuclides/isotopes whose neutron cross sections are updated with each burnup time step.

\begin{tabular}{|c|c|}
\hline NUCLIDE CATEGORY & NUCLIDES \\
\hline Plutonium & ${ }^{238} \mathrm{Pu},{ }^{239} \mathrm{Pu},{ }^{240} \mathrm{Pu},{ }^{241} \mathrm{Pu},{ }^{242} \mathrm{Pu}$ \\
\hline Higher Actinides & ${ }^{241} \mathrm{Am},{ }^{243} \mathrm{Am},{ }^{242} \mathrm{Cm},{ }^{244} \mathrm{Cm}$ \\
\hline Burnable Poisons & ${ }^{166} \mathrm{Er},{ }^{167} \mathrm{Er}$ \\
\hline Fission Products & 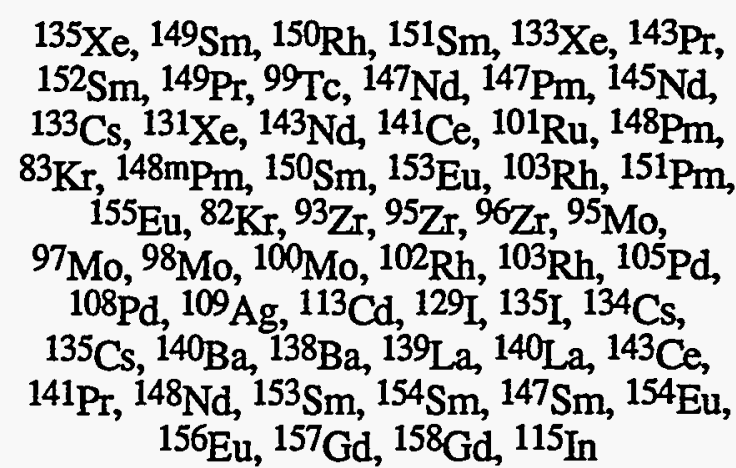 \\
\hline
\end{tabular}


areas of sensitivity to the fuel rod reactivity are: (1) the number of higher-order actinides and fission product poison nuclides/isotopes that are included in the fuel rod inventory and (2) neutron cross section variation with burnup.

In order to determine how many higher-order actinide and fission product nuclides/isotopes were required for the calculations, preliminary studies increased the number of higher-order actinides and fission product nuclides until the $k_{\text {inf }}$ value converged. The final number of nuclides/isotopes that correspond to a converged lattice $k_{\text {inf }}$ is given in Table 1 . Cross sections are calculated at each time step for all 69 different nuclides: 5 plutonium isotopes, 4 higher-order actinide nuclides/isotopes, 2 burnable erbium poison isotopes, and 58 different fission product nuclides/isotopes. The concentration of the diluent nuclides, namely, zirconium, calcium, and oxygen, are assumed to remain constant in the burnup calculation, and their BOL cross sections are not updated at each time step.

In order to calculate and utilize the appropriate burnup-dependent neutron cross sections in our burnup calculations, the MCNP, ORIGEN2, and the MOCUP codes were employed. The computer intensive and time-consuming calculation involved a sequential and repetitive procedure involving these three codes. First, the MCNP code is executed in order to calculate the infinite lattice $k_{\text {inf }}$ and generate the total cell flux and reactions rates for the fission, capture, and $(n, 2 n)$ neutron cross sections for each of the plutonium isotopes, the erbium poison isotopes, and all 58 fission products in the fuel composition. Second, the total flux and reaction rates are then read and arithmetically manipulated into one-group cross sections by MOCUP and fed as input to the ORIGEN2 input file. In addition, the MCNP material card number densities are read and transferred by MOCUP to the ORIGEN2 input file. Third, the LHGR and burnup interval is selected for the ORIGEN2 input file and the burnup calculation run for the time interval duration. Fourth, nuclide concentrations in the ORIGEN2 output file are then fed back into a new updated MCNP input file by MOCUP, and the process begins anew for the next time step with the calculation of new a $k_{\text {inf }}$ value and the total cell flux and reactions rates.

Although the MCNP code is capable of calculating quite accurately one-group or multi-group cross sections, only one-group cross sections are required as input for the ORIGEN2 model. MCNP cross sections are both spectrally and spatially weighted over the fuel rod volume and are based on continuous energy neutron cross sections for the fuel, clad, and moderator nuclides.

The time interval between cross section updates is crucial to the accuracy of the burnup calculation. After preliminary testing and cross section behavior observed over the burnup cycle, the following time points in Table 2 were used to update neutron cross sections for the two different LHGRs used in the study.

Concern over the statistical error associated with the MCNP-generated one-group cross sections and the propagation of these errors through the burnup calculation is mitigated because the absolute statistical errors associated with the cross sections, particularly in the case of the fission and capture cross sections of the major fuel actinides and poisons, were quite small. Absolute errors were less than $0.5 \%$ and in most cases significantly less than $0.5 \%$. In addition, with sufficient time steps and the relatively smooth and flat behavior of the cross sections over most of the burnup (except near EOL), one would expect the statistical aberrations to be relatively insignificant and possibly cancel each other out over the course of the burnup calculation. 
Table 2. Time points over the burnup period in which neutron cross sections are calculated by MCNP and updated for the next ORIGEN2 burnup calculation.

\begin{tabular}{|c|c|}
\hline $\begin{array}{c}\text { TIME POINTS } \\
\text { for the } \begin{array}{c}\text { 6. } \mathrm{kW} / \mathrm{ft} \text { LHGR } \\
\text { (days) }\end{array}\end{array}$ & $\begin{array}{c}\text { TIME POINTS } \\
\text { for the12.0 } \mathrm{kW} / \mathrm{ft} \text { LHGR } \\
\text { (days) }\end{array}$ \\
\hline 0 & 0 \\
1 & 1 \\
50 & 50 \\
100 & 100 \\
200 & 200 \\
300 & 300 \\
400 & 400 \\
500 & 500 \\
600 & 550 \\
700 & 600 \\
800 & 650 \\
900 & \\
1000 & \\
1100 & \\
1200 & \\
1300 & \\
\hline
\end{tabular}




\subsection{NEUTRONIC EVALUATION -- $\mathrm{PuO}_{2}-\mathrm{ZrO}_{2}$-CaO FUEL}

This section presents neutronic calculational results that characterize the behavior of a plutoniaziconia-calcia $\left(\mathrm{PuO}_{2}-\mathrm{ZrO}_{2}-\mathrm{CaO}\right.$ ) fuel composition (without a burnable poison) in a boiling water reactor operational environment using the ABWR fuel assembly dimensions and pitch for the infinite lattice calculations. The $\mathrm{PuO}_{2}-\mathrm{ZrO}_{2}-\mathrm{CaO}$ fuel composition neutronic characteristics in Section 6.0 here can be compared with those of the $\mathrm{PuO}_{2}-\mathrm{ZrO}_{2}-\mathrm{CaO}-\mathrm{Er}_{2} \mathrm{O}_{3}$ fuel composition presented in Section 7.0 in order to see the improvement with the addition of the burnable erbia poison.

Burnup results in Section 6.6 are based on BOL cross sections. Hot operating conditions assume the fuel to be at $2153 \mathrm{~K}$, clad at $880 \mathrm{~K}$, and the light water moderator $600 \mathrm{~K}$ and cold conditions are assumed to be $300 \mathrm{~K}$ or room temperature.

\subsection{Undermoderated or Overmoderated Lattice}

The highly reactive nature of weapons-grade plutonium metal immersed in a light water moderator leads to relatively low BOL rod mass loadings without a burnable poison. For example, an initial 132-gram plutonium metal mass $\left(8.41 \mathrm{wt} \% \mathrm{PuO}_{2}\right)$ in a $12.5 \mathrm{ft}$ long and 0.411 in OD BWR fuel rod (without a burnable poison) will produce a $k$-infinity value of approximately 1.6 for a $40 \%$ steam void in the moderator. With these relatively low heavy metal mass loadings, questions of fuel assembly moderation arise: Is the ABWR fuel assembly under- or overmoderated over its burnup lifetime and should the ABWR pitch be modified to accommodate the non-fertile fuel rods?

Figure 3 shows the variation in $\mathrm{k}$-infinity as a function of fuel assembly lattice pitch for a range of $\mathrm{PuO}_{2}$ rod mass loadings. The MCNP-calculated k-infinity results presented on Figure 3 are for fuel, clad, and moderator at hot operating conditions with $40 \%$ moderator steam void. The selected range of mass loadings attempts to parallel the expected heavy metal loadings as a function of burnup. The ABWR pitch is also indicated on Figure 3. Table 3 below provides cross reference data between the plutonia weight percent loading in the rod and the actual grams of weapons-grade plutonium metal used in the parametric studies.

Table 3. Plutonia weight percent mass loading and corresponding weapons-grade plutonium metal per fuel rod for the $\mathrm{PuO}_{2}-\mathrm{ZrO}_{2}-\mathrm{CaO}$ fuel composition.

\begin{tabular}{|c|c|}
\hline $\begin{array}{c}\mathrm{PuO}_{2} \\
\text { (wt\%) }\end{array}$ & $\begin{array}{c}\text { Pu Metal } \\
\text { (g/rod) }\end{array}$ \\
\hline 8.41 & 132 \\
6.52 & 101 \\
5.69 & 88 \\
3.83 & 59 \\
2.89 & 44 \\
1.94 & 29 \\
0.97 & 15 \\
\hline
\end{tabular}

It is apparent from Figure 3 that the ABWR lattice is in the desired undermoderated condition for all the fuel loadings. Even the lightest loading $(0.97 \mathrm{wt} \%)$ which is at the peak of the curve could be considered undermoderated. This is implies that the fuel lattice will remain undermoderated throughout the fuel burnup lifetime and as we shall see in Section 7.4 on burnup characteristics this is the case. 


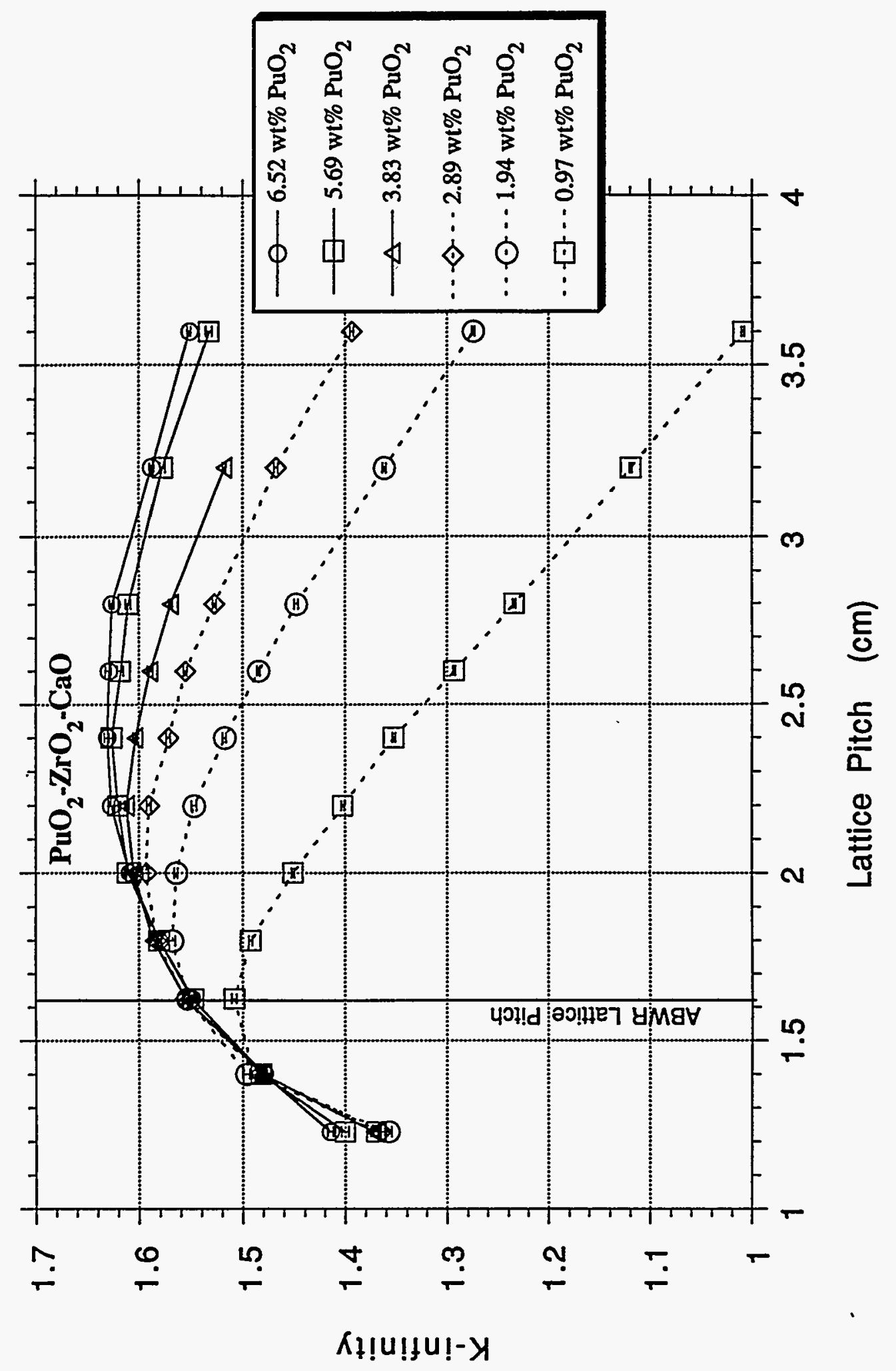

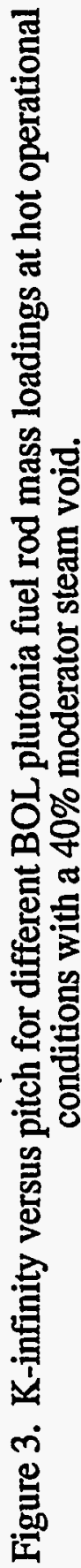


From Figure 3, it is also apparent that as the $\mathrm{PuO}_{2}$ weight percent increases, the lattice attains a greater undermoderated condition. Therefore, for a $\mathrm{PuO}_{2}$ weight percent greater than $6.52 \mathrm{wt} \%$, for example, $8.3 \mathrm{wt} \%$ which will be used in later sections in conjunction with a burnable erbia poison, it is predicted here that the lattice will remain in an undermoderated condition.

Figure 4 shows the variation in k-infinity again as a function of lattice pitch and also as a function of moderator steam void percent for both hot and cold operating conditions using a constant 5.62 wt $\% \mathrm{PuO}_{2}$ fuel loading. As expected, the lattice becomes more undermoderated as the steam void percent increases. At zero steam void for both hot $(600 \mathrm{~K})$ and cold $(300 \mathrm{~K})$ moderator temperatures, the ABWR lattice continues to remain in the undermoderated condition. These trends are expected to apply to the other $\mathrm{PuO}_{2}$ fuel mass loadings as well.

Figure 5 shows the variation of $k$-infinity as a function of the moderator steam void percent. The $\mathrm{k}$-infinity values decrease with increasing steam void percent for the ABWR pitch and a $5.69 \mathrm{wt} \%$ $\mathrm{PuO}_{2}$ fuel mass loading. This behavior is predictable from Figure 4 and desirable from a Loss-ofCoolant Accident or power excursion standpoint.

An important observation here is that the $\mathrm{ABWR}$, although designed for $\mathrm{UO}_{2}$ and $\mathrm{MOX}$ fuels, possesses the desirable undermoderated condition over a range of operating conditions for a nonfertile type fuel. In this case, the non-fertile fuel is a weapons-grade $\mathrm{PuO}_{2}-\mathrm{ZrO}_{2}-\mathrm{CaO}$ fuel. In later sections, even though the non-fertile fuel here will contain a small amount of burnable poison to hold down the excess reactivity of the weapons-grade plutonium, the basic results of this section will still apply as later verified. Selection of the ABWR fuel assembly lattice dimensions for our study of non-fertile fuels was therefore deemed acceptable.

\subsection{Steam Void Coefficient}

Based on the k-infinity data calculated by MCNP (Figure 5), the BOL steam void coefficient of reactivity can be calculated and is plotted on Figure 6 . The steam void coefficient is negative over the entire steam void range and becomes increasingly more negative as the steam void percent increases, as desired.

The steam void coefficient of reactivity is defined to be the ratio of the reactivity difference for the infinite lattice with steam void and unvoided to the steam fraction 30 . The steam fraction being the coolant channel volume occupied by steam.

\subsection{Cross Sections and Steam Void}

It is of interest to understand the variation in the plutonium isotopes' fission and absorption cross sections as a function of moderator steam void. Figure 7 shows the plutonium isotopes' one-group spectrum-averaged capture and fission cross sections as a function of moderator steam void. It is clear that the capture and fission cross sections decrease with increasing steam void. One exception is the small $240 \mathrm{Pu}$ fission cross section. The ${ }^{239} \mathrm{Pu}$ and ${ }^{241} \mathrm{Pu}$ fission cross sections decrease at a greater percentage rate than the capture cross sections and therefore account for the decrease in reactivity as a function of increasing moderator steam void (Figure 5).

Also shown on Figure 7, at zero moderator steam void, is the sharp drop in the ${ }^{239} \mathrm{Pu}$ and ${ }^{241} \mathrm{Pu}$ fission and capture cross sections and the increase in $240 \mathrm{Pu}$ capture cross section for a rise in the moderator temperature from 300 to $600 \mathrm{~K}$. The rise in moderator temperature here attempts to represent the change from cold standby to hot standby. The resulting change in reactivity results in a desirable negative reactivity feedback. 


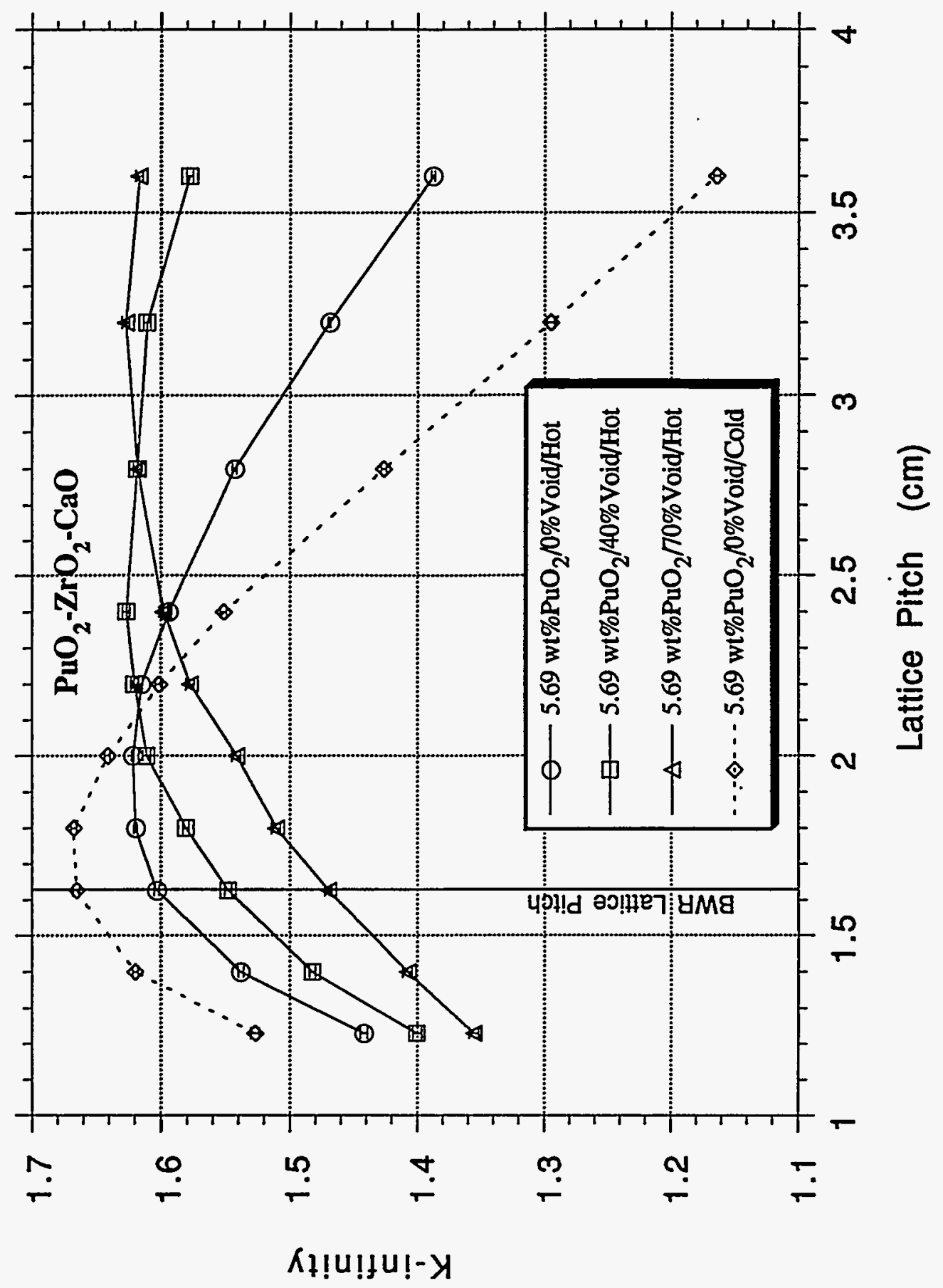

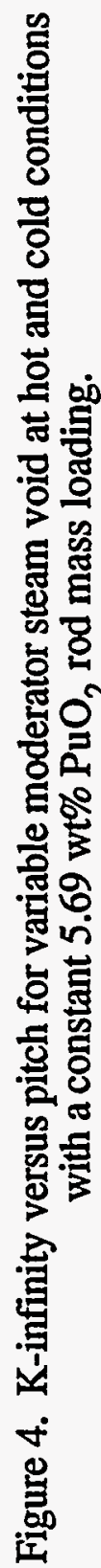




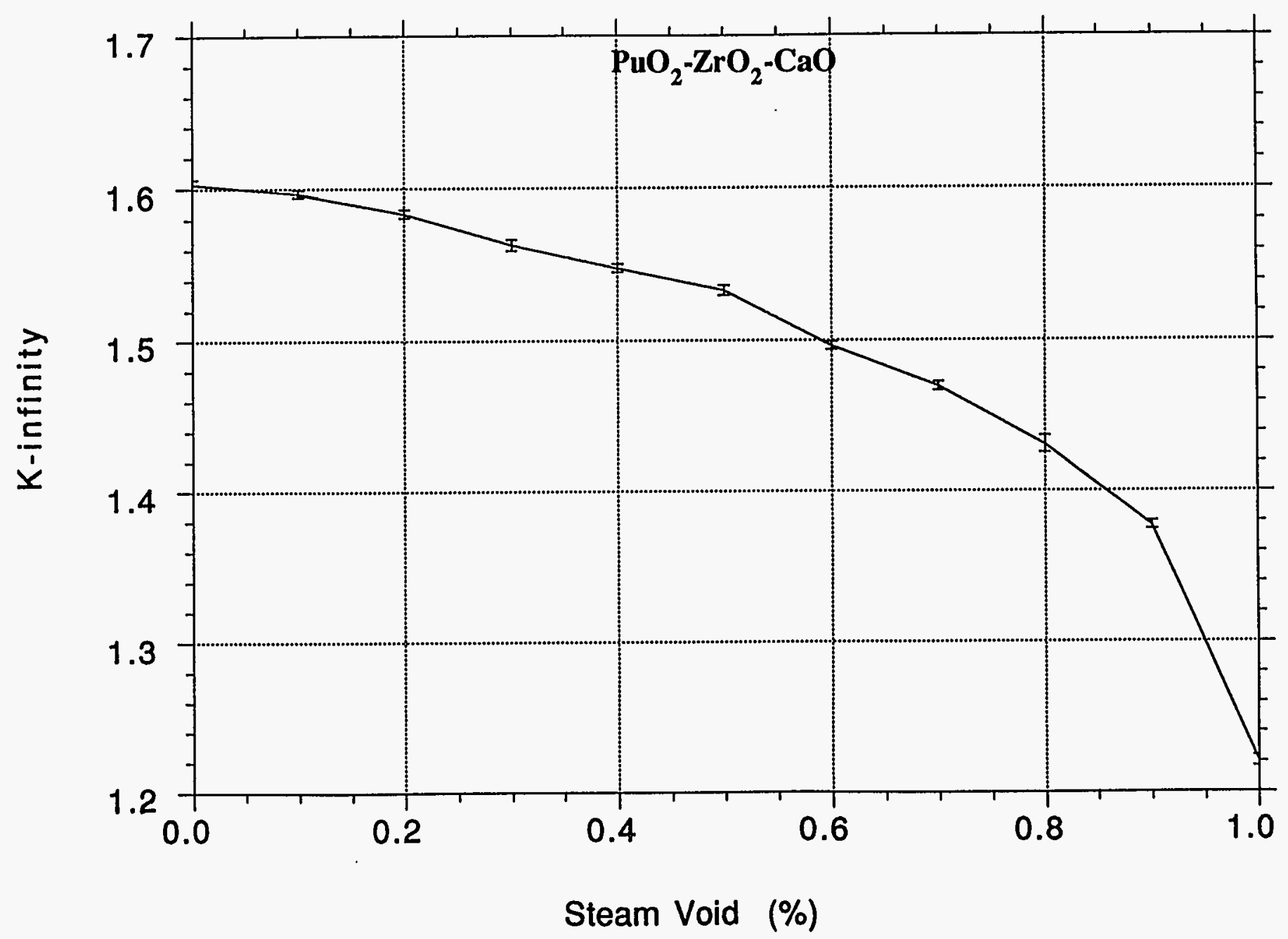

Figure 5. K-infinity as a function of moderator steam void percentage for the ABWR lattice, hot operational conditions, and a $5.69 \mathrm{wt} \% \mathrm{PuO}_{2}$ fuel rod mass loading. 


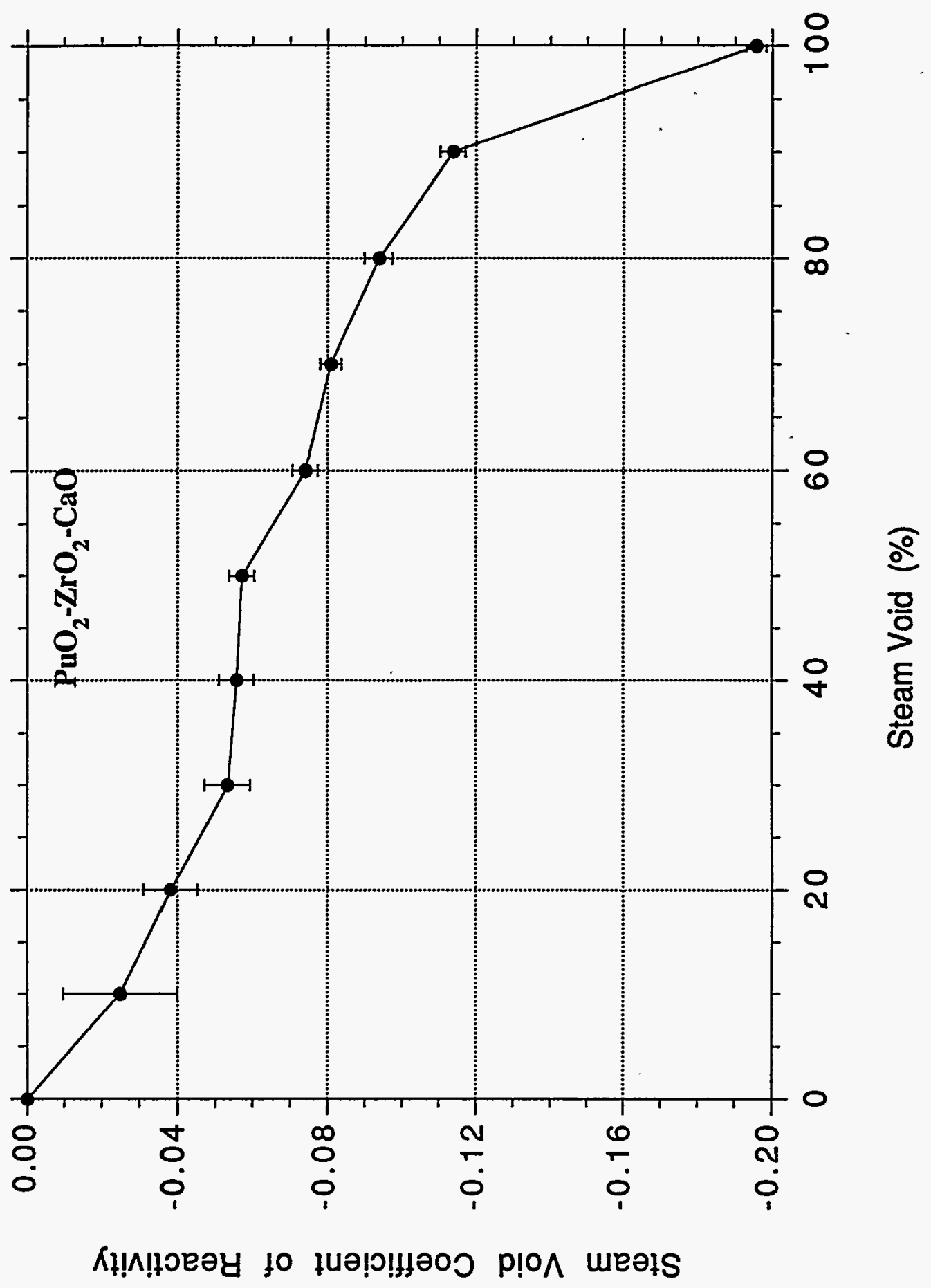

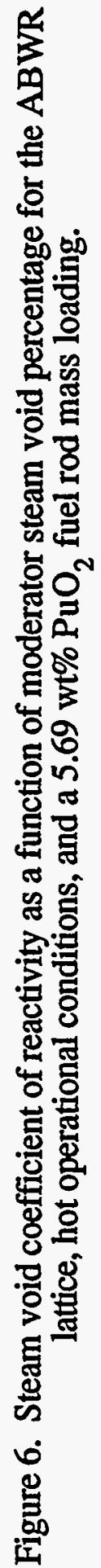




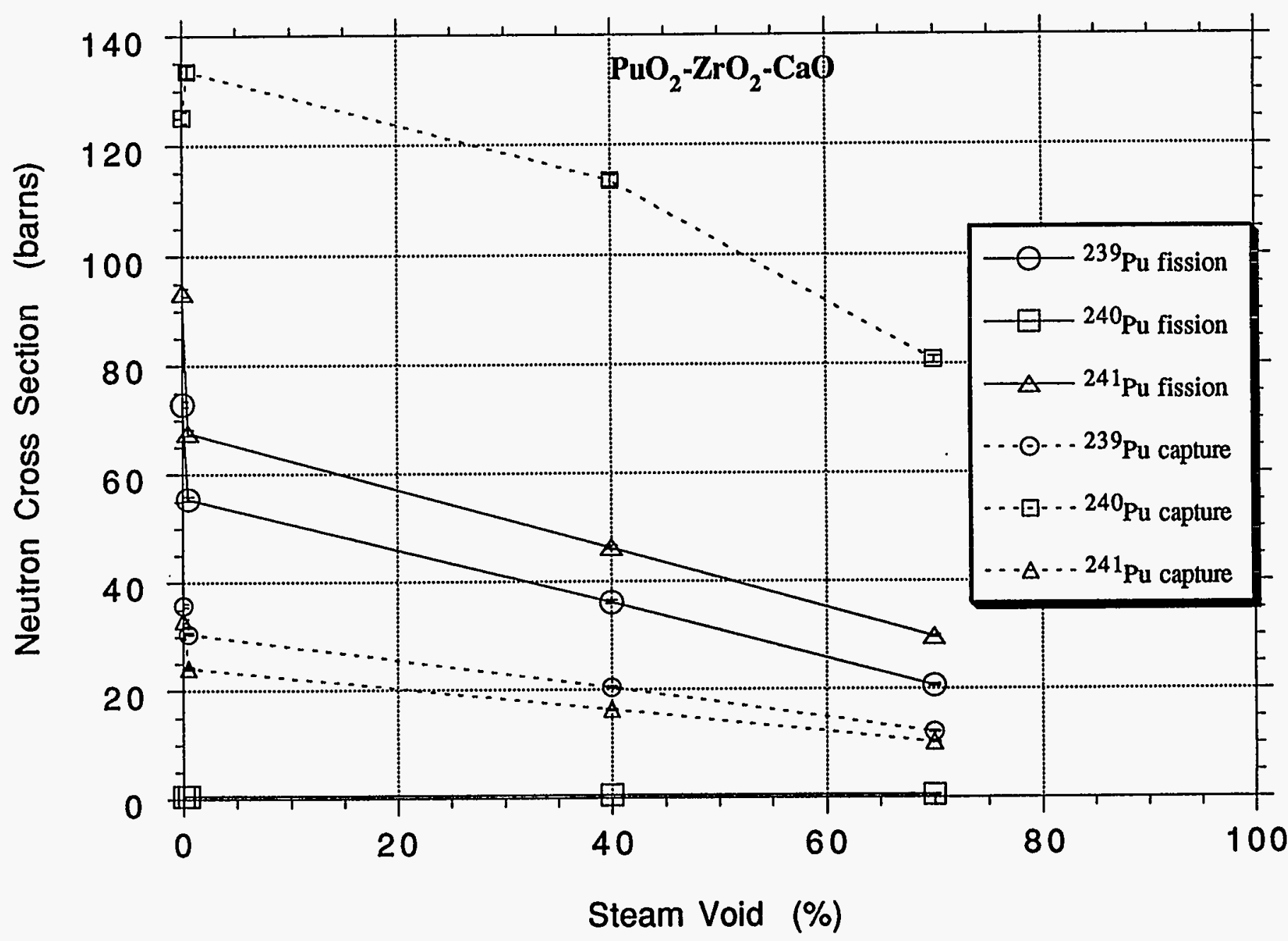

Figure 7. Plutonium isotope cross sections as a function of moderator steam void percentage for the $\mathrm{ABWR}$ lattice and a $5.69 \mathrm{wt} \% \mathrm{PuO}_{2}$ mass fuel rod loading. 


\subsection{Doppler Coefficient}

The COMBINE5-calculated prompt fuel temperature coefficients of reactivity (Doppler coefficients) are shown on Figure 8 as a function of fuel temperature and moderator steam void percent. The coefficients are negative over the fuel temperature range of $900-2400 \mathrm{~K}$. The magnitude is relatively flat, ranging between -0.2 and $-0.6 \mathrm{pcm} / \mathrm{K}$. The coefficients are calculated using the $\mathrm{ABWR}$ pitch, a $5.69 \mathrm{wt} \% \mathrm{PuO}_{2}$ mass loading, and hot operating conditions.

The Doppler coefficients for the $\mathrm{PuO}_{2}-\mathrm{ZrO}_{2}-\mathrm{CaO}$ fuel are negative as desired, but are approximately an order of magnitude less than those for commercial $\mathrm{UO}_{2}$ fuel. The negative magnitude can however be increased with the addition of a burnable rare-earth poison per Section 7.9.

\subsection{Isothermal Temperature Coefficient}

See Section 7.10 for the results and discussion discussion of the isothermal temperature coefficient of reactivity for the $\mathrm{PuO}_{2}-\mathrm{ZrO}_{2}-\mathrm{CaO}$ fuel with and without the burnable poison erbium.

\subsection{Burnup Poison Additives}

In order to hold down excess reactivity and increase heavy metal rod mass loadings, it is desirable to add a burnable poison to the base ternary fuel mixture. The rare-earths elements and their isotopes were chosen as potential poison additives, because of their resonance absorption to enhance the negative magnitude of the fuel Doppler coefficients. Specific rare-earth elements were then singled out based on their burnout characteristics. The ideal poison characteristic for a "deep burn" application is a relatively rapid burnout over the cycle so as to continually add reactivity to the fuel and extend the burnup as long as possible. With little poison remaining at EOL, very little hold down reactivity remains and maximum fuel burnup can achieved. The following five rare-earth poisons were evaluated for this purpose:

$\begin{array}{ll}\mathrm{Gd} & \text { (Gadolinium) } \\ \mathrm{Er} & \text { (Erbium) } \\ \mathrm{Eu} & \text { (Europium) } \\ \mathrm{Sm} & \text { (Samarium) } \\ \mathrm{Hf} & \text { (Hafnium) }\end{array}$

Oxide compounds of the these rare-earth elements can readily be homogeneously added to our base ternary fuel composition $\left(\mathrm{PuO}_{2}-\mathrm{ZrO}_{2}-\mathrm{CaO}\right)$. The rare-earth poisons were added to the $\mathrm{PuO}_{2}$ $\mathrm{ZrO}_{2}-\mathrm{CaO}\left(8.41 \mathrm{wt} \% \mathrm{PuO}_{2}\right.$ ) fuel composition in concentrations such that the BOL lattice $\mathrm{k}_{\text {inf }}$ for the base ternary composition with no poison decreased from 1.6 to approximately 1.3 with the addition of the poison. MCNP-generated BOL one-group neutron cross sections were used in ORIGEN2 input for the burnup calculations. It should be noted that these burnup calculations did not update the cross sections during the burnup as is done in Section 7.5 for the $\mathrm{PuO}_{2}-\mathrm{ZrO}_{2}-\mathrm{CaO}$ $\mathrm{Er}_{2} \mathrm{O}_{3}$ fuel composition detailed burnup calculation.

Figure 9 shows the $k$-infinity curves as a function of burnup (EFPD) for the five rare-earth poison fuel compositions and for comparison our base $\mathrm{PuO}_{2}-\mathrm{ZrO}_{2}-\mathrm{CaO}$ fuel composition without a burnable poison. The two poisons that allow the fuel rod to remain critical the longest and therefore would maximize plutonium burnup, were gadolinium and erbium with maximum burnups of at 970 and $930 \mathrm{EFPD}$, respectively for a $6.0 \mathrm{~kW} / \mathrm{ft}$ LHGR..

Using the longest achievable burnup as our sole criteria would lead to the selection of gadolinia as our burnable poison. However, we choose erbia over gadolinia for the following reasons: (1) the erbia burnup reactivity was nearly as good as gadolinia, (2) more erbia mass is actually added to the 


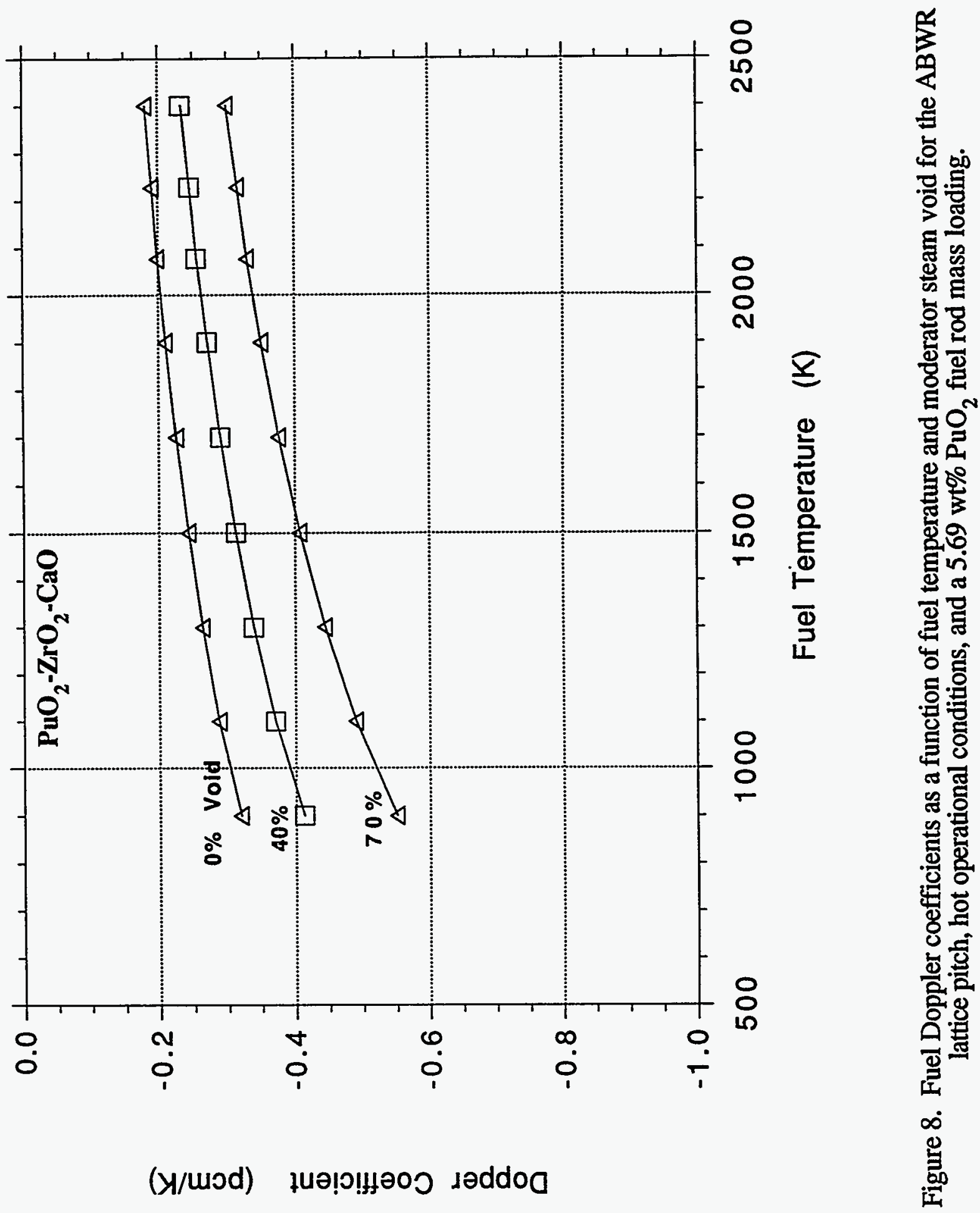




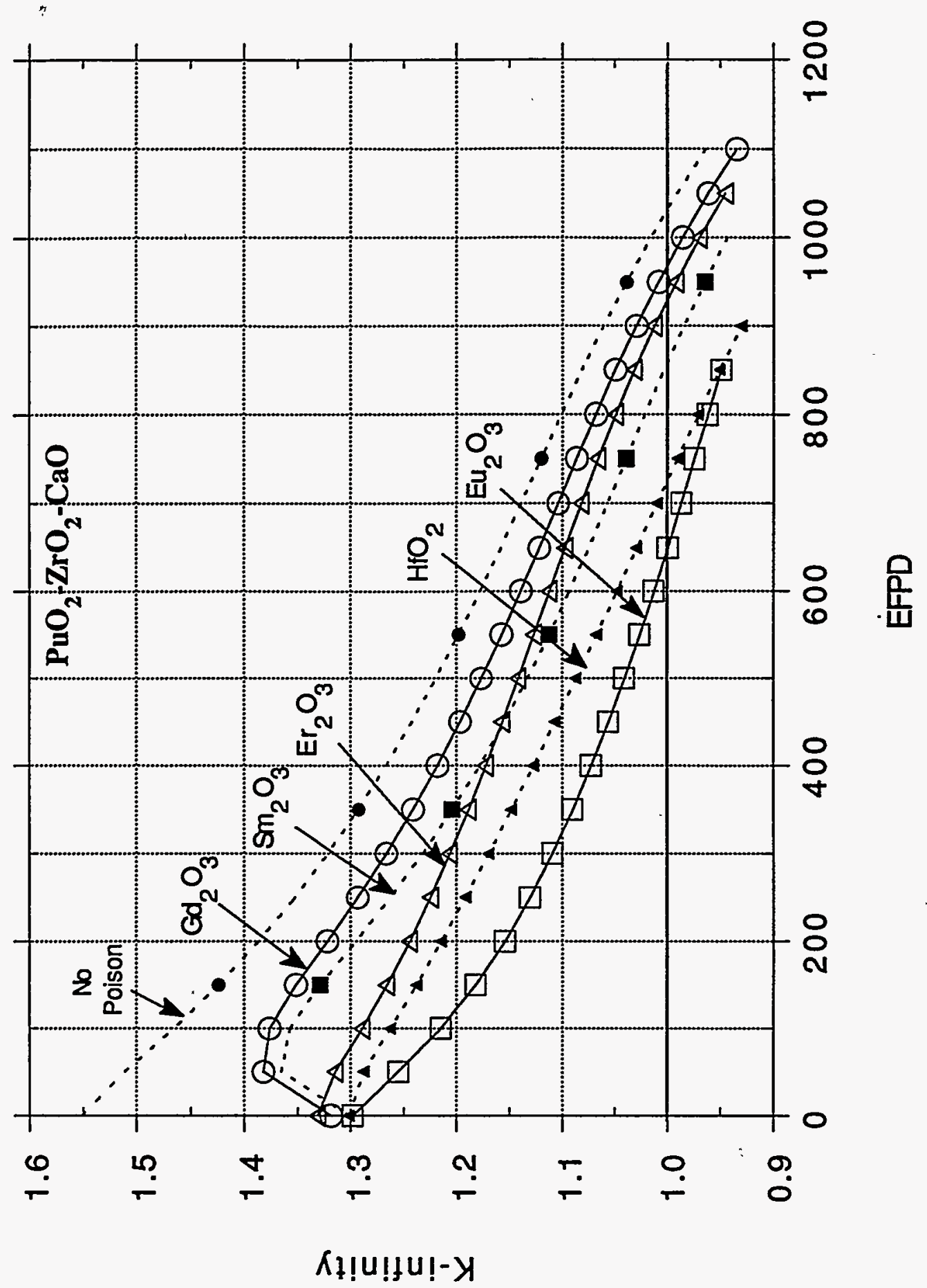

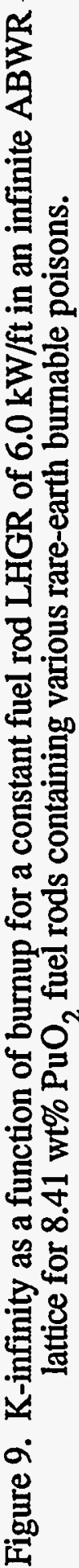


fuel composition for ease of homogenization, and (3) pellet radial power distributions would be more uniform with erbia. The erbia mass required to hold down the same amount of excess reactivity is much greater than the gadolinia mass, i.e. 28.2 grams/rod versus only 3.4 grams/rod. The larger erbia mass per rod improves the Doppler coefficient more than the gadolinia (Reference 2) and the small linear gadolinia rod mass loading $(0.12 \mathrm{~g} / \mathrm{cm})$ may cause concern over the uniformity of gadolinia distribution in the fuel pellets. In addition, from Reference 2, the use of erbia in a PWR produces a more negative isothermal temperature coefficient that may be of concern in the lower unvoided region of the BWR core.

Despite these considerations, gadolinia may still be an acceptable non-fertile fuel burnable poison in a BWR simply because of the potential for greater percent plutonium destruction and reduce total cost on a per mass basis. Further work would be required to design and neutronically verify gadolinia usage. 


\section{Z.0 NEUTRONIC EVALUATION-- $\mathrm{PuO}_{2}-\mathrm{ZrO}_{2}-\mathrm{CaO}_{-} \mathrm{Er}_{2} \mathrm{O}_{3} \mathrm{FUEL}$}

The following sections evaluate a plutonia-zirconia-calcia-erbia $\left(\mathrm{PuO}_{2}-\mathrm{ZrO}_{2}-\mathrm{CaO}-\mathrm{Er}_{2} \mathrm{O}_{3}\right)$ fuel composition in a Boiling Water Reactor environment using the ABWR fuel assembly dimensions and pitch for the infinite fuel lattice calculations. The effects on neutronic performance with the addition of the burnable poison, erbia, to the fuel composition can be compared with those of Section 6.0 for the base ternary fuel composition with no burnable poison.

\subsection{Lattice $\mathrm{k}$-infinity versus Erbia Concentration}

The infinite ABWR lattice k-infinity relationship to erbia and plutonia concentration is shown on Figure 10. These curves are useful in selecting the amount of erbia that is required to be added to hold down excess reactivity for a given plutonia loading. The lattice $k$-infinity decreases exponentially with increasing erbia volume percent of the fuel composition. Data are based on the ABWR pitch and a $40 \%$ moderator steam void.

One advantage of using a fast burning poison, such as erbia, is that the BOL poison concentration in the fuel composition can be increased or decreased within relatively broad limits and still achieve virtually the same plutonium destruction at EOL. Use of variable fuel poison concentrations in fuel pellets will allow the reactor designer flexibility in holding down life cycle excess reactivity for control system compatibility and radial and axial fuel loading variations in the fuel assembly for power flattening.

The neutronic evaluation that follows will focus on the non-fertile fuel composition with a single plutonia and erbia loading as specified in Table 4 below:

Table 4. Volume, atom, and weight percentages of the constituent materials in the $\mathrm{PuO}_{2}-\mathrm{ZrO}_{2}-$ $\mathrm{CaO}-\mathrm{Er}_{2} \mathrm{O}_{3}$ fuel composition.

\begin{tabular}{cccc} 
Constituent & $\mathrm{Vol} \%$ & $\mathrm{At} \%$ & $\mathrm{~W}+\%$ \\
\hline $\mathrm{PuO}_{2}$ & 4.0 & 3.80 & 8.3 \\
$\mathrm{ZrO}_{2}$ & 79.0 & 81.08 & 80.4 \\
$\mathrm{CaO}$ & 16.0 & 14.27 & 9.7 \\
$\mathrm{Er}_{2} \mathrm{O}_{3}$ & 1.0 & 0.85 & 1.6 \\
\hline
\end{tabular}

Selection of this fuel composition is based on previous calculational results and the arbitrary selection of a BOL lattice k-infinity of approximately 1.33. Adjustments of these constituents are of course possible and ultimately will be required to optimize a fuel assembly and account for both control rod and radial and axial fuel rod mass loadings necessary in a BWR. For the purposes of this study, the chosen values represent a good first order fuel composition constituent concentration estimate for typical BWR LHGRs and fuel burnup lifetimes and in addition provide a median point from which material property and performance sensitivity studies can be performed on the companion non-fertile LDRD study ${ }^{1}$.

\subsection{Yttria}

Substitution of the crystal stabilizing agent calcia for another stabilizing agent, namely, yttria has been proposed in the companion LDRD study ${ }^{1}$. The potential benefit of this substitution is a further improvement in the non-fertile fuel burnup performance. 


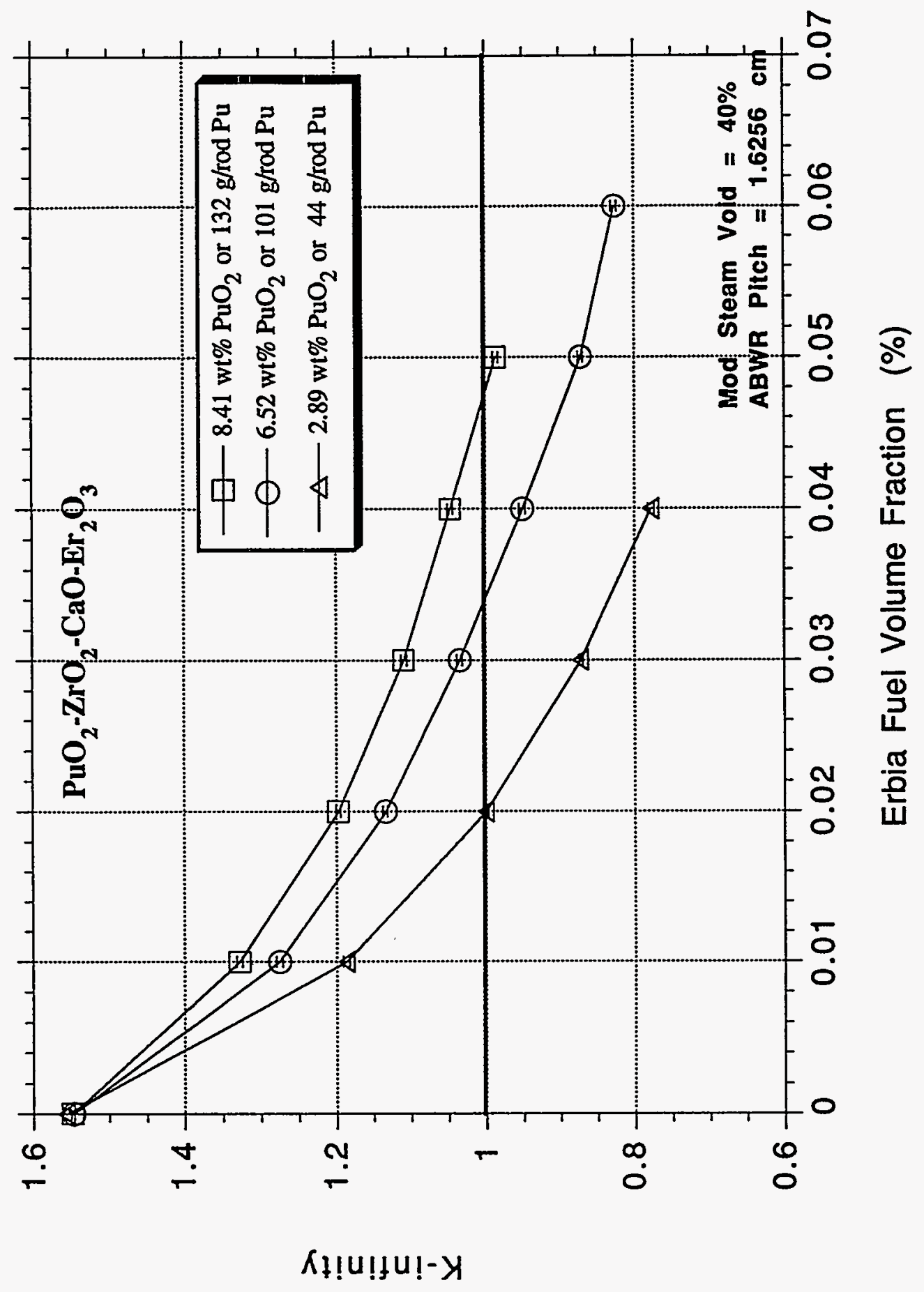

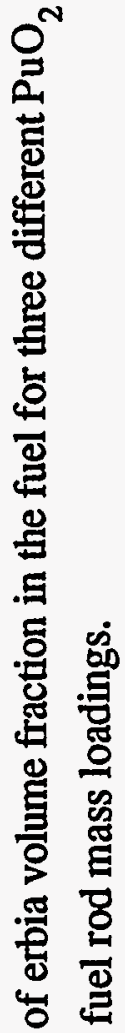

号

웅 
From a neutronic standpoint, the substitution of yttria for calcia should be of little consequence since both materials are relatively inert. However, just to make sure, MCNP input models were modified and executed with the yttrium cross sections substituted for the calcium cross sections in our $\mathrm{PuO}_{2}-\mathrm{ZrO}_{2}-\mathrm{CaO}$ fuel composition, which then became essentially a $\mathrm{PuO}_{2}-\mathrm{ZrO}_{2}-\mathrm{Y}_{2} \mathrm{O}_{3}$ fuel (both cases have a $5.69 \mathrm{wt} \% \mathrm{PuO}_{2}$ rod loading). The lattice k-infinity results are shown on Figure 11 as a function of $\mathrm{Er}_{2} \mathrm{O}_{3}$ volume percent added to the fuel composition. Minor variation is detected in the k-infinity values. It can be concluded that the substitution of yttria for the calcia will have very little effect on future neutronic analyses.

\subsection{Critically of a Single Fuel Assembly in Air}

Since a 10-kg sphere of solid plutonium metal (high density alpha phase) is critical ${ }^{29}$, a natural concern is the mass of plutonium metal contained in a weapons-grade plutonium non-fertile fuel BWR fuel assembly. For the selected non-fertile fuel composition (Section 7.1), a 64-rod assembly would contain at BOL approximately $8.45 \mathrm{~kg}$ Pu metal. This is below the $10-\mathrm{kg}$ limit, and the assembly which is a relatively high leakage configuration compared to the sphere is therefore expected to be subcritical.

The state of criticality of a single 64-rod fuel assembly with the non-fertile fuel was calculated in air using MCNP. The k-effective value calculated was $0.02048 \pm 0.00004$, indicative of a very subcritical configuration. However, handling concerns may still arise from array stacking, flooding, radiation emission, and of course proliferation and diversion.

\subsection{ABWR Pitch}

As in Section 6.1, the under- or overmoderated question of the ABWR assembly pitch is again addressed for the non-fertile $\mathrm{PuO}_{2}-\mathrm{ZrO}_{2}-\mathrm{CaO}-\mathrm{Er}_{2} \mathrm{O}_{3}$ fuel composition. Figure 12 shows the hot lattice k-infinity as a function of lattice pitch (ABWR pitch indicated on the figure). The lattice $k$ infinity is calculated at $\mathrm{BOL}$ for the three moderator steam void conditions $(0,40$, and $70 \%)$ at hot operational conditions and at cold conditions with zero moderator steam void.

It is clear from Figure 12 that the $\mathrm{ABWR}$ lattice pitch with our $\mathrm{BOL} \mathrm{PuO}_{2}-\mathrm{ZrO}_{2}-\mathrm{CaO}-\mathrm{Er}_{2} \mathrm{O}_{3}$ fuel composition remains in the as desired undermoderated condition for each of the four conditions evaluated. These results confirm those obtained in Section 6.1 for the $\mathrm{PuO}_{2}-\mathrm{ZrO}_{2}-\mathrm{CaO}$ fuel composition. The ABWR pitch is further validated as a function of burnup with the calculation of steam void coefficients of reactivity in Section 7.8 .

\subsection{Burnup Calculations}

Burnup calculations were performed in accordance with the methodology described in Section 3.0. The MCNP-calculated k-infinity values as a function of EFPD are shown on Figure 13 for both the 6.0 and 12.0 LHGRs and the 0,40 , and $70 \%$ moderator steam void conditions.

The reactivity letdown (Figure 13) is relatively flat for the $6.0 \mathrm{~kW} / \mathrm{ft}$ LHGR and as expected has a sharper drop off for the $12.0 \mathrm{~kW} / \mathrm{ft}$ LHGR. The product of LHGR and the maximum achievable EFPD appears to be nearly constant for each of the three different moderator steam void conditions. One point of interest is the effect of the moderator steam void on the burnup duration, i.e. the greater the steam void, the sooner the lattice goes subcritical, and less EFPD are achieved that ultimately results in a lower plutonium destruction at EOL. 

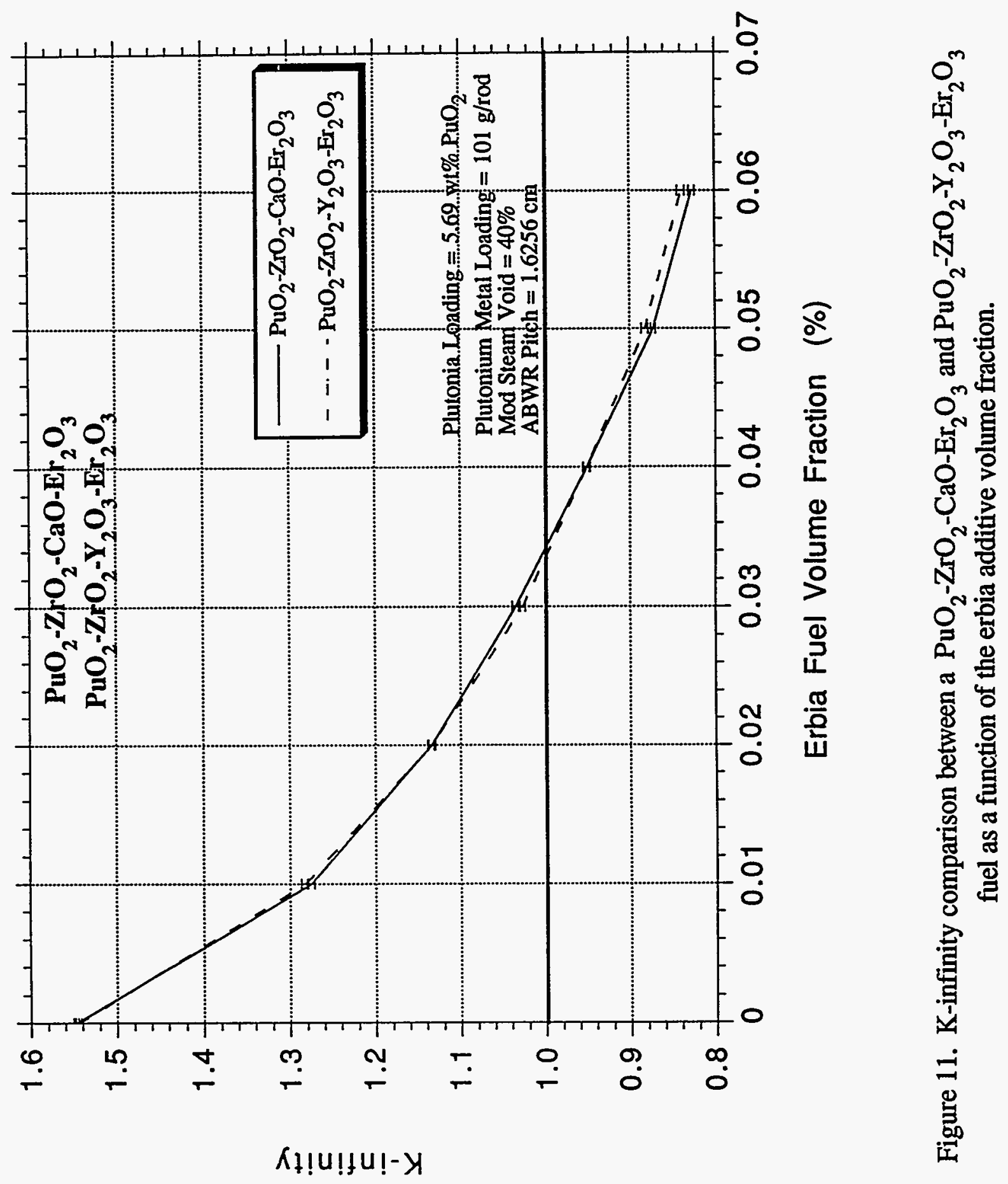


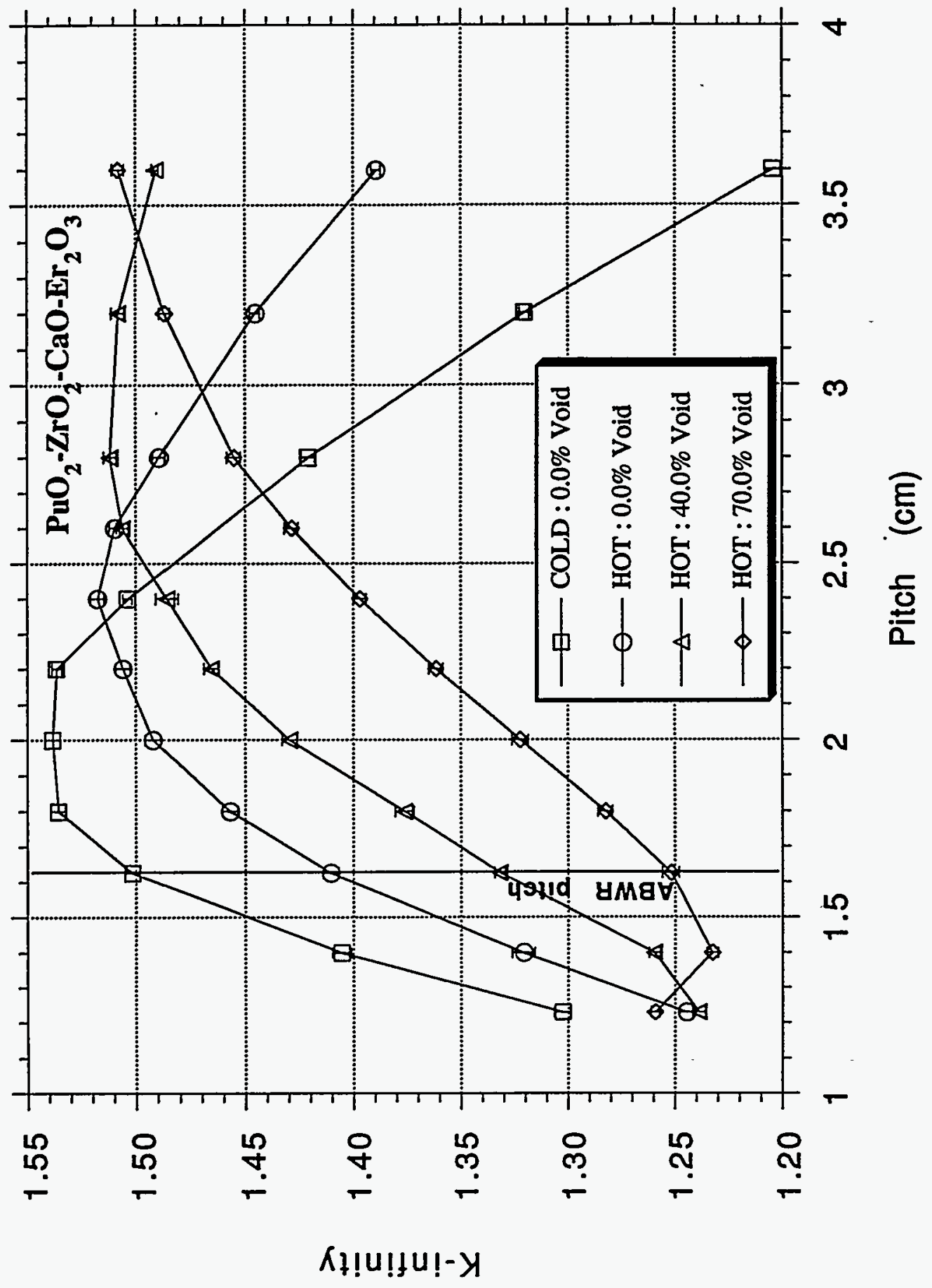

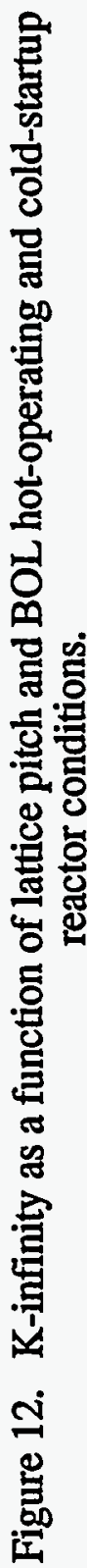




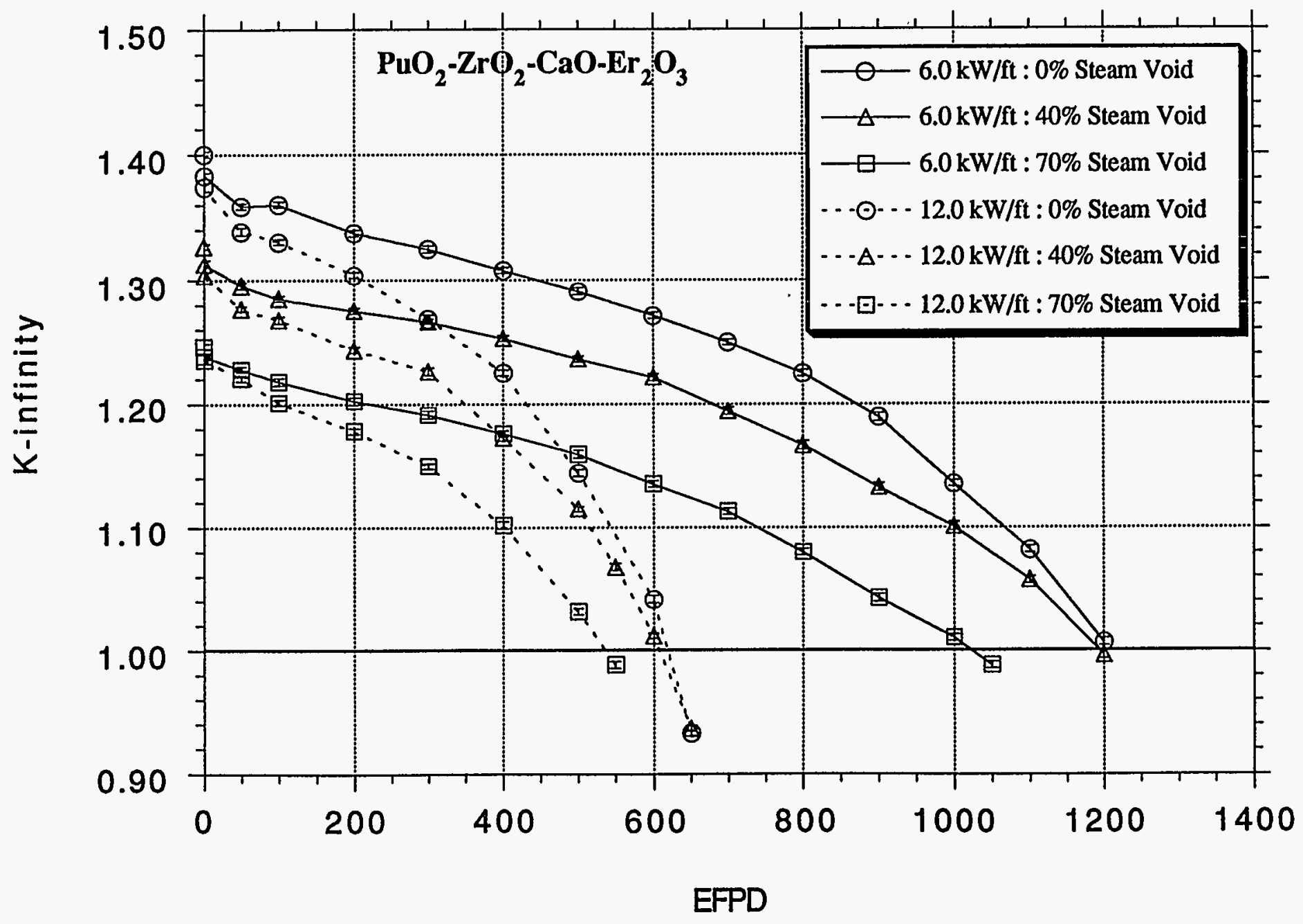

Figure 13. K-infinity as a function of burnup, linear heat generation rate, and moderator steam void for steady-state hot operating conditions using the ABWR lattice pitch. 


\subsection{Plutonium Destruction}

Plutonium destruction is estimated for an infinite BWR lattice at hot operating conditions based on the number of EFPD at which the fuel lattice remains critical ( $\left.\mathrm{k}_{\mathrm{inf}} \geq 1.0\right)$. The percent plutonium destruction is defined as a ratio of the plutonium mass fissioned to the initial BOL plutonium mass loading. Plutonium destruction is given for the combined plutonium isotopes and separately for the. ${ }^{239} \mathrm{Pu}$ isotope and is given as a function of moderator steam void percent $(0,40$, and $70 \%)$ and linear heat generation rate $(6.0$ and $12.0 \mathrm{~kW} / \mathrm{ft})$. The results are given in Table 5 . Individual gram masses for each of the plutonium isotopes are also provided for BOL and EOL. It should be noted that the greater the moderator steam void condition, the lower the percent plutonium destruction, for example, $71-73 \%$ plutonium destruction for the 0 to $40 \%$ steam void condition versus $60 \%$ for the $70 \%$ steam void condition.

Figure 14 shows the gram masses per fuel rod of the plutonium isotopes ${ }^{239} \mathrm{Pu},{ }^{240} \mathrm{Pu},{ }^{241} \mathrm{Pu}$, and ${ }_{242} \mathrm{Pu}$ ) as a function of burnup (EFPD). This particular case is for the $6.0 \mathrm{~kW} / \mathrm{ft}$ LHGR and the $40 \%$ moderator steam void condition. Figure 15 shows the gram masses per fuel rod for the erbium isotopes (166Er, ${ }^{167} \mathrm{Er}$, and ${ }^{168} \mathrm{Er}$ ) as a function of burnup for the same LHGR and steam void condition. Very little of the ${ }^{167} \mathrm{Er}$ isotope (largest thermal absorption cross section of the erbium isotopes) remains at EOL.

In a BWR, the steam void in the moderator increases with core height. Therefore, one might expect lower plutonium destruction percentages at the higher core elevations and higher destruction percentages at the higher density moderator in the lower and middle core elevations. Although the percent plutonium destruction values in Table 5 represent a "maximum" destruction level under the conditions of the analysis here, these levels are believed to be achievable with an effective fuel and core power management scheme. Higher percent destructions may be possible if a reduction in steam quality could be tolerated.

\subsection{Production of Higher-order Actinides}

Table 5 also gives the gram quantities for the significant higher-order actinides per fuel rod that are produced during exposure. The mass quantities include contributions from four isotopes: ${ }^{241} \mathrm{Am}$, ${ }^{243} \mathrm{Am},{ }^{242} \mathrm{Cm}$, and ${ }^{244} \mathrm{Cm}$. Inclusion of two other actinides, ${ }^{245} \mathrm{Cm}$ and ${ }^{246} \mathrm{Cm}$, would increase the total mass values by approximately $5-10 \%$. All other higher-order actinide concentrations were relatively insignificant. The 2-3 gram quantities of actinides per fuel rod at EOL represent about $10 \%$ of the total EOL actinide mass including the plutonium isotopes.

\subsection{Moderator Steam Void Coefficient of Reactivity}

The moderator steam void coefficient of reactivity as defined in Section 6.2 is calculated at four points over the fuel burnup lifetime $(0,600,1000,1200 \mathrm{EFPD})$ for the $6.0 \mathrm{~kW} / \mathrm{ft}$ LHGR case. Zero EFPD corresponds to a BOL fuel composition, 600 EFPD corresponds to a MOL fuel composition, and 1000 and 1200 EFPD span the EOL fuel compositions for the 0-70\% steam void (Figure 13). At each time point the fuel composition is characterized by the appropriate concentrations of the 5 plutonium isotopes, 4 higher-order actinides, 2 burnable poison (erbia) isotopes, and 58 fission products as predicted by the ORIGEN2 code.

Figure 16 shows the hot ABWR lattice k-infinity as a function of moderator steam void percentage at each of the four burnup points. The k-infinity values drop off with increasing steam void that results in negative steam void coefficients of reactivity for all points over the fuel burnup lifetime. Figure 17 shows the dimensionless negative moderator steam void coefficients of reactivity as a function of steam void for the four points in the burnup. 
Table 5. Isotopic and total plutonium rod masses at BOL and EOL along with the maximum percent plutonium destruction and destruction rate for the given EFPDs after which the fuel assembly goes subcritical.

\begin{tabular}{|c|c|c|c|c|c|c|c|c|c|c|c|c|}
\hline $\begin{array}{l}\text { Burnup } \\
\text { (EFPDs) }\end{array}$ & $\begin{array}{c}\text { UHGR } \\
(k W / f t)\end{array}$ & $\begin{array}{l}\text { Steam } \\
\text { Void } \\
(\%)\end{array}$ & $\begin{array}{c}\text { Pu-238 } \\
\text { (gm/rod) }\end{array}$ & $\begin{array}{c}\text { Pu-239 } \\
\text { (gm/rod) }\end{array}$ & $\begin{array}{c}\text { Pu240 } \\
\text { (gm/rod) }\end{array}$ & $\begin{array}{c}\mathrm{Pu}-241 \\
\text { (gm/rod) }\end{array}$ & $\begin{array}{c}\mathrm{Pu}-242 \\
\text { (gm/rod) }\end{array}$ & $\begin{array}{l}\text { Total Pu } \\
\text { (gm/rod) }\end{array}$ & $\begin{array}{c}\text { Total Pu } \\
\text { Destruct } \\
(\%) \\
\end{array}$ & $\begin{array}{c}\text { Pu-239 } \\
\text { Destruct } \\
(\%) \\
\end{array}$ & \begin{tabular}{|c|} 
Total Pu" \\
Destruct Rate \\
(g/rod/yr) \\
\end{tabular} & $\begin{array}{l}\text { Actinide** } \\
\text { Product } \\
\text { (gm/rod) }\end{array}$ \\
\hline 0.0 (BOL) & & & 0.02 & 123.78 & 7.67 & 0.46 & 0.03 & 131.95 & 0.0 & 0.0 & 0.0 & 0.0 \\
\hline 1209 & 6 & 0 & 0.37 & 8.22 & 15.56 & 8.98 & 4.90 & 38.03 & 71.2 & 93.4 & 28.4 & 2.4 \\
\hline 1200 & 6 & 40 & 0.44 & 10.04 & 12.69 & 10.35 & 4.56 & 38.06 & 71.2 & 91.9 & 28.6 & 3.0 \\
\hline 1025 & 6 & 70 & 0.37 & 22.73 & 12.97 & 12.66 & 2.94 & 51.66 & 60.8 & 81.6 & 28.6 & 2.7 \\
\hline 625 & 12 & 0 & 0.20 & 6.93 & 13.85 & 8.87 & 5.26 & 35.11 & 73.4 & 94.4 & 56.6 & 2.5 \\
\hline 610 & 12 & 40 & 0.22 & 9.71 & 11.69 & 10.41 & 4.72 & 36.76 & 72.1 & 92.2 & 57.0 & 2.9 \\
\hline 525 & 12 & 70 & 0.19 & 23.69 & 12.29 & 13.09 & 2.90 & 52.17 & 60.5 & 80.9 & 55.5 & 2.5 \\
\hline
\end{tabular}

* (g/rod/yr) is grams of plutonium per Effective Full Power Year or 365 EFPDs.

- Higher Order Actinides [Am-241, Am-243, Cm-242, Cm-244] 


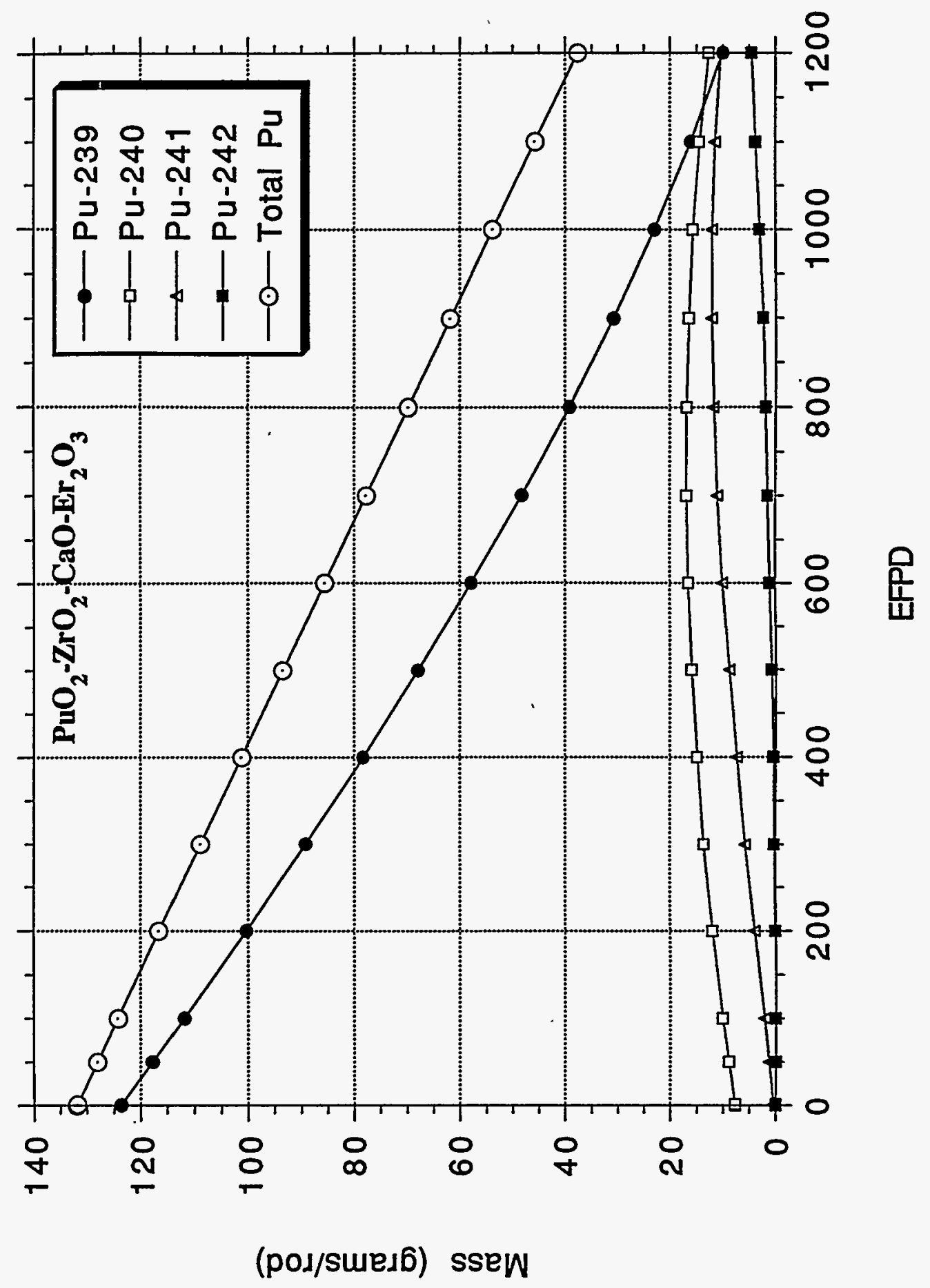

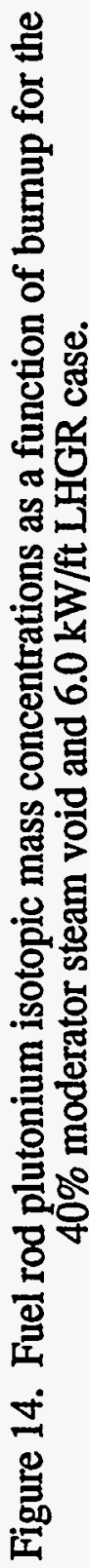




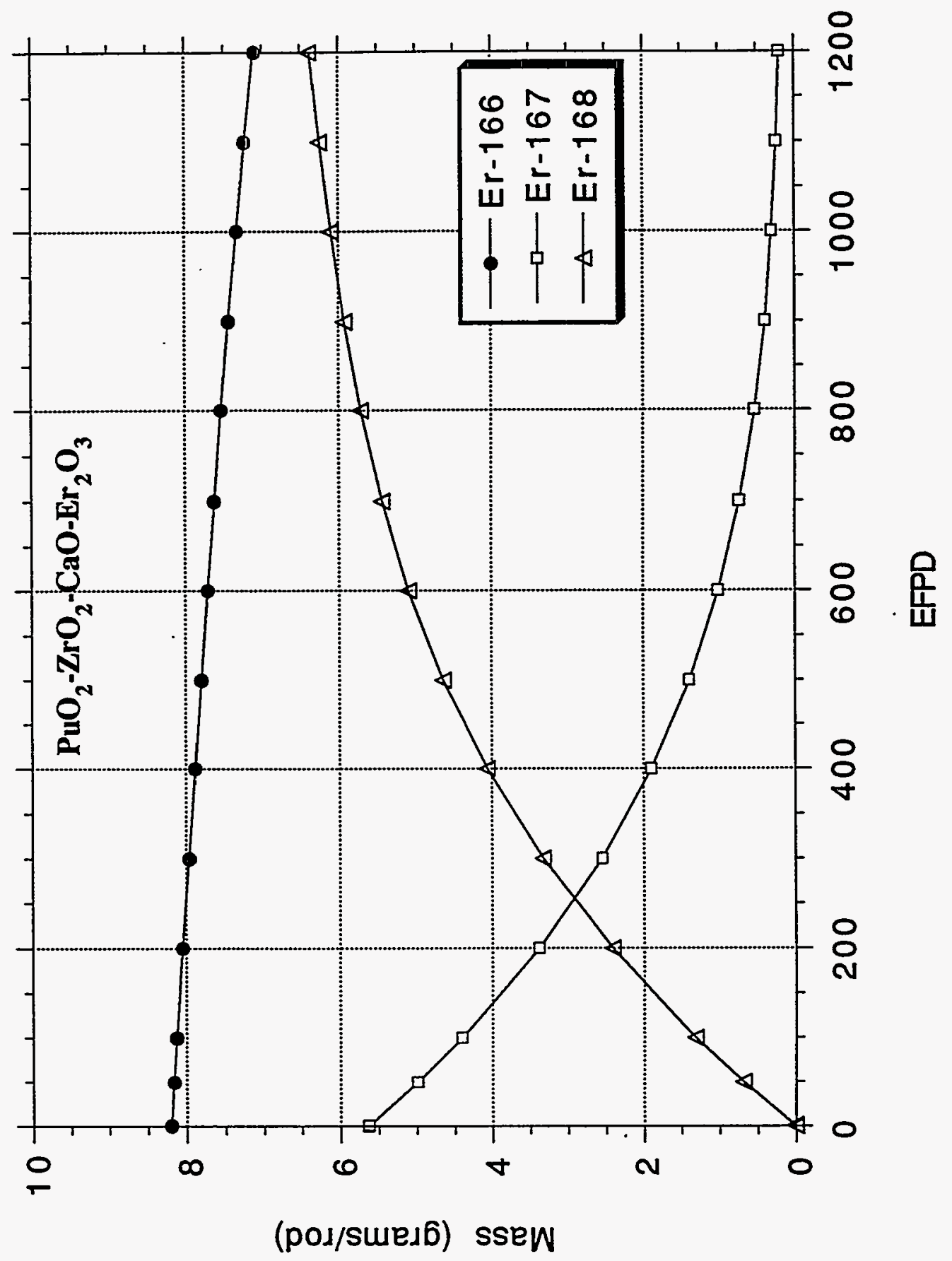

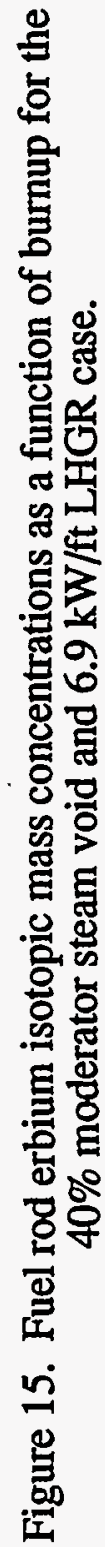




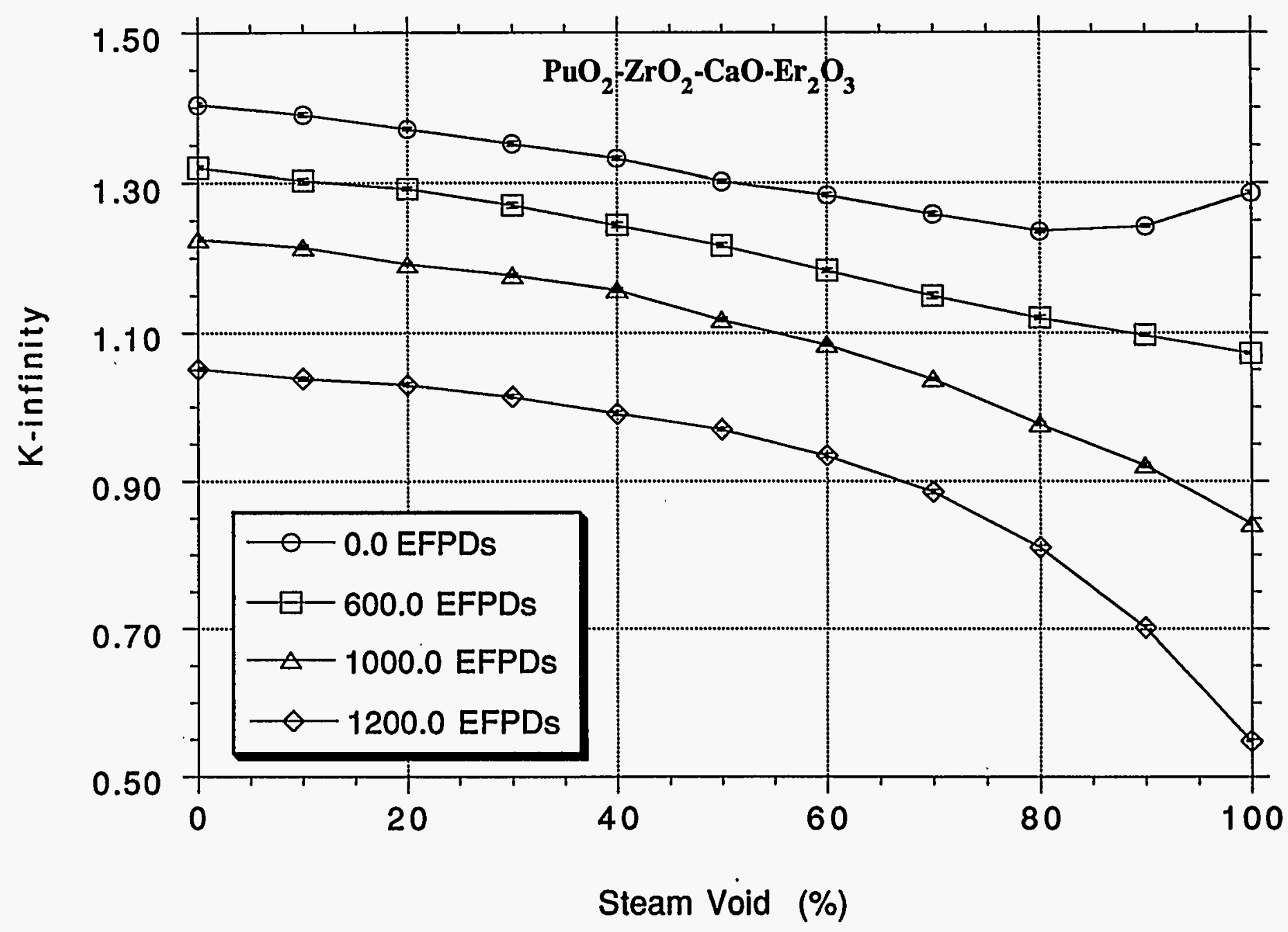

Figure 16. K-infinity as a function of moderator steam void and burnup for steady-state hot operating conditions and a $6.0 \mathrm{~kW} / \mathrm{ft}$ fuel rod LHGR. 


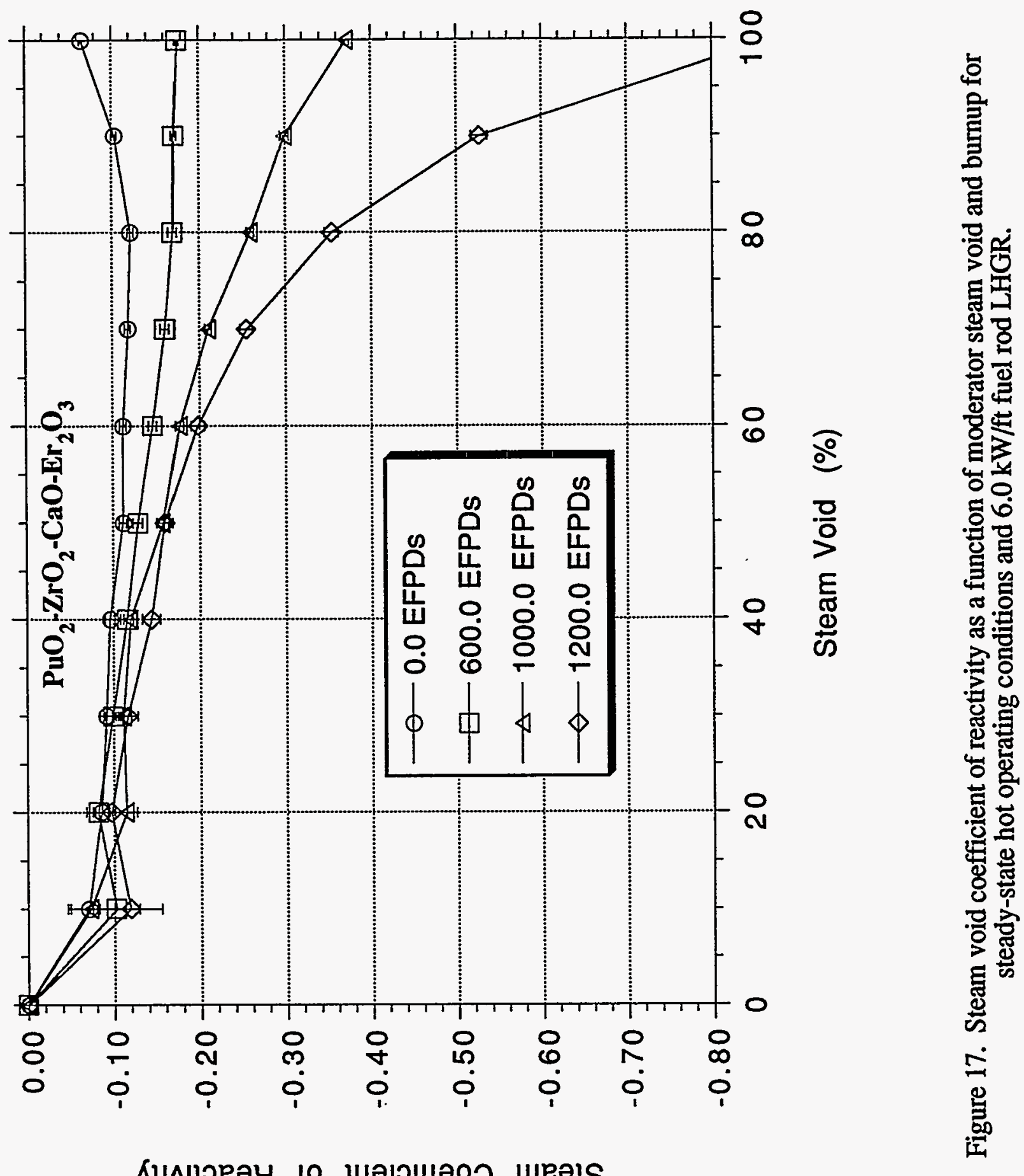


It may also desirable to ensure that the BWR design condition at room temperature also has negative void coefficients ${ }^{30}$. Figure 18 shows the cold ABWR lattice $k$-infinity as a function of moderator void percentage at three points in the burnup. The $k$-infinity values drop off with increasing void and again results in negative void coefficients of reactivity over the fuel burnup lifetime. Figure 19 shows the dimensionless negative moderator void coefficients of reactivity as a function of void for the three burnup points. The one positive value for the $1200 \mathrm{EFPD}$ at $10 \%$ void condition is believed to be an MCNP statistical aberration and would most likely be negative if more particles were run to improve the Monte Carlo statistical result.

\subsection{Doppler Coefficient}

The COMBINE6-calculated prompt fuel temperature coefficients of reactivity (Doppler coefficients) are shown on Figure 20 as a function of fuel temperature, moderator steam void percentage, and three burnup points. The moderator temperature is assumed to be held constant at approximately $600 \mathrm{~K}$. The Doppler coefficients calculated at the three burnup points correspond to BOL (0 EFPD), MOL (600 EFPD), and EOL (1200 EFPD) for the $6.0 \mathrm{~kW} / \mathrm{ft}$ LHGR case. The coefficients are calculated using the ABWR pitch under hot operating conditions.

The Doppler coefficients are all negative as desired over the fuel temperature range of $900-2200 \mathrm{~K}$. The coefficients attain a greater negative magnitude as the fuel temperature is decreased and the burnup increases. The latter conclusion is due primarily to a net increase of parasitic resonance absorption from buildup of $240 \mathrm{Pu}$ and fission products versus the loss of ${ }^{16} \mathrm{Er}$. The magnitude of the coefficients at 0 and 600 EFPD are relatively insensitive to moderator steam void, however, the sensitivity increases at higher burnups as is evident in the 1200 EFPD case. At 1200 EFPD, the coefficients range from approximately -0.8 to $-2.0 \mathrm{pcm} / \mathrm{K}$ over an $800-2200 \mathrm{~K}$ temperature range and become more negative in magnitude with increasing moderator steam void.

\subsection{Isothermal Temperature Coefficient}

The isothermal temperature coefficient of reactivity (ITC) was calculated over the temperature range of $300-500 \mathrm{~K}$. The lattice $\mathrm{k}$-infinity values at each temperature were calculated with the fuel, clad, and moderator at the same temperature. The temperature range should have extended up to approximately $550 \mathrm{~K}$, i.e. saturation conditions in the ABWR at $1050 \mathrm{psig}$, however, we were limited by the availability of $S(\alpha, \beta)$ neutron cross section evaluations for hydrogen in light water. Trends to higher temperatures however are easy to discern from the figures.

Figure 21 shows the variation in the isothermal temperature coefficients as a function of burnup. At BOL (0.0 EFPD at $6.0 \mathrm{~kW} / \mathrm{ft}$ ), the isothermal coefficient is negative over the entire temperature range. The same is true for the MOL ( $600 \mathrm{EFPD}$ at $6.0 \mathrm{~kW} / \mathrm{ft}$ ), but becomes less negative compared to the BOL values. As the burnup progresses, somewhere between 600 and 1200 EFPD the isothermal coefficients become positive, since at EOL (1200 EFPD at $6 \mathrm{~kW} / \mathrm{ft}$ ) the coefficients are positive.

Positive ITCs were also observed in the previous non-fertile fuel study ${ }^{2}$ for low mass loadings of PWR fuel rods and high reactivity. These rods contained no burnable poison to hold down reactivity. However, when a burnable poison (gadolinia, europia, or erbia) was added to these rods the plutonia content increased and the isothermal temperature coefficients became negative. The addition of the poison was at that time assumed to be the major player contributing to the negative coefficient.

However, Figure 22 clearly shows that a BWR fuel rod loaded with approximately $8.41 \mathrm{wt} \% \mathrm{PuO}_{2}$ and no burnable poison also has a negative ITC at BOL over the isothermal temperature range of interest. This fuel rod contains approximately ten times the plutonia compared to the lightly loaded 


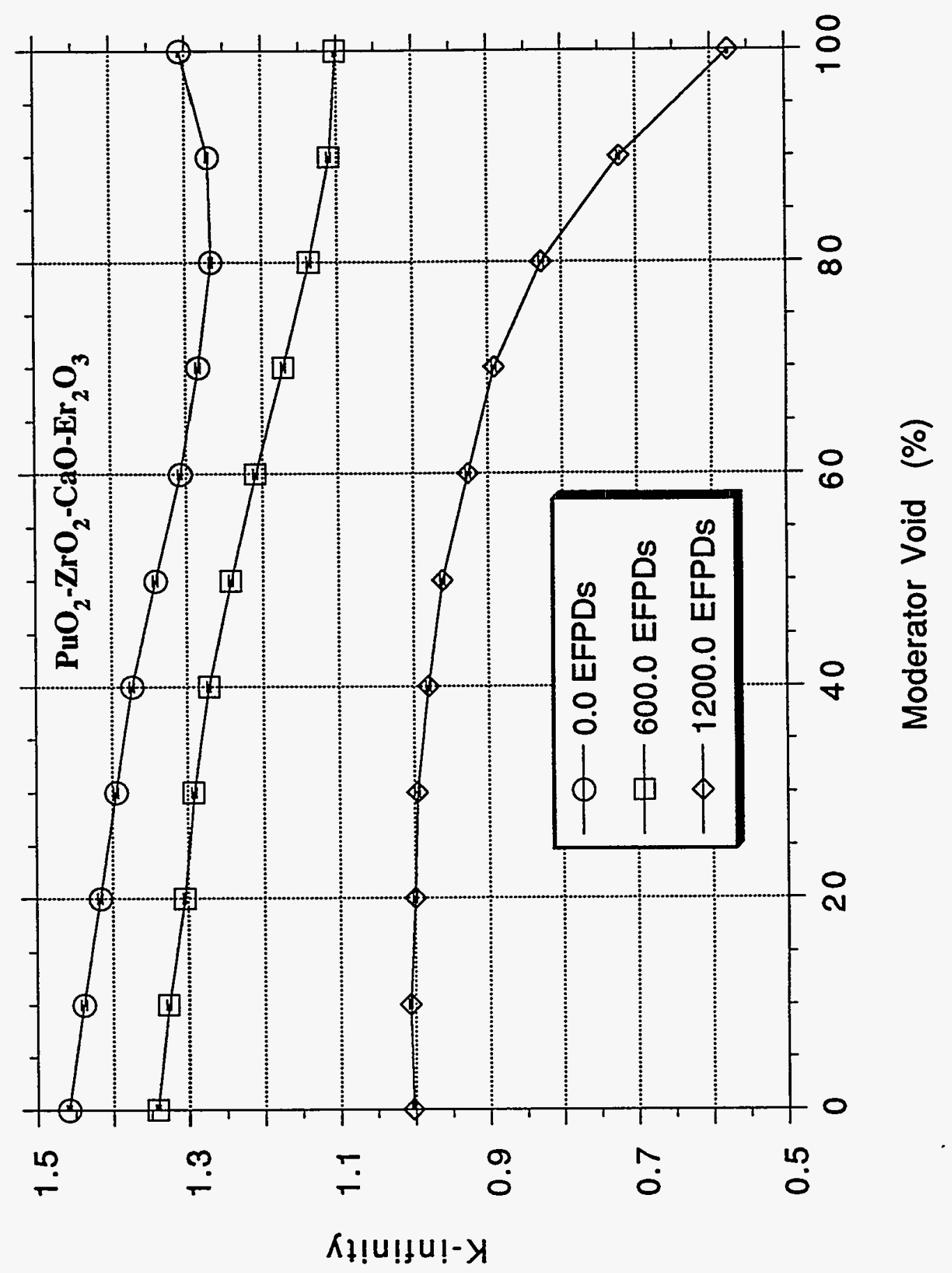

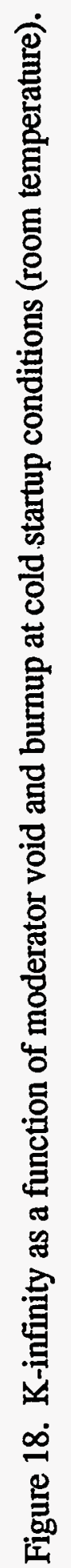




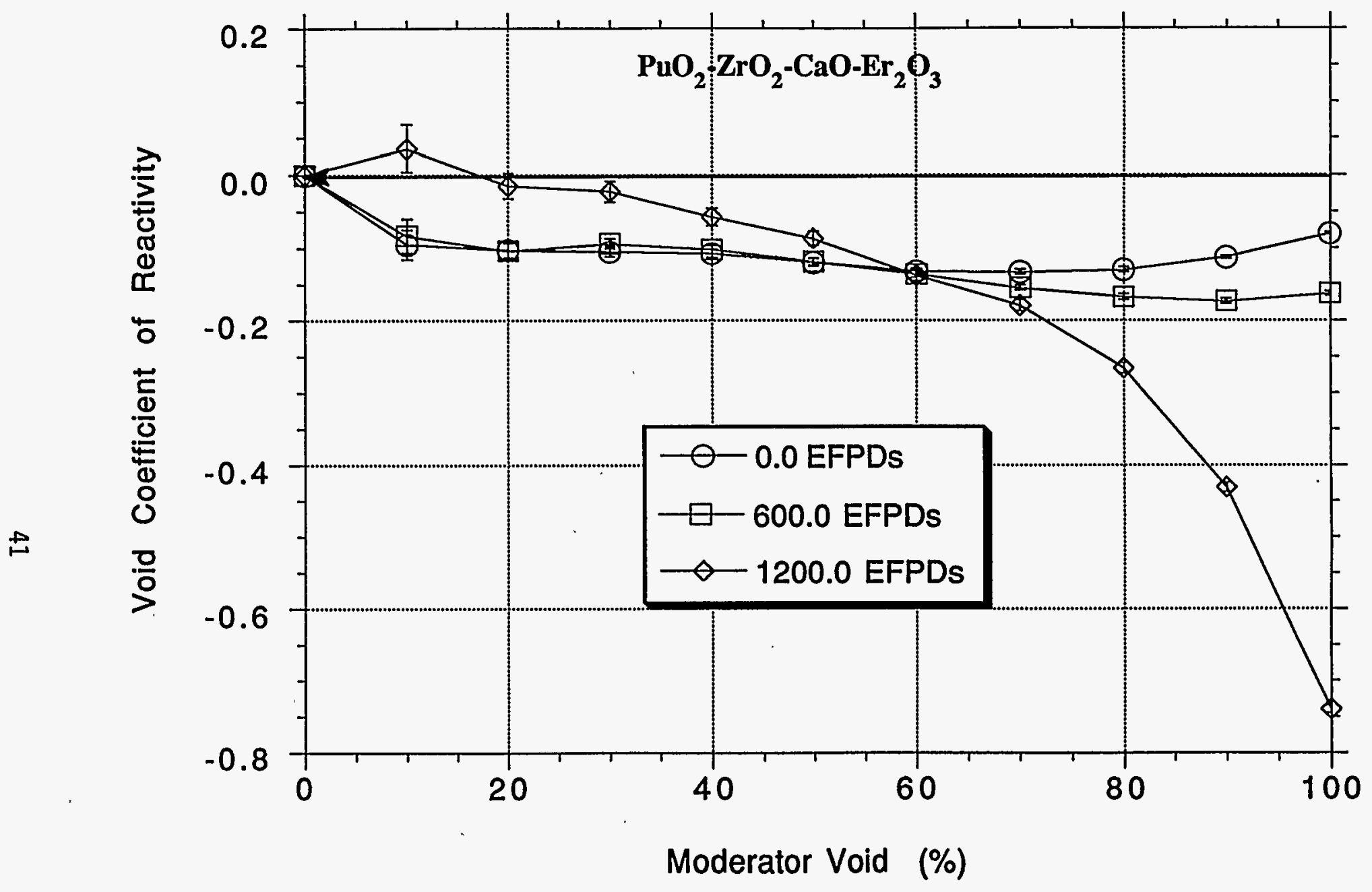

Figure 19. Void coefficient of reactivity as a function of void and burnup for cold startup conditions (room temperature). 


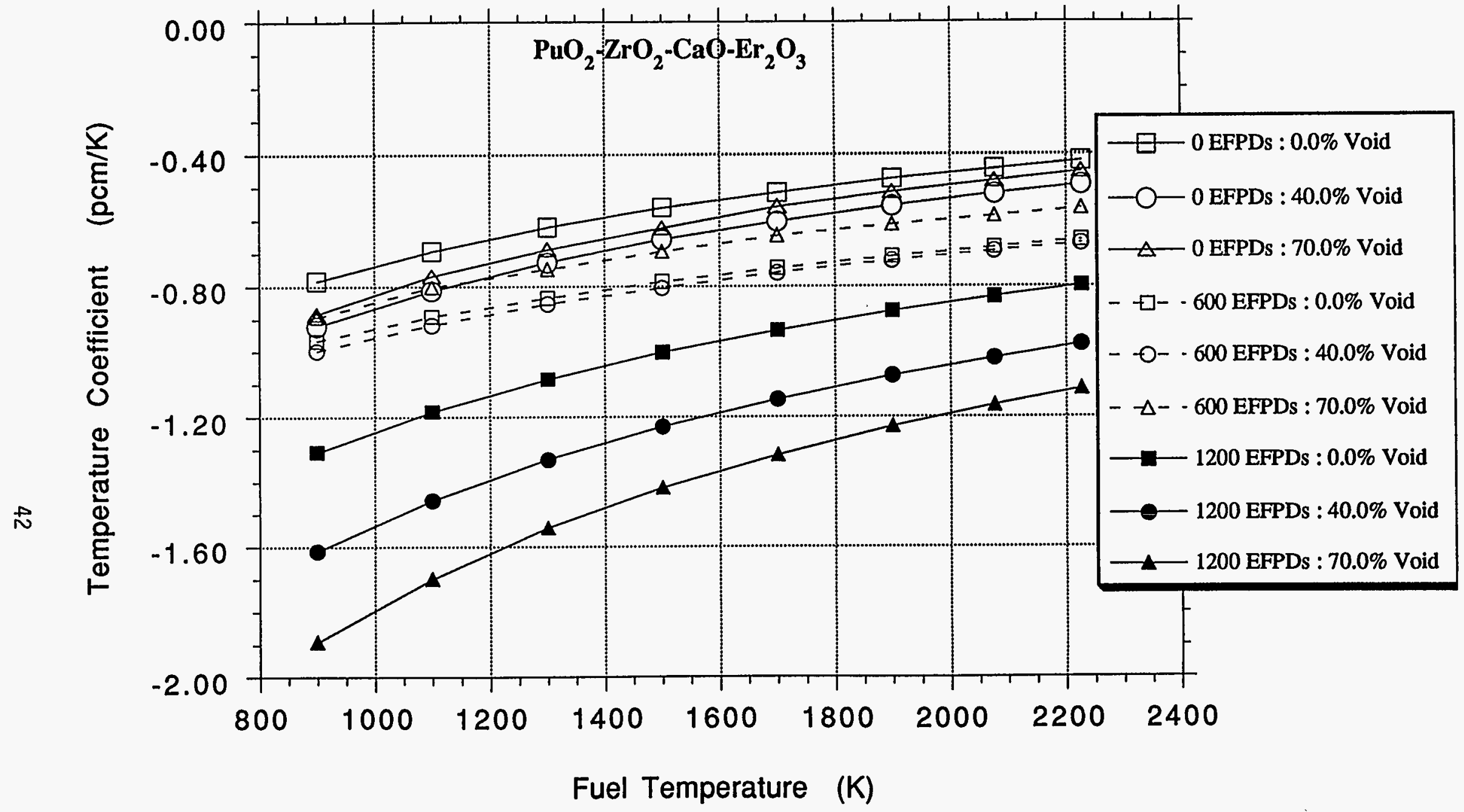

Figure 20. Doppler temperature coefficients of reactivity as a function of moderator steam void and fuel burnup at hot operating conditions. 


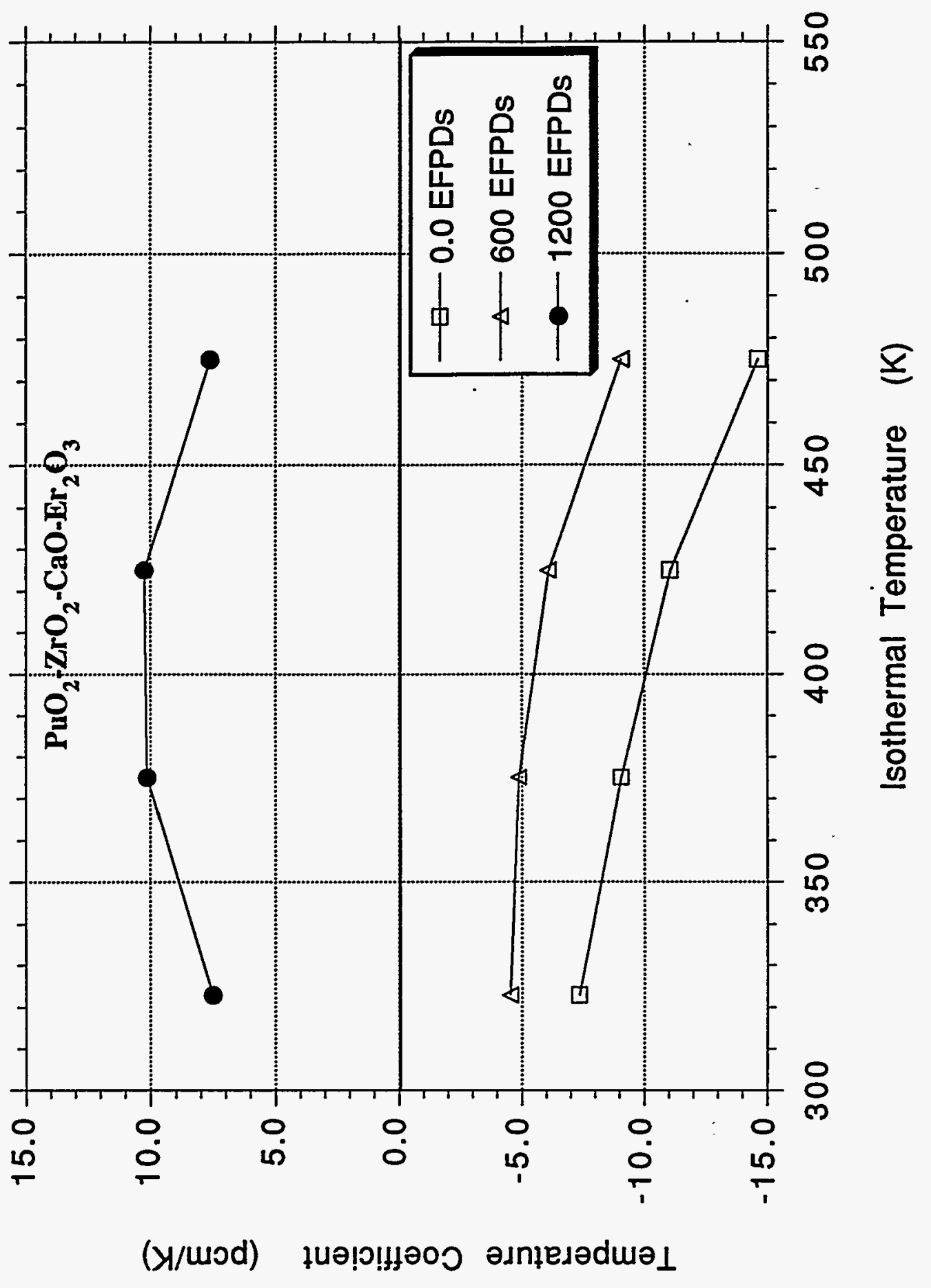

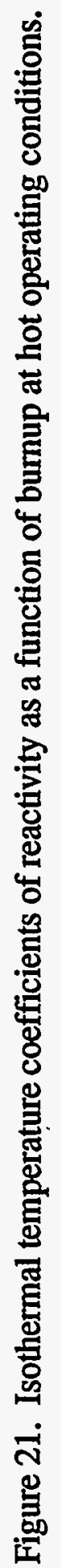




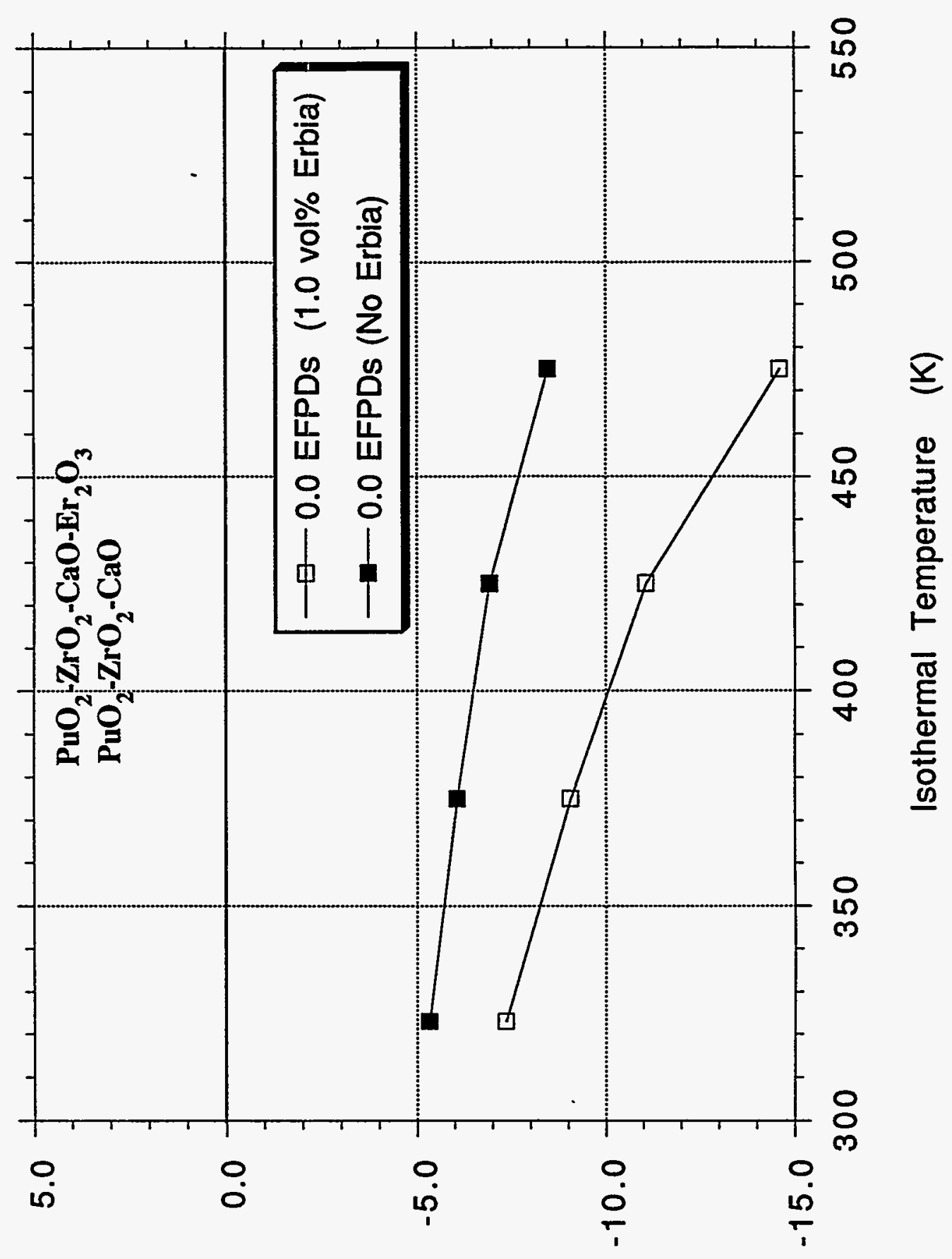

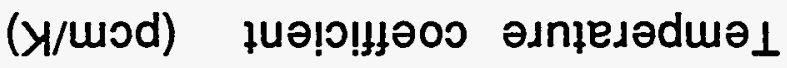

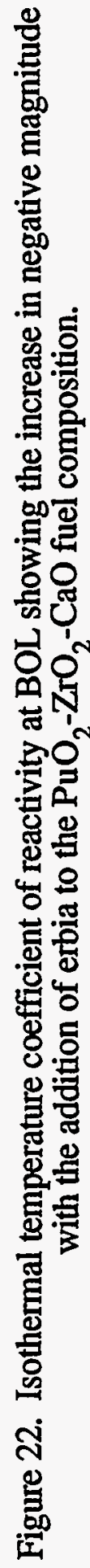


PWR fuel rod case in which the isothermal coefficients were positive. In addition, Figure 22 also shows the effect of adding erbia $(1.0 \mathrm{vol} \%)$ to the $8.41 \mathrm{wt} \% \mathrm{PuO}_{2}$ fuel. Erbia clearly increases the negative magnitude of the ITCs, however, the plutonia loading in the fuel rod appears to be the major parameter effecting the ITC.

Apparently the higher $\mathrm{PuO}_{2}$ loadings (e.g. $8.41 \mathrm{wt} \%$ ) produce some self-shielding or spectral effects that cause the isothermal temperature coefficients to be negative and as burnup occurs and the $\mathrm{PuO}_{2}$ concentration decreases (the erbia concentration also decreases), the ITCs tend to become more positive until near EOL the coefficients actually do become positive. The positive coefficients for heavily burned assemblies may be of some operational concern for cold startup conditions, but can easily be overcome by keeping the core rodded with sufficient negative hold down reactivity until the operational saturation temperatures are reached, then the negative steam void coefficient of reactivity would take over as the dominant feedback mechanism.

\subsection{Pellet Radial Power Distribution Comparison}

Two experimentally measured BOL LWR fuel pellet radial power distributions ${ }^{31}$ are compared to our calculated $\mathrm{PuO}_{2}-\mathrm{ZrO}_{2}-\mathrm{CaO}-\mathrm{Er}_{2} \mathrm{O}_{3}$ fuel pellet radial power distribution at BOL. The two LWR fuels are $\mathrm{UO}_{2}$ and $\mathrm{UO}_{2}-\mathrm{Gd}_{2} \mathrm{O}_{3}$. The three radial power distributions are plotted as point-toaverage power density versus pellet radius and are shown on Figure 23.

The $\mathrm{UO}_{2}$ power profile has the smoothest power distribution of three fuel types and will produce the least amount of thermal stress on the fuel pellet. The addition of $\mathrm{Gd}_{2} \mathrm{O}_{3}$ to the $\mathrm{UO}_{2}$ fuel is designed to extend the fuel burnup and maximize pellet power output. The large absorption cross section of ${ }^{157} \mathrm{Gd}$ self-shields the pellet interior, forcing pellet burnup to proceed from the pellet edge to the interior over time. The $\mathrm{UO}_{2}-\mathrm{Gd}_{2} \mathrm{O}_{3}$ fuel, however, has the highest point-to-average variation near the pellet edge (BOL), which leads to significant pellet thermal stress and potential cracking over the fuel burnup lifetime. Our $\mathrm{PuO}_{2}-\mathrm{ZrO}_{2}-\mathrm{CaO}-\mathrm{Er}_{2} \mathrm{O}_{3}$ fuel however has a relatively smooth radial pellet power distribution comparable to that of the UO 2 fuel.

\subsection{Cross Section Variation with Burnup}

The neutron cross sections of the major plutonium isotopes $\left({ }^{239} \mathrm{Pu},{ }^{240} \mathrm{Pu}\right.$, and ${ }^{241} \mathrm{Pu}$ ) and the burnable poison erbium isotope (167 Er) undergo significant change over the fuel burnup lifetime. One-group spectrum-averaged fission and capture cross sections are calculated for selected fuel nuclides. Figure 24 shows the fission and capture cross section variation with burnup for the three major plutonium isotopes: ${ }^{239} \mathrm{Pu},{ }^{240} \mathrm{Pu}$, and ${ }^{241} \mathrm{Pu}$. Figure 25 shows the capture cross section

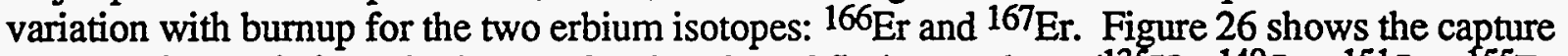

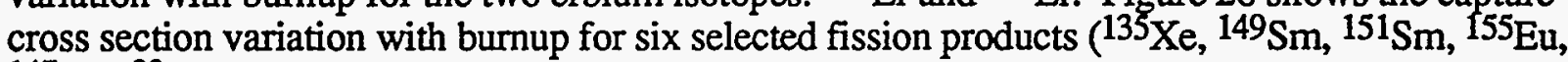
$\left.{ }^{147} \mathrm{Pm},{ }^{99} \mathrm{Tc}\right)$. Results are for the $40 \%$ moderator steam void and $6.0 \mathrm{~kW} / \mathrm{ft}$ case.

The general cross section trend is an increase in magnitude with increasing burnup. This is probably the result of a decrease in the self-shielding of the fuel pellet by plutonium and erbium and spectrum softening. The large magnitude increase in the ${ }^{239} \mathrm{Pu}$ and $241 \mathrm{Pu}$ fission cross sections relative to the capture cross sections would tend to increase the fuel reactivity which would in turn help to extend the fuel burnup. However, this benefit appears to be offset somewhat by the increase in all the fuel constituent capture cross sections as well. The increase in the capture cross sections of the fission products towards EOL would tend to burn down the fission product concentrations. This is particularly true for those fission products with very large capture cross sections (e.g. ${ }^{135 X e},{ }^{149} \mathrm{Sm},{ }^{151} \mathrm{Sm},{ }^{147} \mathrm{Pm}$ ). Fission products (and actinides and burnable poisons) with cross sections of a few barns or less tend to continue to build up over the fuel burnup lifetime. Unfortunately, the few-bam fission product nuclides include most of the long-lived fission 


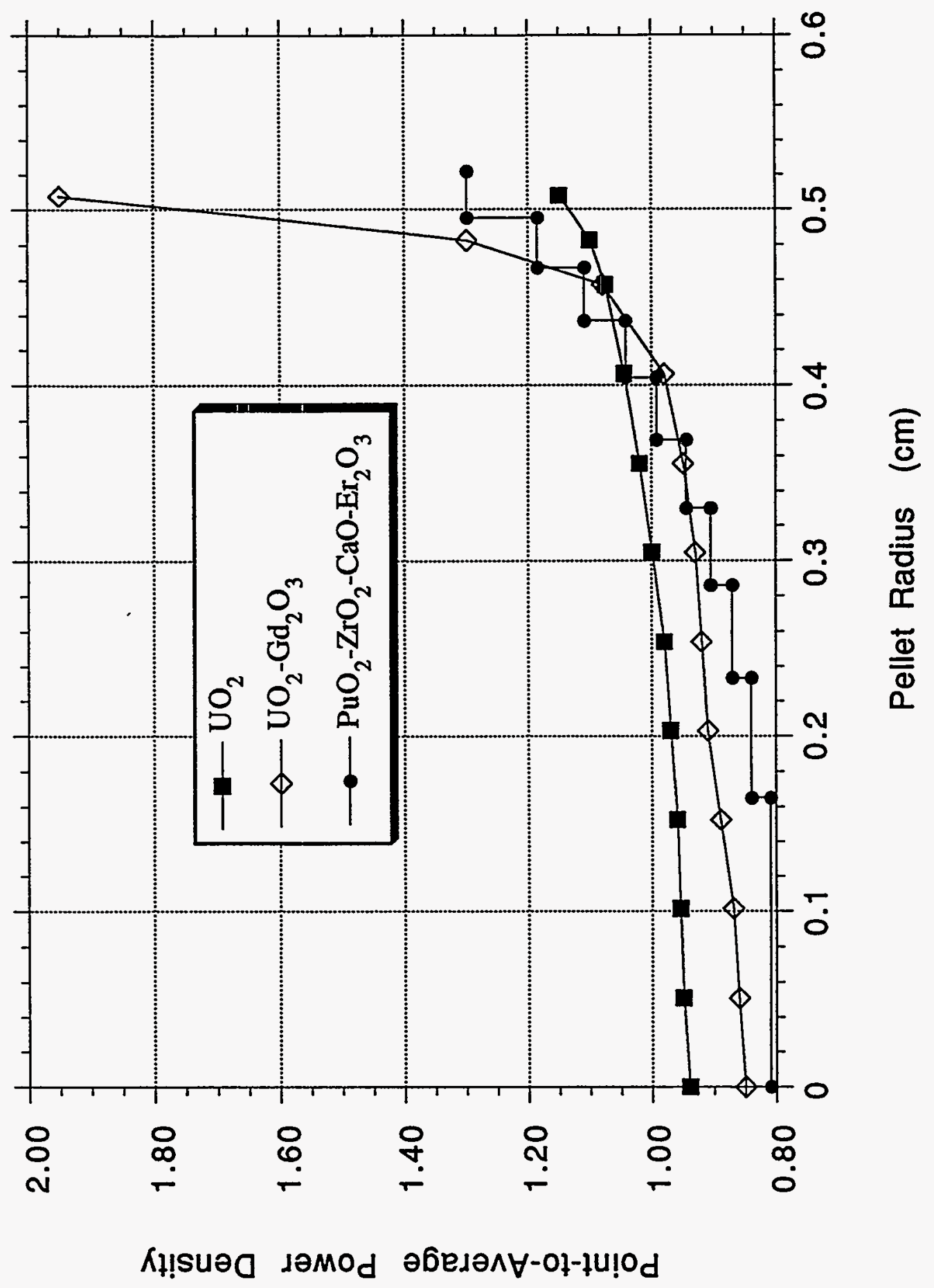

0
0
0
1
0
0
0
0
0

吕

造

o $0^{m}$

क्ष

นี

景

曷

A

을

急

可

홍

$\Xi$

茨

号

กิ

氜 


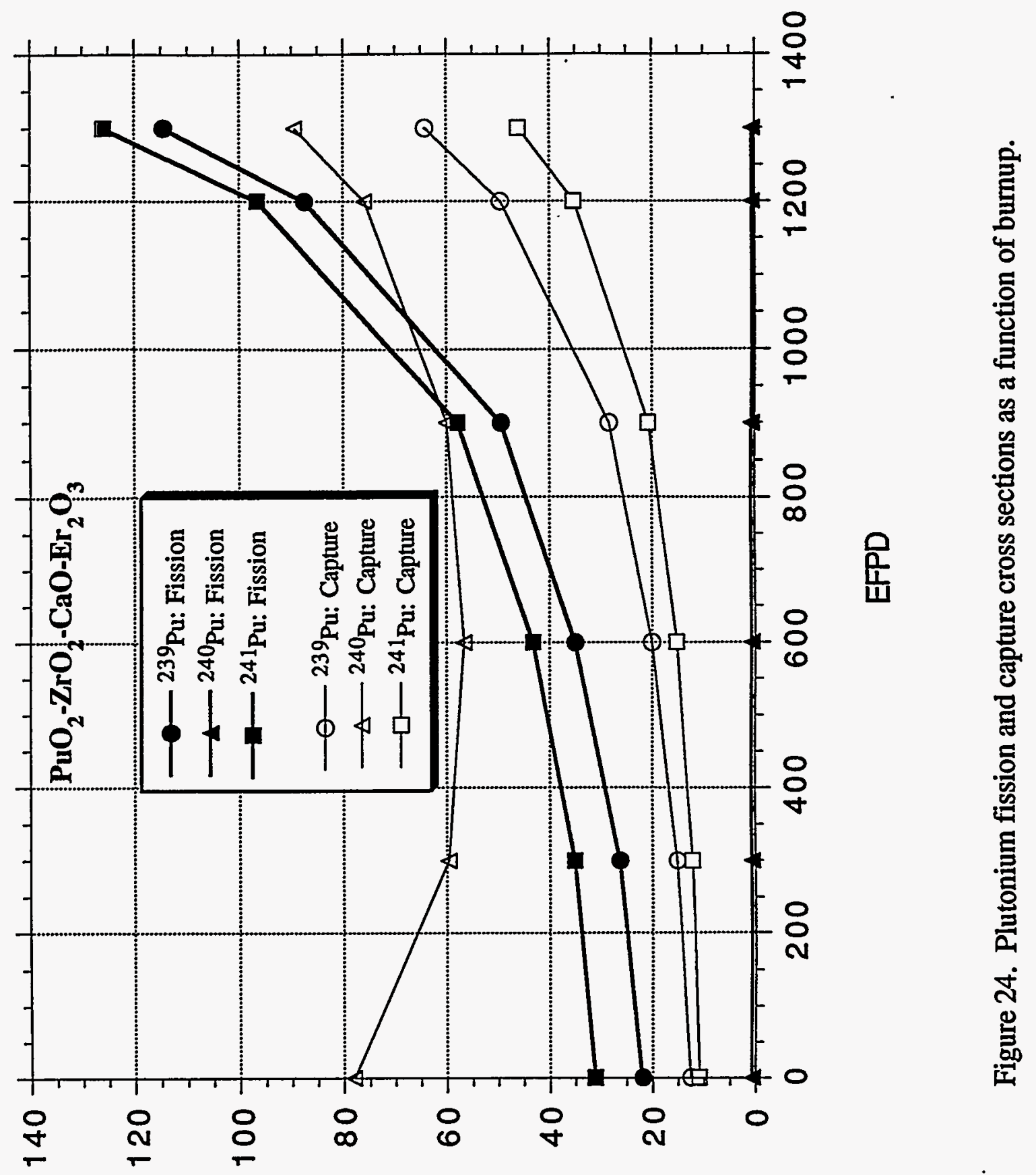

(sujeq) uo!̣oəs ssodo 


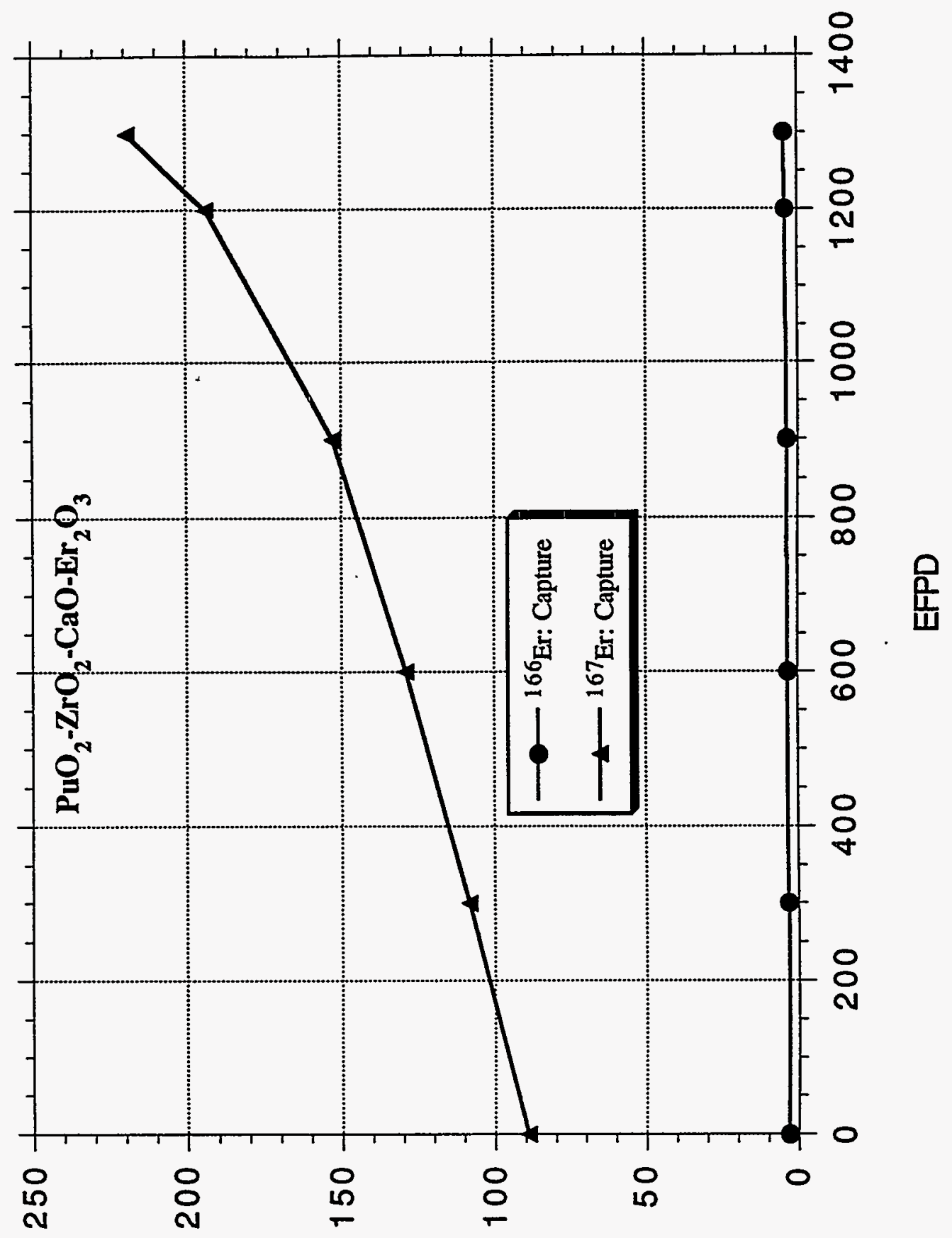

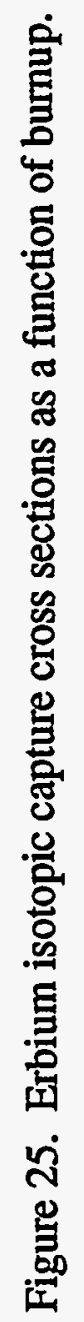

(suleq) uo!̣ors ssodo 


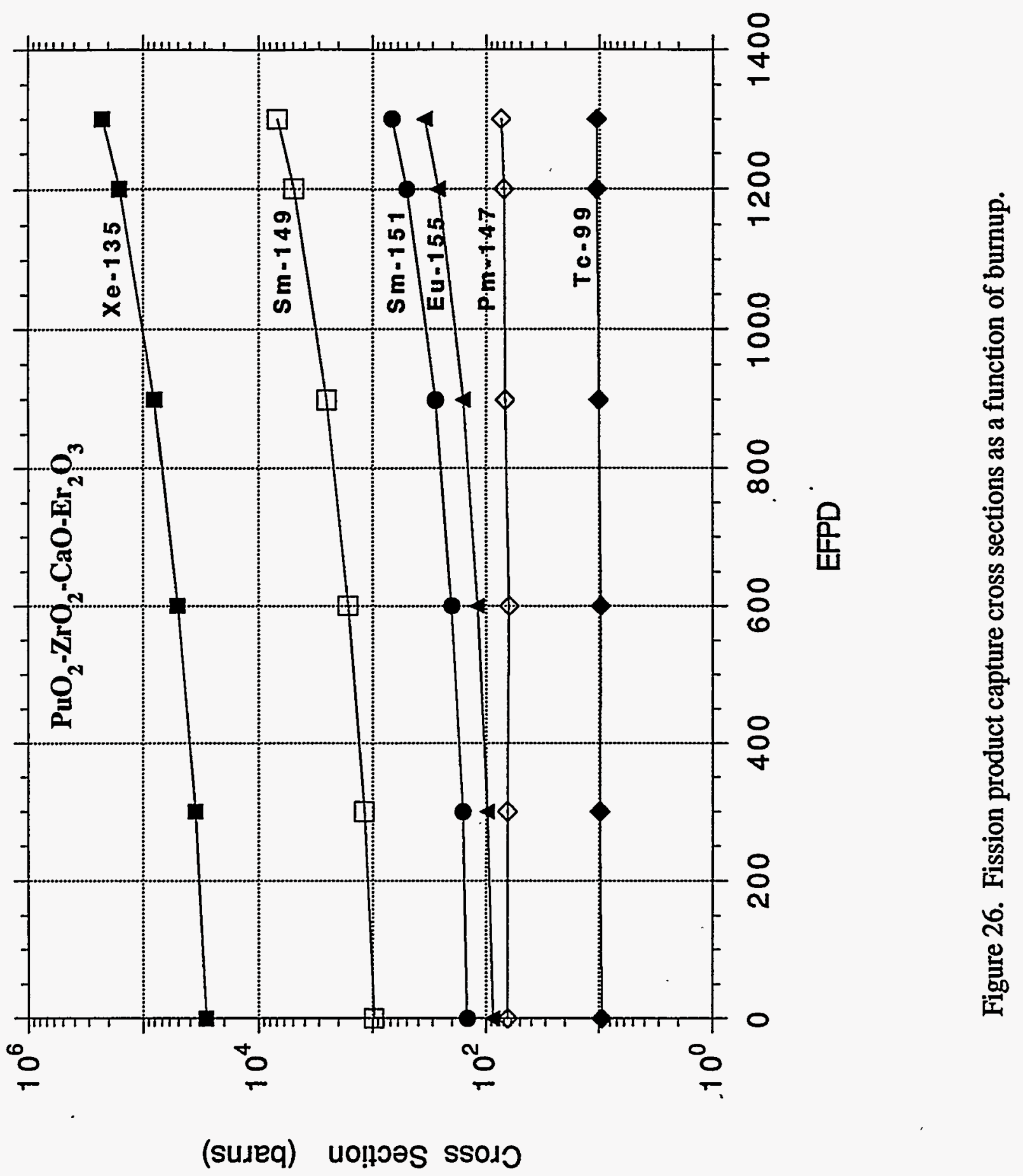


products. Figure 27 shows the gram masses per fuel rod of the six selected fission products as a function of burnup (EFPD). 


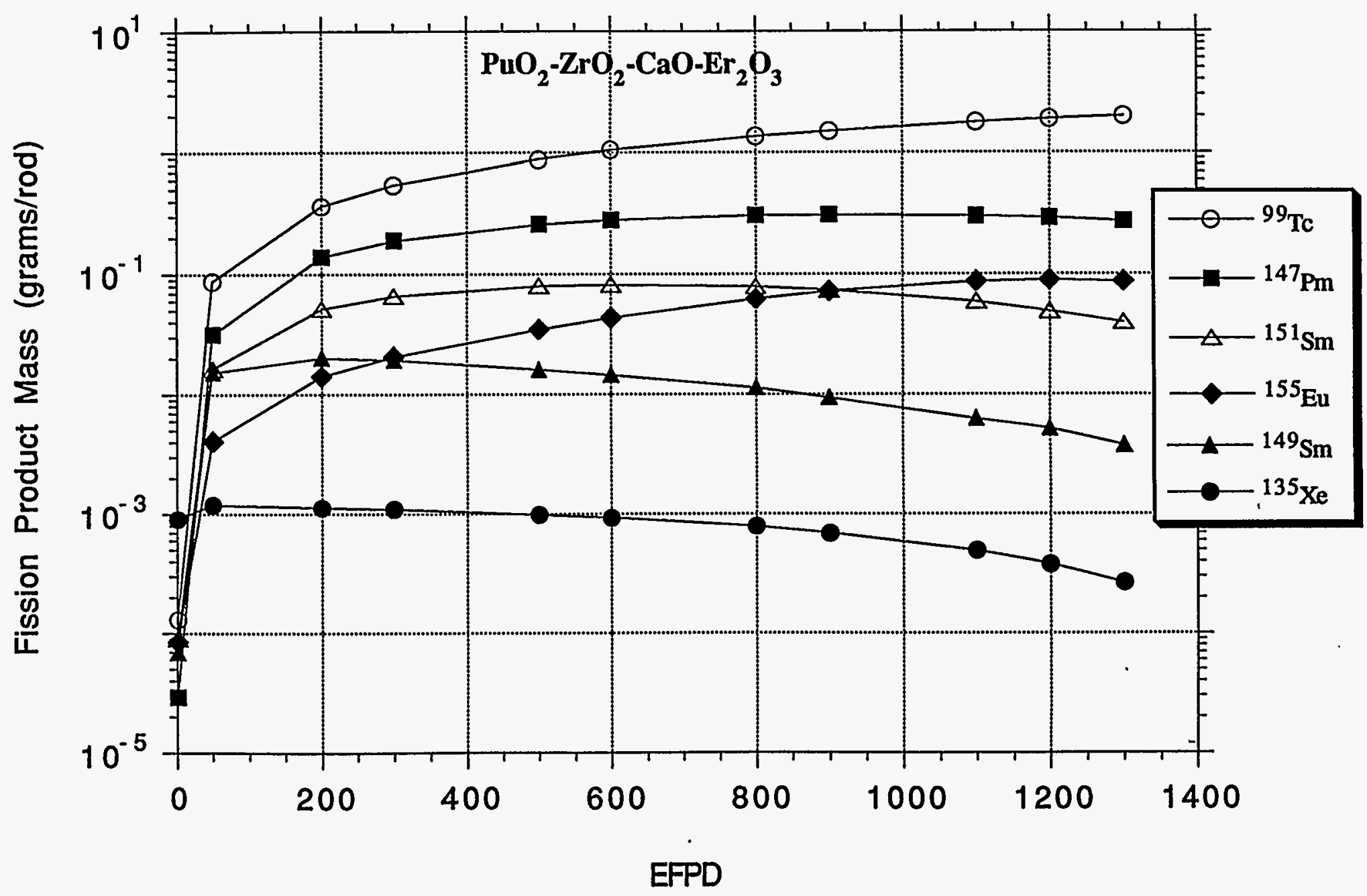

Figure 27. Fission product mass as a function of burnup. 


\subsection{CONCLUSIONS}

The non-fertile, weapons-grade $\mathrm{PuO}_{2}-\mathrm{ZrO}_{2}-\mathrm{CaO}-\mathrm{Er}_{2} \mathrm{O}_{3}$ fuel composition exhibits very favorable infinite lattice neutronic characteristics in an boiling water reactor environment using the General Electric 8x8 Advanced Boiling Water Reactor fuel assembly dimensions and pitch. This fuel composition should be considered as a strong potential candidate fuel form for light water reactor "deep burn" applications.

Plutonium destruction of between $60-73 \%$ of the initial plutonium mass in a fuel rod can be achieved before the fuel lattice goes subcritical. The percent destruction is given as a range because of the dependence on the axial variation of the moderator steam void in the BWR core, but would be weighted towards the higher end because the bulk of the BWR core contains light water with $0-40 \%$ steam void where the maximum destruction is $71-73 \%$. For an $8.3 \mathrm{wt} \% \mathrm{PuO}_{2}$ loading in our $\mathrm{PuO}_{2}-\mathrm{ZrO}_{2}-\mathrm{CaO}-\mathrm{Er}_{2} \mathrm{O}_{3}$ fuel composition, approximately $8.45 \mathrm{~kg}$ Pu metal can be loaded into the GE 8x8 fuel assembly (assuming 64 fuel rods and no radial zoning) at BOL, and after burnup assuming a $70 \%$ destruction, would contain approximately $2.54 \mathrm{~kg} \mathrm{Pu}$. At a linear heat generation rate of 6.0 or $12.0 \mathrm{~kW} / \mathrm{ft}$, the fuel rods would burn for approximately 1200 and $600 \mathrm{EFPD}$, respectively.

Total plutonium destruction in excess of the calculated 60-73\% should be possible with an efficient fuel management scheme, for example, a checkerboard loading pattern. High reactivity fuel assemblies (fresh fuel) placed next to subcritical, low reactivity fuel assemblies (burned fuel assemblies) can drive the subcritical assemblies to higher burnups. The calculated $60-73 \%$ destruction is based on the assumption that fuel assembly burnup terminates when the $\mathrm{k}_{\text {inf }}=1.0$ point is reached. Actual total plutonium destruction could be as high as $80-85 \%$ for a checkerboard-type fuel management scheme.

The $\mathrm{PuO}_{2}-\mathrm{ZrO}_{2}-\mathrm{CaO}-\mathrm{Er}_{2} \mathrm{O}_{3}$ prompt fuel Doppler coefficients of reactivity are negative over the entire fuel burnup for moderator steam voids of 0,40 , and $70 \%$ and become more negative with burnup. The steam void coefficients of reactivity are strongly negative over the entire fuel burnup for the 0-90\% steam void range. The isothermal temperature coefficients (TTC) are negative at BOL and MOL, but tend to become less negative with burnup until somewhere between MOL and EOL, the coefficients become positive. The positive ITC would be a concern for the transition from cold standby to hot standby between MOL and EOL, but could easily be overcome by maintaining a sufficiently rodded core to provide the necessary negative reactivity.

Although a $\mathrm{PuO}_{2}-\mathrm{ZrO}_{2}-\mathrm{CaO}-\mathrm{Gd}_{2} \mathrm{O}_{3}$ fuel composition (gadolinium burnable poison) was not analyzed in detail, the use of gadolinia in place of erbia should not be dismissed without further study. Potentially greater plutonium destruction can be achieved over the burnup and significantly less poison mass needs to be added at BOL, which translates into cost savings.

The $\mathrm{PuO}_{2}-\mathrm{ZrO}_{2}-\mathrm{CaO}$ fuel composition without a burnable poison is not a viable fuel composition because of its high reactivity in light water at very low rod mass loadings. Consequently, the fuel rods at commercial power levels would experience premature burnout. A burnable parasitic rareearth resonant absorber poison must be added to this composition to hold down excess reactivity, allow for adequate plutonia loadings, achieve acceptable cycle lengths and plutonium destruction, and to improve the Doppler coefficients. Thus, the evolution to $\mathrm{PuO}_{2}-\mathrm{ZrO}_{2}-\mathrm{CaO}-\mathrm{Er}_{2} \mathrm{O}_{3}$ fuel composition.

Our non-fertile, weapons-grade $\mathrm{PuO}_{2}-\mathrm{ZrO}_{2}-\mathrm{CaO}-\mathrm{Er}_{2} \mathrm{O}_{3}$ fuel composition is designed for use in both a BWR and a PWR. The BWR appears to have at least two advantages over the PWR in that the moderator density change with increasing temperature provides additional negative reactivity feedback via the increase in moderator steam void, and the moderator contains no dissolved boron 
which would tend to degrade the ITCs. The PWR, on the other hand, has a relatively uniform axial moderator density that would perhaps allow for more of the core to achieve the 70-73\% plutonium destruction over the fuel burnup lifetime. 


\subsection{REFERENCES}

1. C. S. OLSEN, "Material Properties of a Non-fertile Fuel for the Disposition of Weaponsgrade Plutonium in Light Water Reactors", EG\&G Idaho, Inc., Idaho National Engineering Laboratory, October 1994.

2. J.W. STERBENTZ, C.S. OLSEN, U.P. SINHA, "Plutonium Dispositioning in Light Water Reactors: Weapons-Grade Plutonium Dispositioning," Volume 4, DOE/ID-10422, Idaho National Engineering Laboratory, U.S. DOE Idaho Field Office, June 1993.

3. D.F. NEWMAN, "Burning Weapons-grade Plutonium in Reactors," PNL-SA-21828, Pacific Northwest Laboratory, Richland, Washington, June 1993.

4. H. AKIE et al., "A New Fuel Material for Once-through Weapons Plutonium Burning," Nuclear Technology, Volume 107, August 1994.

5. M.L. BLEIBERG, W. YENISCAVICH, and R.G. GRAY, "Effects of Burnup on Certain Ceramic Fuel Materials," Sixty-fourth Annual Meeting Papers, Symposium of Radiation Effects in Refractory Fuel Compounds, June 1961, p.64-85.

6. R.M. BERMAN, M.L.BLEIBERG, and W.YENISCAVICH, "Fission Fragment Damage to Crystal Structures," Journal of Nuclear Materials 2, No.2 (1.960) 129-140.

7. A. BOLTAX et al., "Ternary Fuel Performance Data for the Special Water Reactor," WSR-84-252, Westinghouse Electric Corporation Advanced Energy Systems Division, December 1984.

8. H.R. WARNER, "Evaluation of Low Density Single-Phase Cubic $\mathrm{ZrO}_{2}+\mathrm{UO}_{2}$ Fuels Stabilized with CaO," WAPD-292, UC-25: Metals, Ceramics, and Materials, TID-4500 (46 th Edition), January 1966, Westinghouse Electric Corporation.

9. R.M. BERMAN, "The Homogenization and Densification of $\mathrm{ZrO}_{2}+\mathrm{UO}_{2}$ Fuels Under Irradiation," WAPD-301, UC-25: Metals, Ceramics, and Materials, TID-4500 (46 th Edition), January 1966, Westinghouse Electric Corporation.

10. B.F. RUBIN, R.M. BERMAN, M.L.BLEIBERG, "The Irradiation Behavior of $\mathrm{ZrO}_{2}+$ $\mathrm{UO}_{2}$ Fuels," WAPD-264, UC-25: Metals, Ceramics, and Materials, TID-4500 (17 th Edition), October 1962, Westinghouse Electric Corporation.

11. "Management and Disposition of Excess Weapons Plutonium," Committee on International Security and Arms Control, The National Academy of Sciences, National Academy Press, Washington D.C., 1994.

12. "Study of Pu Consumption in Advanced Light Water Reactors: Evaluation of GE Advanced Boiling Water Reactor Plants," RFP DE-AC03-93SF19681, General Electric Nuclear Energy, San Jose ,California, May 13, 1993.

13. J. CARSON MARK, "Explosive Properties of Reactor-Grade Plutonium," Science \& Global Security, Volume 3, 1992. 
14. N.J. NICHOLAS, K.L. COOP, and R.J ESTOP, "Capability and Limitation Study of DDT Passive-Active Neutron Waste Assay Instrument," Los Alamos National Laboratory, LA12237-MS, 1992.

15. "Chart of the Nuclides," Nuclides and Isotopes, 14th edition, General Electric Company, Nuclear Energy Operations, San Jose, 1989.

16. "Handbook of Chemistry and Physics," Chemical Rubber Company, 51 th edition, 1972.

17. "J.A. BUCHOLZ, et al., "Standard Composition Library," NUREG/CR-200, Revision 4, Volume 3, Section M8, ORNL/NUREG/CSD-2/N-3/R4, February 1987.

18. "Final Safety Analysis Report for the Power Burst Facility," ANCR-1011, Aerojet Nuclear Co., Idaho Falls, Idaho, July 1971.

19. B.L RUSHTON and W.R. CARPENTER, "Methods used for Physics Analysis of the Power Burst Facility and Computed Results for the Design Core," ANCR-1008, July 1971, Aerojet Nuclear Company.

20. J.H. KEENAN, et al., "Steam Tables: Thermodynamic Properties of Water Including Vapor, Liquid, and Solid Phases," Publisher: John Wiley \& Sons, Inc., 1969.

21. "MCNP 4A: Monte Carlo N-Particle Transport Code System," LA-12625M, contributed by Los Alamos National Laboratory, Los Alamos, New Mexico, 1994 and distributed as package CCC- 200 by Oak Ridge National Laboratory.

22. R.A. GRIMESEY et al., April 1990, COMBINE/PC - A Portable ENDF/B Version 5 Neutron Spectrum and Cross Section Generation Program, EGG-2589, Idaho National Engineering Laboratory.

23. W.Y. YOON, “COMBINE-6 CYCLE 1", internal letter report WYY-01-94, January 17, 1994, EG\&G Idaho, Inc., Idaho National Engineering Laboratory.

24. A.G. CROFF, ORIGEN2 -- A Revised and Updated Version of the Oak Ridge Isotope Generation and Depletion Code, ORNL-5621, Oak Ridge National Laboratory, Oak Ridge, TN, July 1980.

25. R.S. BABCOCK, D.E. WESSOL, C.A. WEMPLE, S.C. MASON, "The MOCUP Interface: A Coupled Monte Carlo/Depletion System”, EG\&G Idaho, Inc., Idaho National Engineering Laboratory, presented at the 1994 Topical Meeting on Advances in Reactor Physics, Vol. III, Knoxville, TN, April 11-15,1994. .

26. R.E. MACFARLANE, D.W. MUIR, and R.M. BOICOURT, "The NJOY Nuclear Data Processing System," Vol. I: User's Manual, LA-9303-M (ENDF-324), Los Alamos National Laboratory, May 1982.

27. R.E. MACFARLANE, D.W. MUIR, and R.M. BOICOURT, "The NJOY Nuclear Data Processing System," Vol. II: The NJOY, RECONR, BROADR, HEATR, and THERMR Modules, LA-9303-M (ENDF-324), Los Alamos National Laboratory, May 1982.

28. J.J DUDERSTADT and L.J. HAMILTON; "Nuclear Reactor Analysis", copyright 1976, publisher John Wiley \& Sons, Inc. 
29. H.C. PAXTON and N.L. PROVOST, "Critical Dimensions of Systems Containing 235U, ${ }^{239} \mathrm{Pu}$, and 233 U", 1986 Revision, LA-10860-MS, UC-46, Los Alamos National Laboratory, Los Alamos, New Mexico.

30. A.W. KRAMER, "Boiling Water Reactors", Argonne National Laboratory, AddisonWesley Publishing Company, Inc., September 1958.

31. "Urania Gadolinia: Nuclear Model Development and Critical Experiment Benchmark", BAW-1810, prepared for the U.S. Department of Energy, DOE/ET/34212-41, April 1984, UC-78 by Babcock \& Wilcox. 


\section{APPENDIX A}

\section{FUEL ATOMIC NUMBER DENSITIES}




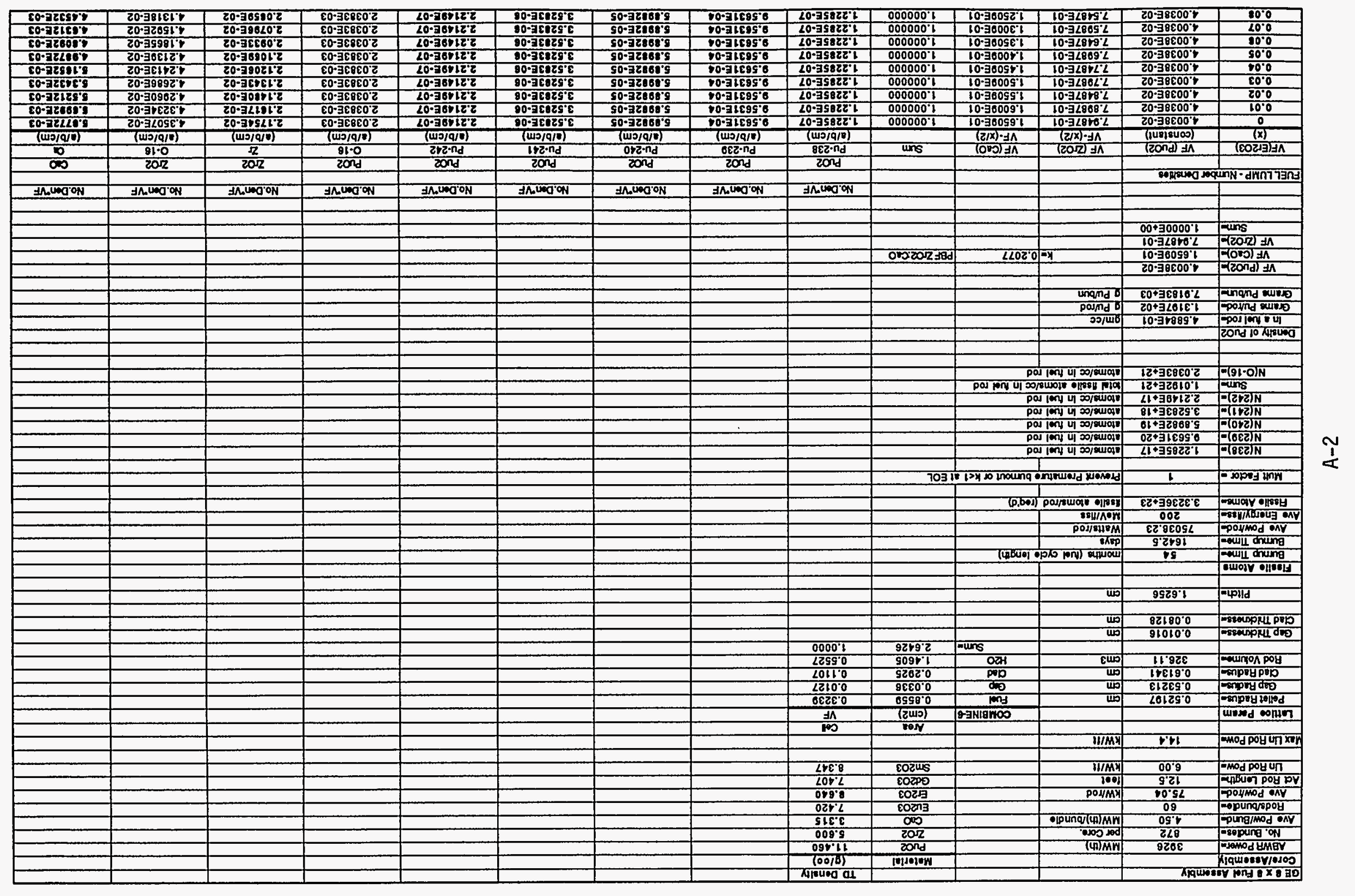




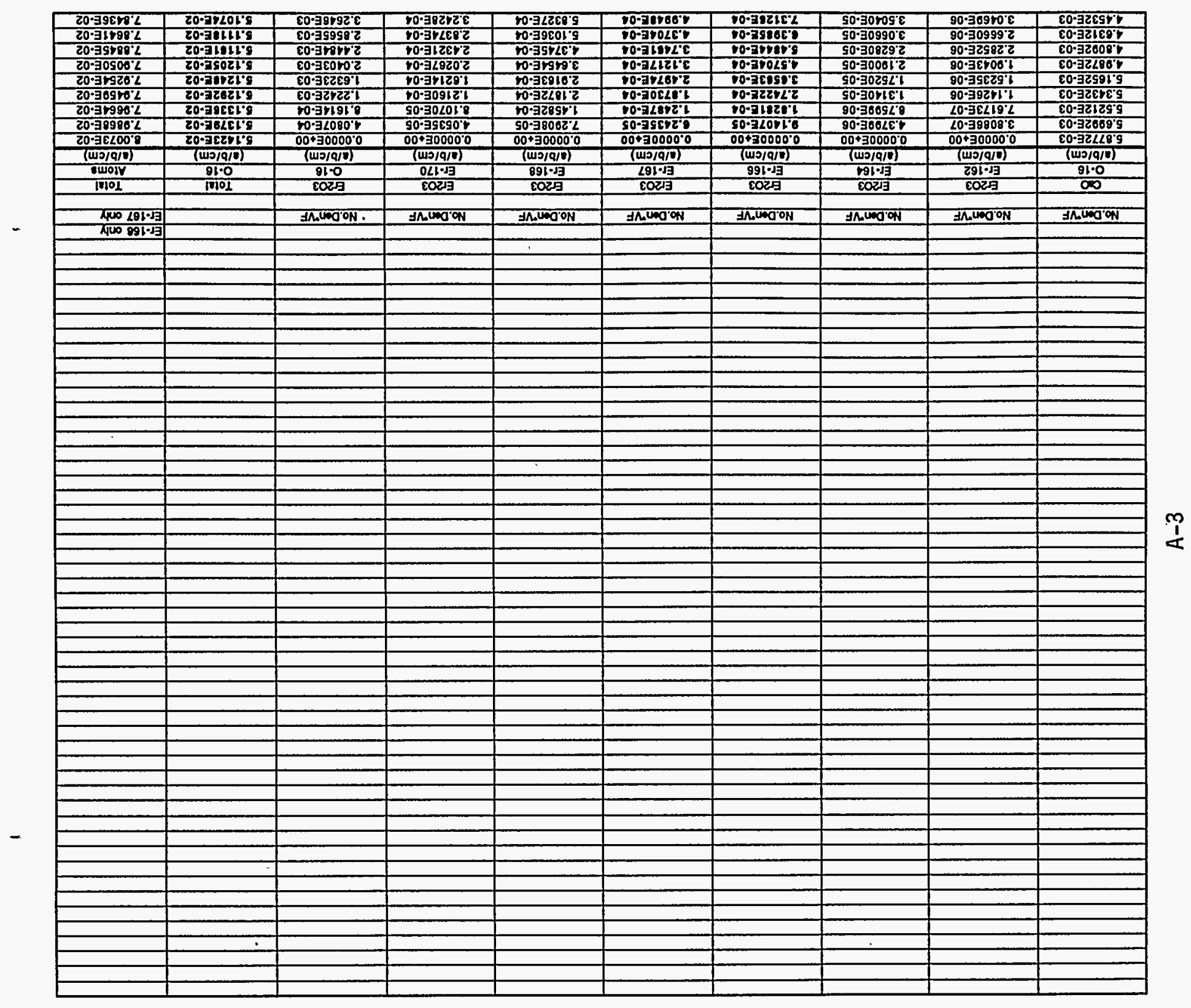




\begin{tabular}{|c|c|c|c|c|c|c|c|c|c|c|c|c|c|}
\hline 0.00 & $4.0038 \mathrm{E} \cdot 02$ & 7.4087E.01 & $1.2000 \mathrm{E}-01$ & 1.000000 & $1.2205 \mathrm{E} \cdot 07$ & $8.5631 \mathrm{E} .04$ & $5.8922 \mathrm{E}-05$ & $3.5203 \mathrm{E} \cdot 06$ & $2.21402-07$ & $2.0383 \mathrm{E} \cdot 03$ & $2.0522 E=02$ & 4.104AE.02 & $4.2752 E-0.3$ \\
\hline \multirow{2}{*}{\multicolumn{2}{|c|}{ FELL LUMP. Grams }} & & & & Gramefrod & Gramarod & Gramsfod & Grams/rod & Crimstod & Qramsirod & Cramshod & Gramz/rod & Gramatrod \\
\hline & & & & & PUO2 & PLO2 & PUOR & PLO2 & PUOR & Pro2 & 202 & 202 & $\infty_{0}$ \\
\hline VF(EURO3) & VF (PUO2) & VF $(\mathrm{ZrO} 2)$ & VF $\left(\mathrm{CAO}^{\prime}\right.$ & sum & PU-238 & PU.239 & Pu.240 & Pu.241 & Pu.242 & 0.16 & 7 & 0.16 & $a$ \\
\hline$\frac{(x)}{(x)}$ & (constan!) & $\overline{V F \cdot(x / 2)}$ & $\mathrm{VF}_{\mathrm{F} \cdot(\mathrm{x} / \mathrm{x})}$ & & (gram/rod) & (gram/rod) & (gram/rod) & (pram/rod) & (gramifod) & (gremurod) & (gram/rod) & (gram/rod) & (gram/rod) \\
\hline 0 & $4.0038 E .02$ & $7.0487 \mathrm{E} \cdot 01$ & $1.6500 \mathrm{E} \cdot 01$ & 1.000000 & $1.5837 \mathrm{E} .02$ & $1.2380 E+02$ & $7.6675 E+00$ & $4.6058 \mathrm{EE} \cdot 01$ & $2.8034 E .02$ & $1.7660 E+01$ & $1.0746 E+03$ & $3.7606 E+02$ & $1.2756 E+02$ \\
\hline 0.01 & $4.0038 \mathrm{E} .02$ & $7.8087 \mathrm{E}-01$ & $1.6000 \mathrm{E}-01$ & 1.000000 & $1.5837 \mathrm{E} .02$ & $1.2300 E+02$ & $7.6875 E+00$ & $4.6058 E .01$ & 2.0034E-02 & $1.7660 E_{0} 01$ & $1.0670 E+03$ & $3.7459 E+02$ & $1,2360 E_{4} 02$ \\
\hline 0.02 & $4.0038 \mathrm{E} \cdot 02$ & $7.8487 E .01$ & $1.5500 \mathrm{E} \cdot 01$ & 1.000000 & $1.5837 \mathrm{E}-02$ & $1.2300 E+02$ & $7.6675 E+00$ & $4.6058 E .01$ & 2.0034E.02 & $1.7660 E+01$ & $1.0611 E+03$ & $3.7221 E+02$ & $1.10 B 3 E_{4} 02$ \\
\hline 0.03 & $1.0038 \mathrm{E} \cdot 02$ & $7.7087 \mathrm{E} .01$ & $1.5000 \mathrm{E} \cdot 01$ & 1.000000 & $1.5837 \mathrm{E} \cdot 02$ & $1.2360 E+02$ & $7.6675 E+00$ & $4.6058 \mathrm{E}-01$ & $2.0034 E .02$ & $1.7660 \mathrm{E}+01$ & $1.0544 E+03$ & $3.6984 \mathrm{~A}+02$ & $1.1507 E+02$ \\
\hline 0.04 & 1.003BE.02 & $7.7487 \mathrm{E} .01$ & $1.4500 \mathrm{E} \cdot 01$ & 1.000000 & $1.5837 \mathrm{E} .02$ & $1.2380 E+02$ & $7.6675 E+00$ & $4.6058 E-01$ & $2.0034 E .02$ & $1.7660 \mathrm{E}+01$ & $1.0476 E+03$ & $3.6747 E+02$ & $1.1210 E+02$ \\
\hline 0.05 & $4.0038 \mathrm{E} .02$ & $7.6087 \mathrm{E}-01$ & 1.4000E-01 & 1.000000 & $1.5837 \mathrm{E} .02$ & $1.23800+02$ & $7.6675 E+00$ & $4.6058 \mathrm{EE}-01$ & $2.0034 \mathrm{E} .02$ & $1.7660 E+01$ & $1.0400 E+03$ & $3.6510 E+02$ & $1.0824 E+02$ \\
\hline 0.06 & $4.0038 E=02$ & $7.6487 \mathrm{E} \cdot 01$ & $1.3509 \mathrm{E} \cdot 01$ & 1.000000 & $1.5837 \mathrm{E} .02$ & $1.2300 E+02$ & $7.6675 E+00$ & $4.6058 \mathrm{E} .01$ & 2.0034 E.02 & $1.7660 E+01$ & $1.0341 E+03$ & $3.6273 \mathrm{E}+02$ & $1.0438 E+02$ \\
\hline 0.07 & $4.003 B E=02$ & $7.5987 E \cdot 09$ & $1.3000 \mathrm{E} \cdot 01$ & 1.000000 & $1.5837 \mathrm{E} .02$ & $1.2300 \mathrm{E}+02$ & $7.6675 E+00$ & $4.605 \mathrm{BE} \cdot 01$ & $2.9034 \mathrm{E} .02$ & $1.7660 E+01$ & $1.0273 E+03$ & $3.6036 \mathrm{E}+02$ & $1.0051 E+02$ \\
\hline \multirow{4}{*}{0.00} & $4.0038 \mathrm{E} \cdot 02$ & $7.5467 E .01$ & $1.2509 \mathrm{E} \cdot 01$ & 1.000000 & $1.6837 \mathrm{E} .02$ & $1.2300 E+02$ & $7.6675 E+00$ & A.6058E.01 & 2.0034E.02 & $1.7660 \mathrm{E}+01$ & $1.0206 \mathrm{E}+03$ & $3.5700 E \div 02$ & $0.6651 E+01$ \\
\hline & $1.0038 \mathrm{E} \cdot 02$ & $7.4987 E .01$ & $1.2000 \mathrm{E} \cdot 01$ & 1.000000 & 1.5837E-02 & $1.2380 E+02$ & $7.6676 \mathrm{E}+00$ & 4.6058E-01 & 2.003 सE.02 & $1.7660 \mathrm{E}+01$ & $1.0138 E+03$ & $3.5562 E+02$ & $0.27076+01$ \\
\hline & & & & & & & & & & & & & \\
\hline & & & & & wolght frection & wolght fraction & wolght raction & wolght traction & wolght traction & wolght frection & woight treetion & wolght reation & welght frection \\
\hline \multicolumn{2}{|c|}{ FUEL LUMP. Woldhi Trestons } & & & & & & & & & & & & - \\
\hline VF(EURO3) & VF (PUOZ) & VF (ZOO2) & VF (GAO) & sum & $\frac{\text { PUOZ }}{\text { PU.23B }}$ & $\frac{\text { PuO2 }}{\text { Pu.230 }}$ & $\frac{\text { PuOR }}{\text { Pu.210 }}$ & $\begin{array}{c}\mathrm{PLO2} \\
\mathrm{Pu} \cdot 241\end{array}$ & $\frac{\text { Puce }}{\text { Pu.242 }}$ & $\begin{array}{l}\text { PLO2 } \\
0.16\end{array}$ & $\frac{202}{z}$ & $\frac{2.02}{0.16}$ & $\frac{c o p}{a}$ \\
\hline$\frac{(x)}{(x)}$ & (constani) & $\mathrm{VF} \cdot(\mathrm{x} / \mathrm{2})$ & $V F \cdot(x / 2)$ & & (wt. trac.) & (Wt. Hac.) & (m. Irac.) & (wt. frac.) & (m. Hece.) & (mt. toc.) & (m. hac.) & prt. kac. & (m. trec.) \\
\hline 0 & $1.0038 E-02$ & $7.0487 E .01$ & $1.6508 \mathrm{E} .01$ & 1.000000 & $8.8084 E \cdot 06$ & 6.956 IE.02 & 1.3083E-03 & $2.5870 \mathrm{E}-04$ & $1.6314 E \cdot 05$ & $0.0232 E-03$ & $6.03 \mathrm{~B} 3 \mathrm{E} \cdot 01$ & $2.1181 E \cdot 01$ & $7.1672 E \cdot 02$ \\
\hline 0.01 & $1.0038 E-02$ & $7.8087 E-01$ & $1.6009 \mathrm{E}-01$ & 1.000000 & $8.8307 \mathrm{E}-06$ & 6.90325 .02 & $4.2755 \mathrm{E} \cdot 03$ & $2.5683 E .04$ & $1.6100 \mathrm{E} \cdot 05$ & $9.8477 \mathrm{E} \cdot 03$ & $5.9547 \mathrm{E} .01$ & $2.08 B 7 E \cdot 01$ & $6.8073 \mathrm{E}-02$ \\
\hline 0.02 & 4.0038E.02 & 7.8487E-01 & $1.5509 \mathrm{E} \cdot 01$ & 1.000000 & $8.7640 \mathrm{E} \cdot 06$ & $6.8511 E .02$ & $4.2433 E \cdot 03$ & $2.54 \mathrm{BOE}-04$ & $1.6067 E-05$ & 0.7734E.03 & $5.8723 E .01$ & $2.0509 E .01$ & 6.6314 E. 02 \\
\hline 0.03 & 4.0038E-02 & 7.7087E.01 & $1.5000 \mathrm{E} \cdot 01$ & 1.000000 & 8.6084E.06 & 6.7907E.02 & $4.2115 E .03$ & 2.5208E.04 & 1.5947E.05 & $0.7002 E \cdot 03$ & $5.7012 \mathrm{E} \cdot 01$ & 2.0314E-01 & $8.3605 E \cdot 02$ \\
\hline 0.04 & $4.0038 E-02$ & $7.7467 E .01$ & 1.4509E.01 & 1.000000 & $8.6337 \mathrm{E} .06$ & 6.7402E.02 & 4.1802E.03 & 2.5110 E.04 & 1.5828E.05 & $0.6280 \mathrm{E} \cdot 03$ & 5.7113E.01 & 2.0034E-01 & 6.1116E.02 \\
\hline 0.05 & $1.0038 E \cdot 02$ & 7.6097 E.01 & $1.4000 \mathrm{E} \cdot 01$ & 1.000000 & $8.5700 E-06$ & 6.6904E.02 & 1.1403E-03 & $2.4924 E .04$ & 1.5712E-05 & $0.55705 \cdot 03$ & 5.6326E.01 & $1.0757 \mathrm{E} .01$ & 6.8574E.02 \\
\hline 0.08 & $1.0038 E .02$ & 7.6467E-01 & $1.3509 \mathrm{E} \cdot 01$ & 1.000000 & $8.5072 E=06$ & $8.6503 E .02$ & 4.1189E.03 & $2.4742 E .04$ & $1.5507 \mathrm{E} .05$ & $0.4870 E=03$ & 6.5550E.01 & $1.0485 \mathrm{E} .01$ & $5.6070 \mathrm{E} \cdot 02$ \\
\hline 0.07 & $4.0038 E \cdot 02$ & $7.5907 \mathrm{E} .01$ & $1.3000 \mathrm{E} \cdot 01$ & 9.000000 & $8.4453 E \cdot 06$ & 6.6010E-02 & $4.0889 E \cdot 03$ & $2.4562 E .04$ & $1.5483 E-05$ & $9.4170 \mathrm{E} \cdot 03$ & $5.4785 E \cdot 01$ & 1.0217E.01 & $5.3602 E \cdot 02$ \\
\hline 0.08 & $4.0038 \mathrm{E} \cdot 02$ & $7.5487 E .01$ & $1.2500 \mathrm{E} \cdot 01$ & 1.000000 & 8.3843E-06 & $6.5542 \mathrm{E} \cdot 02$ & 1.0594E.03 & $2.4384 E-04$ & 1.5371E.05 & $0.3409 E-03$ & $5.4032 \mathrm{E} .01$ & $1.8053 \mathrm{E} .01$ & 5.1160 E. 02 \\
\hline \multirow[t]{4}{*}{0.00} & $4.0038 E \cdot 02$ & $7.4087 \varepsilon .01$ & $1.2000 E .01$ & 1.000000 & B.3242E.06 & $6.5072 E .02$ & $4.0303 \mathrm{E} \cdot 03$ & $2.1210 E .04$ & $1.5261 E .05$ & $0.2820 E-03$ & $5.3280 \mathrm{E}-01$ & 1.86025 .01 & $4.0772 E .02$ \\
\hline & & & & & & & & & & & & & \\
\hline & & & & & & & & & & & & & \\
\hline & & & & & welght percort & welght porcont & wedoht percent & wolghts parcont & & & & & \\
\hline \multicolumn{3}{|c|}{ 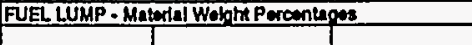 } & & & & & & & & & & & \\
\hline VF(Er) & VF (PUO2) & VF (zrO2) & VF (CAO) & gem & PLO2 & 2702 & $\infty$ & 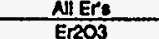 & & & & & \\
\hline$\frac{(x)}{(x)}$ & (constent) & $V F=(x / 2)$ & $V_{F} \cdot(x / 2)$ & & $\frac{(w+\%)}{(w+\%)}$ & $\frac{(w 6)}{(w+x)}$ & $(w t x)$ & $\left(w 1 x_{0}\right)$ & sum & & & & \\
\hline 0 & $4.0038 E-02$ & $7.0467 E=01$ & $1.650 \mathrm{gE} \cdot 01$ & 1.000000 & 8.41 & 81.56 & 10.03 & 0.00 & 100.00000000 & & & & \\
\hline 0.01 & $4.0038 \mathrm{BE}-02$ & $7.8067 E \cdot 01$ & $1.6000 \mathrm{E}-01$ & 1.000000 & 8.34 & 80.43 & 0.65 & 1.57 & 100.00000000 & & & & \\
\hline 0.02 & 4.0038E-02 & $7.8487 \mathrm{E} .01$ & 1.55000.01 & 1.000000 & 8.28 & 70.32 & 0.28 & 3.12 & 100.00000000 & & & & \\
\hline 0.03 & $1.0038 E .02$ & 7.7087E.01 & $1.5000 \mathrm{E} \cdot 01$ & 1.000000 & 8.22 & 78.23 & 8.91 & 4.64 & 100.00000000 & & & & \\
\hline 0.04 & $4.0038 \mathrm{E} .02$ & $7.7487 \mathrm{E} \cdot 01$ & 1.1500E-01 & 1.000000 & 8.16 & 77.15 & 8.55 & 6.14 & 100.00000000 & & & & \\
\hline 0.05 & $4.0038 \mathrm{E}=02$ & 7.6987E.0! & $1.1000 \mathrm{E} \cdot 0 \mathrm{~T}$ & 1.000000 & 8.10 & 76.08 & 8.20 & 7.62 & 100.00000000 & & & & \\
\hline 0.06 & $4.0030 \mathrm{E} .02$ & $7.6487 \mathrm{E} \cdot 01$ & $1.3500 \mathrm{E} .0 \mathrm{t}$ & 1.000000 & 8.04 & 75.04 & 7.85 & 0.08 & 100.00000000 & & & & \\
\hline 0.07 & $4.0038 \mathrm{E} \cdot 02$ & $7.5087 \mathrm{E} \cdot 01$ & $1,3000 \mathrm{E}=01$ & 1.000000 & 7.08 & 74.00 & 7.50 & 10.52 & 100.00000000 & & & & \\
\hline 0.08 & $4.0038 E \cdot 02$ & $7.5487 \mathrm{EE}-01$ & $1.2500 \mathrm{E}-01$ & 1.000000 & 7.92 & 72.98 & 7.16 & 11.03 & 100.00000000 & & & & \\
\hline \multirow[t]{2}{*}{0.08} & $4.0038 \mathrm{E}-02$ & $7.4007 \mathrm{E} .01$ & $1.2000 \mathrm{E} .01$ & 1.000000 & 7.87 & 71.08 & 6.82 & 13.33 & 100.00000000 & & & & \\
\hline & & & & & & & & & & & & & \\
\hline \multirow{3}{*}{ 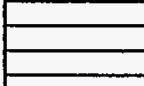 } & & & & & & & & & & & & & \\
\hline & & & & & & & & & & & & & \\
\hline & & & & & & & & & & & & & \\
\hline \multirow{2}{*}{ Fing } & & & & & MCNP-traction & MCNP-frection & MCNP. fraction & MCNP.trection & MCNPAtraction & & MCNP.frection & & MCNP-racion \\
\hline \multirow{2}{*}{\multicolumn{2}{|c|}{ EUEL LUMP - MCNP Number Donetives }} & & & & & & & & & & & & \\
\hline & & & & & PUO2 & PUO2 & PUOR & PWO2 & PUDR & PYO2 & 202 & 2702 & $\infty$ \\
\hline VF(ER2O3) & VF (PUO2) & VF $(\mathrm{zr} / \mathrm{C})$ & VF $(c s)$ & $\operatorname{sem}$ & Pu.238 & PU.239 & $P_{U} \cdot 240$ & Pu.241 & Pu-242 & 0.16 & $z$ & 0.16 & $a$ \\
\hline$(x)$ & (constent) & $\mathrm{VF} \cdot(\mathrm{x} / 2)$ & $\begin{array}{l}F \cdot(x / 2) \\
\end{array}$ & & $(\mathrm{a} / \mathrm{b} / \mathrm{cm})$ & $(\mathrm{a} / \mathrm{b} / \mathrm{cm})$ & $(\mathrm{a} / \mathrm{b} / \mathrm{cm})$ & $(\mathrm{a} / \mathrm{b} / \mathrm{cm})$ & $(\mathrm{arb} / \mathrm{cm})$ & $(\mathrm{e} / \mathrm{b} / \mathrm{cm})$ & $(\mathrm{a} / \mathrm{d} / \mathrm{cm})$ & $(\mathrm{e} / \mathrm{b} / \mathrm{cm})$ & $(\mathrm{a} / \mathrm{D} / \mathrm{cm})$ \\
\hline 0 & $1.0038 \mathrm{E}-02$ & $7.9487 E-01$ & 1.6500 E. 01 & 1.000000 & 1.5342E-08 & $1.1943 \mathrm{E}-02$ & $7.36011 E-09$ & . $.4083 E-05$ & 2.7801E.06 & & 2.7167E-01 & & $7.3308-02$ \\
\hline 0.01 & $4.0038 \mathrm{E} \cdot 02$ & $7.8087 E-01$ & $1.6000 \mathrm{E}-01$ & 1.000000 & $1.5381 \mathrm{E}-08$ & $1.1074 E-02$ & $7.31500=04$ & $0.4176 E-05$ & $2.7732 E-00$ & & $2.7068 E .01$ & & $7.13575-02$ \\
\hline 0.02 & $4.0038 E=02$ & $7.8487 E .01$ & 1.5500E-01 & 1.000000 & $1.5421 E-08$ & $1.2004 E .02$ & $7.4030 \mathrm{E} \cdot 04$ & 4.42008 .05 & $2.7103 E-08$ & & $2.6063 \mathrm{E}-01$ & & $6.0305 E-02$ \\
\hline 0.03 & $4.0038 E-02$ & $7.7087 \mathrm{E} .01$ & 1.50000 E-01 & 1.000000 & $1.5461 E \cdot 08$ & 1.2035E-02 & $7.1230 E=04$ & $4.4404 E-05$ & $2.7875 E-08$ & & $2.6861 E .01$ & & C.7244E-02 \\
\hline
\end{tabular}




\begin{tabular}{|c|c|c|c|c|c|c|c|c|c|}
\hline $4,2752 E \cdot 03$ & $3.4278 E-06$ & $3.2410 E .05$ & $. .2267 \mathrm{E}-04$ & $5.6101 E^{-04}$ & $6.5617 \mathrm{E} .04$ & $3.6481 E-04$ & $3.6726 \mathrm{E}: 03$ & $5.1030 \mathrm{E}-02$ & 7.82325 .02 \\
\hline Gramajod & Crementod & Qrams $/$ od & Gramatod & Gramsrod & Gramsiod & Gramerod & Cramstod & & \\
\hline$\frac{\infty}{0.16}$ & $\begin{array}{r}\text { E.203 } \\
\text { Er.162 } \\
\end{array}$ & Ero.164 & $\begin{array}{l}\text { Ere.03 } \\
\text { Er.166 }\end{array}$ & $\begin{array}{c}\text { ER:203 } \\
\text { Er.167 } \\
\end{array}$ & $\begin{array}{c}E_{2003} \\
\text { Er. } 168 \\
\end{array}$ & $\begin{array}{c}\text { Er:203 } \\
\text { Er.170 }\end{array}$ & $\begin{array}{c}E-203 \\
0.16 \\
\end{array}$ & $\begin{array}{l}\text { Total } \\
0.18 \\
\end{array}$ & 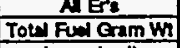 \\
\hline gremirod $)$ & (gremproos) & (gram/rod) & Gramirood) & (gramirod) & (gramirod) & $\frac{(\mathrm{gram} / \mathrm{rod})}{0.0000+00}$ & & $\frac{(\mathrm{rram} / \mathrm{rod})}{4.456402}$ & \\
\hline $5.0021 E+01$ & $\frac{0.0000 E+00}{3.3098 .02}$ & $\frac{0.0000 E+00}{3.8820 .00}$ & $\frac{0.00000=00}{8.2136 E+00}$ & $\frac{0.0000 E+00}{5.6440 E+00}$ & $\frac{0.0000 E+00}{6.03020+00}$ & $\frac{0.0000 E+00}{3.7302 E+00}$ & $\frac{0.00000+00}{3.535 E+00}$ & & $\frac{1770.71}{1703.35}$ \\
\hline$\frac{4.0397 \mathrm{E}+01}{4.7837 \mathrm{E}+01}$ & $\frac{3.33898 \cdot 0.02}{6.6796 E \cdot 02}$ & $\begin{array}{l}3.8 .8828=-01 \\
7.7764 E=01 \\
\end{array}$ & $\frac{0.6427 E+01}{1.64}$ & $1.128 B E+01$ & $\frac{.0 .3015+01}{1.3261 E+01}$ & $\begin{array}{l}\frac{3.37302++0}{7.4605 E+00} \\
\end{array}$ & $7.0712 E+00$ & 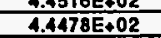 & \\
\hline$\frac{4.6294 E+01}{.1757}$ & $\frac{1.00190 .01}{1.001}$ & $1.1665 E+00$ & $2.4641 E+01$ & $1.6932 E+01$ & 1.8881E +01 & $1.1101 E+01$ & $1.0607 E+01$ & $4,4440 E+02$ & 1820.63 \\
\hline $4.4752 E+01$ & $1.3359 \mathrm{E} .01$ & $1.5553 \mathrm{E}+00$ & $3.2854 E+01$ & $2.2576 E+01$ & $2.6521 E+01$ & $1.4921 E+01$ & $1.4142 E+01$ & $4.4403 E+02$ & \\
\hline $4.3210 E+01$ & $1.66 \mathrm{cgE} \cdot 01$ & $1.9441 E+00$ & 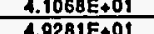 & $\frac{2.8220 E+01}{200010.01}$ & $\frac{3.3152 E+01}{307025}$ & $\frac{1.8651 E+01}{202010}$ & $\frac{1.7678 E+01}{20014501}$ & $4.4365 E+02$ & 1847.01 \\
\hline$\frac{4.1668 E+01}{40126 E+01}$ & $\frac{2.0030 E=01}{2.3770=0.01}$ & $\frac{2.33232 \mathrm{E}+00}{2.7217 \mathrm{E}+00}$ & $\frac{0.20861 E+01}{5.7405 E+01}$ & $\frac{3.50605 E+U 1}{3.0508 E+01}$ & $\frac{3.0 .9825 z+01}{1.6412 E+01}$ & $\frac{2.2381 E+01}{2.6512 E+01}$ & $\frac{2.1214 E+01}{2,4709 E+01}$ & $\frac{.4 .3277+02}{4.4280 E+02}$ & \\
\hline $3.8584 \mathrm{E}+01$ & & $\frac{2 ., L 111 E+* 0}{3.1106 E+00}$ & $6.5700 E+01$ & $4.5152 E+01$ & $\frac{4.6412 E+01}{5.3043 E+01}$ & $\frac{2.0112 E+01}{2.9842 E+01}$ & & $4.4252 E+02$ & \\
\hline $3.7041 E+01$ & $3.0058 \mathrm{E} \cdot 01$ & $\frac{3.1 .4094 E+00}{3}$ & $7.3922 E+01$ & $5.0706 E+01$ & $5.0673 \mathrm{E}+01$ & $3.3572 E+01$ & $3.1820 E+01$ & $4.1214 E+02$ & \\
\hline & & & & & & & & & \\
\hline walght trection & weloht rinction & wodght frection & walght Fection & wolght frection & woloht kection & wolght frection & Wologhi trection & watere traction & $\frac{\text { weight ith }}{\text { sig }}$ \\
\hline$\infty$ & & Eri203 & $E-203$ & E1203 & 6203 & ERO3 & Er203 & Total & TOTAL \\
\hline$\frac{0.16}{0.16}$ & 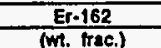 & 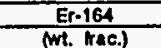 & Er-165 & $\frac{E[-167}{\text { Ent. }}$ & 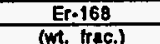 & $\frac{\text { Er.170 }}{\text { mit. The.) }}$ & $\frac{0.16}{\text { m. trac.) }}$ & $\frac{0.18}{(m+1 \text { trec) }}$ & \\
\hline $2.8612 E \cdot 02$ & $0.0000 E+00$ & $0.0000 E+00$ & $0.00000 E+00$ & $0.0000 \mathrm{E}+00$ & $0.0000,00$ & $0.0000 E+00$ & $0.0000 E+00$ & $2.5034 \mathrm{E} .01$ & \\
\hline $2.7534 \mathrm{E} \cdot 02$ & $7.8623 E .05$ & $2.1681 E .04$ & $4.5800 \mathrm{E} \cdot 03$ & $3.1472 E-03$ & $3.6072 E-03$ & $2.0800 E-03$ & $1.0716 \mathrm{E}-03$ & $2.4823 E=01$ & $\frac{1.00}{1.02}$ \\
\hline $2.6473 \mathrm{E} \cdot 02$ & $3.6965 E-05$ & $4.3035 E-04$ & $\frac{0.0909 E \cdot 03}{0.02010 .32}$ & $6.2460 \mathrm{E} \cdot 03$ & $7.3385=0.03$ & $\begin{array}{ll}0.12878 .03 \\
\end{array}$ & 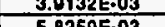 & $2.4615 E=01$ & 0000 \\
\hline$\frac{2.5428 E=02}{2,4398 E=02}$ & $\begin{array}{l}5.5032 .05 \\
7032505\end{array}$ & 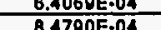 & $\begin{array}{l}1.3534 f_{0}=02 \\
170.02\end{array}$ & 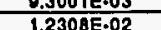 & $\frac{1.002506}{1,450.02}$ & $\frac{0.00}{8,136 E-03}$ & $\begin{array}{r}-5.8250 E \cdot 03 \\
.7101 E \cdot 03\end{array}$ & $\frac{2.4000=01}{21070.019}$ & $\frac{1.00}{100}$ \\
\hline$\frac{2.4338 E E .02}{23383 E-02}$ & 1.283ite.0s & $\frac{8.02005-04}{1.0521 \mathrm{E}-03}$ & $\frac{1.0110 .02}{2.2224 E \cdot 02}$ & $\frac{1.5000606}{1.5271 E .02}$ & $\frac{1.7010 E .02}{1.02}$ & $1.0003 \mathrm{E}=02$ & $\begin{array}{c}.6665 E .03 \\
0.5656\end{array}$ & $\frac{2.4076=01}{32005.01}$ & \\
\hline$\frac{2.2383 E-02}{2.23}$ & $1.0765 E \cdot 04$ & $1.2532 E \cdot 03$ & $2.6473 E .02$ & $1.8101 E .02$ & $2.1370 \mathrm{E} .02$ & $1.2023 \mathrm{E}-02$ & $1.1306 E .02$ & 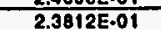 & \\
\hline $2.1398 \mathrm{E} .02$ & $1.2467 \mathrm{E} \cdot 04$ & $1.4514 E_{0}-03$ & $3.0661 \ldots \cdot 02$ & $2.1060 E=02$ & $2,4751 E \div 02$ & $1.3025 E-02$ & $1.3108 E=02$ & $2.3610 E-01$ & \\
\hline $\begin{array}{l}2.0427 E .02 \\
1.010770 .02\end{array}$ & $-1.4145 E \cdot 04$ & $\begin{array}{l}1.6468 E=03 \\
1304 E_{0}=03\end{array}$ & $\frac{3.6788 E .02}{3.8856 E .02}$ & $\begin{array}{l}2.3005 E \cdot 02 \\
26700=02\end{array}$ & 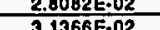 & $\frac{1.670 .02}{1,7076.02}$ & $\frac{1.4075 E=02}{1.6726 .02}$ & $2.3428 E-01$ & \\
\hline & 1.58000 =04 & 1.030090003 & & & & & $8,67265: 02$ & & \\
\hline & & & & & & & & & \\
\hline & & & & & & & & & \\
\hline & & & & & & & & & \\
\hline & & & & & & & & & \\
\hline & & & & & & & & & \\
\hline & & & & & & & & & \\
\hline & & & & & & & & & \\
\hline & & & & & & & & & \\
\hline & & & & & & & & & \\
\hline & & & & & & & & & \\
\hline & & & & & & & & & \\
\hline & & & & & & & & & \\
\hline & & & & & & & & & 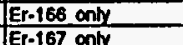 \\
\hline & & & MCNP.traction & MCNP.frection & & & & MCNP. fraction & $\frac{\sin }{\mathbf{s M}}$ \\
\hline & & & $\frac{E-203}{50603}$ & E[203 & & & 5203 & Total & Toral \\
\hline$\frac{0.18}{(\mathrm{a} / \mathrm{b} / \mathrm{cm})}$ & & & $\frac{E \mathrm{r} \cdot 166}{(\mathrm{c} / \mathrm{b} / \mathrm{cm})}$ & $(\mathrm{d} / \mathrm{b} / \mathrm{cm})$ & & & $\frac{0.18}{(1 / 10 / \mathrm{cm})}$ & $\frac{0.16}{0.10 / \mathrm{cm})}$ & $\begin{array}{c}\text { Aloms } \\
(\mathrm{e} b / \mathrm{cm}) \\
\end{array}$ \\
\hline & & & $\frac{0.0000 E+00}{1.1465 .003}$ & $\frac{0.0000 E+00}{8.0172 E-04}$ & & & & $\frac{0.6220 E .01}{0.43050 .01}$ & $\frac{1.0000 E+00}{1.0000 E+00}$ \\
\hline & & & 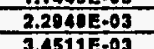 & $\frac{1.56752 .03}{2.3572 .03}$ & & & & \begin{tabular}{|c|}
$0.4 A 40 E .01$ \\
$.05532 E .01$ \\
\end{tabular} & \begin{tabular}{|c|}
$.0000 E+00$ \\
$1.0000 E+00$
\end{tabular} \\
\hline
\end{tabular}




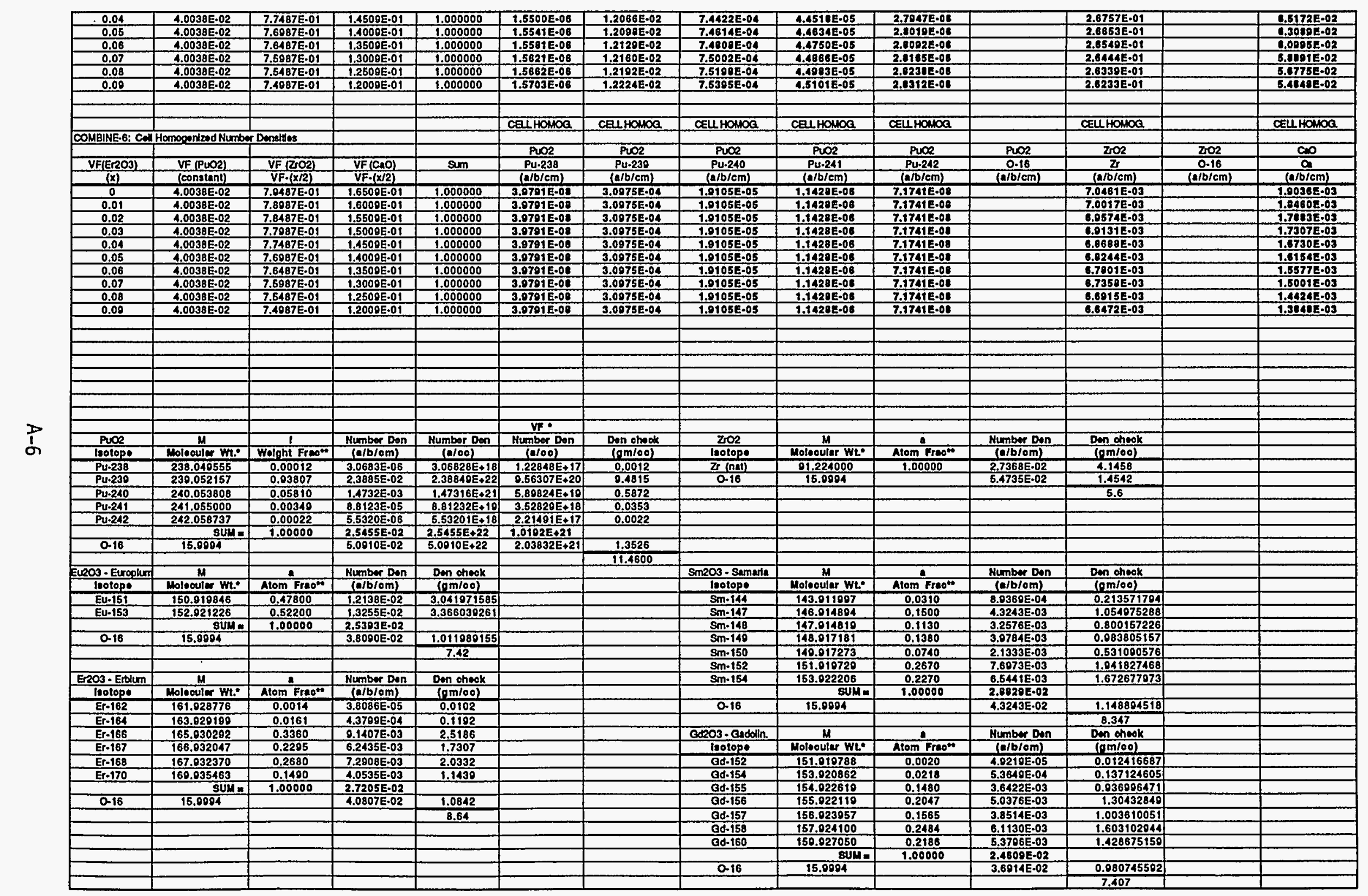




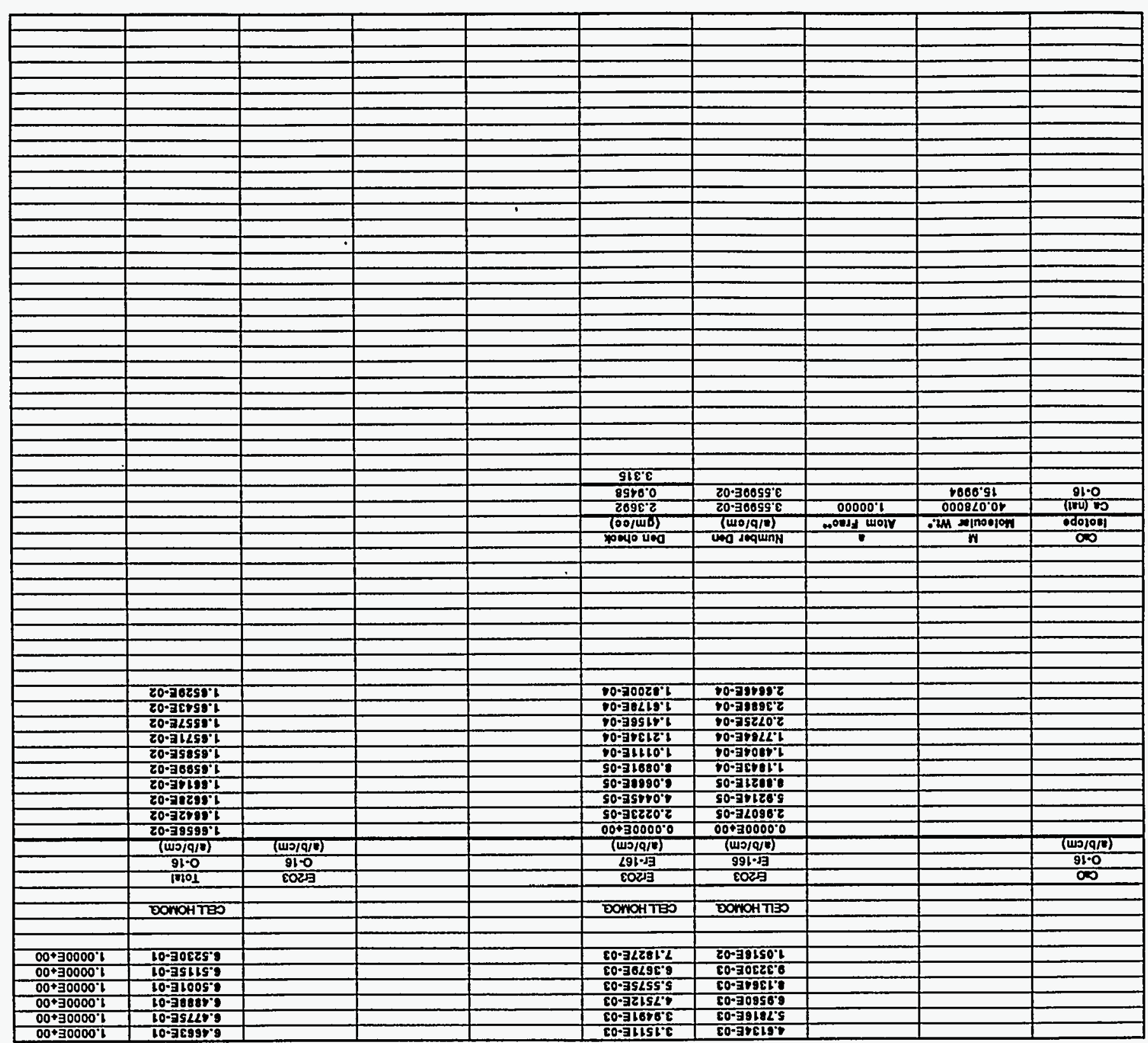


APPENDIX B

NEUTRON CROSS SECTION DEVELOPMENT

B-1 


\section{APPENDIX B}

MCNP neutron cross section libraries were developed for the following isotopes at the given temperature:

\begin{tabular}{|c|c|c|}
\hline Element & Isotope & $\begin{array}{c}\text { Temperature } \\
(\mathrm{K})\end{array}$ \\
\hline \multirow[t]{6}{*}{ Erbium } & ${ }^{166} \mathrm{Er},{ }^{167} \mathrm{Er}$ & 293 \\
\hline & $166 \mathrm{Er},{ }^{167} \mathrm{Er}$ & 587 \\
\hline & $166 \mathrm{Er}, 167 \mathrm{Er}$ & 880 \\
\hline & $166 \mathrm{Er}, 167 \mathrm{Er}$ & 1174 \\
\hline & $166 \overrightarrow{\mathrm{Er}}, 167 \overrightarrow{\mathrm{Er}}$ & 1762 \\
\hline & ${ }^{166} \mathrm{Er},{ }^{167} \mathrm{Er}$ & 2153 \\
\hline \multirow[t]{6}{*}{ Europium } & ${ }^{151} \mathrm{Eu},{ }^{152} \mathrm{Eu},{ }^{153} \mathrm{Eu},{ }^{154} \mathrm{Eu}$ & 293 \\
\hline & ${ }^{151} \mathrm{Eu},{ }^{152} \mathrm{Eu},{ }^{153} \mathrm{Eu},{ }^{154} \mathrm{Eu}$ & 587 \\
\hline & ${ }^{151} \mathrm{Eu},{ }^{152} \mathrm{Eu},{ }^{153} \mathrm{Eu},{ }^{154} \mathrm{Eu}$ & 880 \\
\hline & ${ }^{151 \mathrm{Eu}},{ }^{152} \mathrm{Eu},{ }^{153} \mathrm{Eu},{ }^{154} \mathrm{Eu}$ & 1174 \\
\hline & ${ }^{151} \mathrm{Eu},{ }^{152} \mathrm{Eu},{ }^{153} \mathrm{Eu},{ }^{154} \mathrm{Eu}$ & 1762 \\
\hline & ${ }^{151} \mathrm{Eu},{ }^{152} \mathrm{Eu},{ }^{153} \mathrm{Eu},{ }^{154} \mathrm{Eu}$ & 2153 \\
\hline \multirow[t]{6}{*}{ Gadolinium } & ${ }^{152} \mathrm{Gd},{ }^{154} \mathrm{Gd},{ }^{155} \mathrm{Gd},{ }^{156} \mathrm{Gd},{ }^{157} \mathrm{Gd},{ }^{158} \mathrm{Gd},{ }^{160} \mathrm{Gd}$ & 293 \\
\hline & ${ }^{152} \mathrm{Gd},{ }^{154} \mathrm{Gd},{ }^{155} \mathrm{Gd}, 156 \mathrm{Gd},{ }^{157} \mathrm{Gd},{ }^{158} \mathrm{Gd},{ }^{160} \mathrm{Gd}$ & 587 \\
\hline & ${ }^{152} \mathrm{Gd},{ }^{154} \mathrm{Gd}, 155 \mathrm{Gd}, 156 \mathrm{Gd}, 157 \mathrm{Gd}, 158 \mathrm{Gd}, 160 \mathrm{Gd}$ & 880 \\
\hline & ${ }^{152} \mathrm{Gd},{ }^{154} \mathrm{Gd}, 155 \mathrm{Gd}, 156 \mathrm{Gd}, 157 \mathrm{Gd}, 158 \mathrm{Gd}, 160 \mathrm{Gd}$ & 1174 \\
\hline & $152 \mathrm{Gd},{ }^{154} \mathrm{Gd}, 155 \mathrm{Gd}, 156 \mathrm{Gd}, 157 \mathrm{Gd}, 158 \mathrm{Gd}, 160 \mathrm{Gd}$ & 1762 \\
\hline & ${ }^{152} \mathrm{Gd},{ }^{154} \mathrm{Gd},{ }^{155} \mathrm{Gd}, 156 \mathrm{Gd},{ }^{157} \mathrm{Gd}, 158 \mathrm{Gd},{ }^{160} \mathrm{Gd}$ & 2153 \\
\hline \multirow[t]{4}{*}{ Hafnium } & ${ }^{174} \mathrm{Hf},{ }^{176} \mathrm{Hf},{ }^{177} \mathrm{Hf},{ }^{178} \mathrm{Hf},{ }^{179} \mathrm{Hf},{ }^{180} \mathrm{Hf}$ & 293 \\
\hline & ${ }^{174} \mathrm{Hf},{ }^{176} \mathrm{Hf},{ }^{177} \mathrm{Hf},{ }^{178} \mathrm{Hf},{ }^{179} \mathrm{Hf},{ }^{180} \mathrm{Hf}$ & 587 \\
\hline & ${ }^{174} \mathrm{Hf}, 176 \mathrm{Hf},{ }^{177} \mathrm{Hf},{ }^{178} \mathrm{Hf},{ }^{179} \mathrm{Hf}, 180 \mathrm{Hf}$ & 880 \\
\hline & ${ }^{174} \mathrm{Hf},{ }^{176} \mathrm{Hf},{ }^{177} \mathrm{Hf},{ }^{178} \mathrm{Hf},{ }^{179} \mathrm{Hf}, 180 \mathrm{Hf}$ & 1174 \\
\hline \multirow[t]{5}{*}{ Plutonium } & ${ }^{239} \mathrm{Pu},{ }^{240} \mathrm{Pu},{ }^{241} \mathrm{Pu},{ }^{242} \mathrm{Pu}$ & 587 \\
\hline & ${ }^{239} \mathrm{Pu},{ }^{240 \mathrm{Pu}},{ }^{241} \mathrm{Pu}, 242 \mathrm{Pu}$ & 880 \\
\hline & ${ }^{239} \mathrm{Pu},{ }^{240} \mathrm{Pu},{ }^{241} \mathrm{Pu}, 242 \mathrm{Pu}$ & 1174 \\
\hline & ${ }^{239} \mathrm{Pu},{ }^{240} \mathrm{Pu},{ }^{241} \mathrm{Pu}, 242 \mathrm{Pu}$ & 1762 \\
\hline & ${ }^{239} \mathrm{Pu},{ }^{240} \mathrm{Pu},{ }^{241} \mathrm{Pu}, 242 \mathrm{Pu}$ & 2153 \\
\hline
\end{tabular}




\section{APPENDIX B}

\begin{tabular}{|c|c|c|}
\hline Element & Isotope & $\begin{array}{c}\text { Temperature } \\
\text { (K) }\end{array}$ \\
\hline Zirconium & 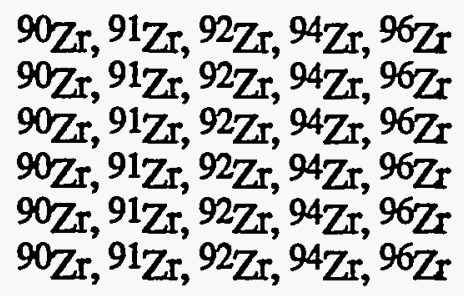 & $\begin{array}{r}293 \\
587 \\
880 \\
1174 \\
1762 \\
2153\end{array}$ \\
\hline
\end{tabular}

Samarium ${ }^{144} \mathrm{Sm},{ }^{147} \mathrm{Sm},{ }^{148} \mathrm{Sm},{ }^{149} \mathrm{Sm},{ }^{150} \mathrm{Sm},{ }^{152} \mathrm{Sm},{ }^{154} \mathrm{Sm} \quad 2153$

B-3 


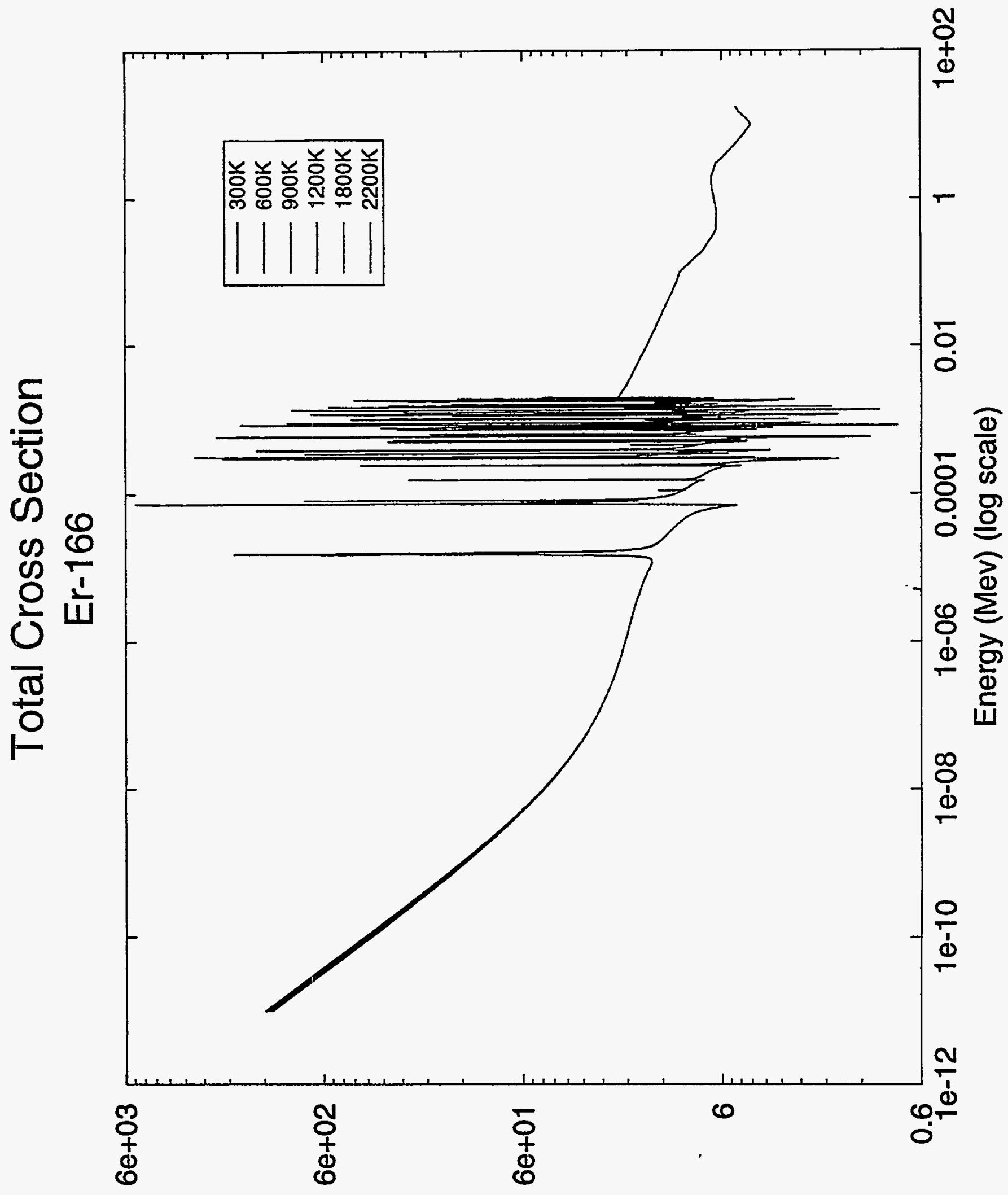

(q) Uo!̣ors ssojo 


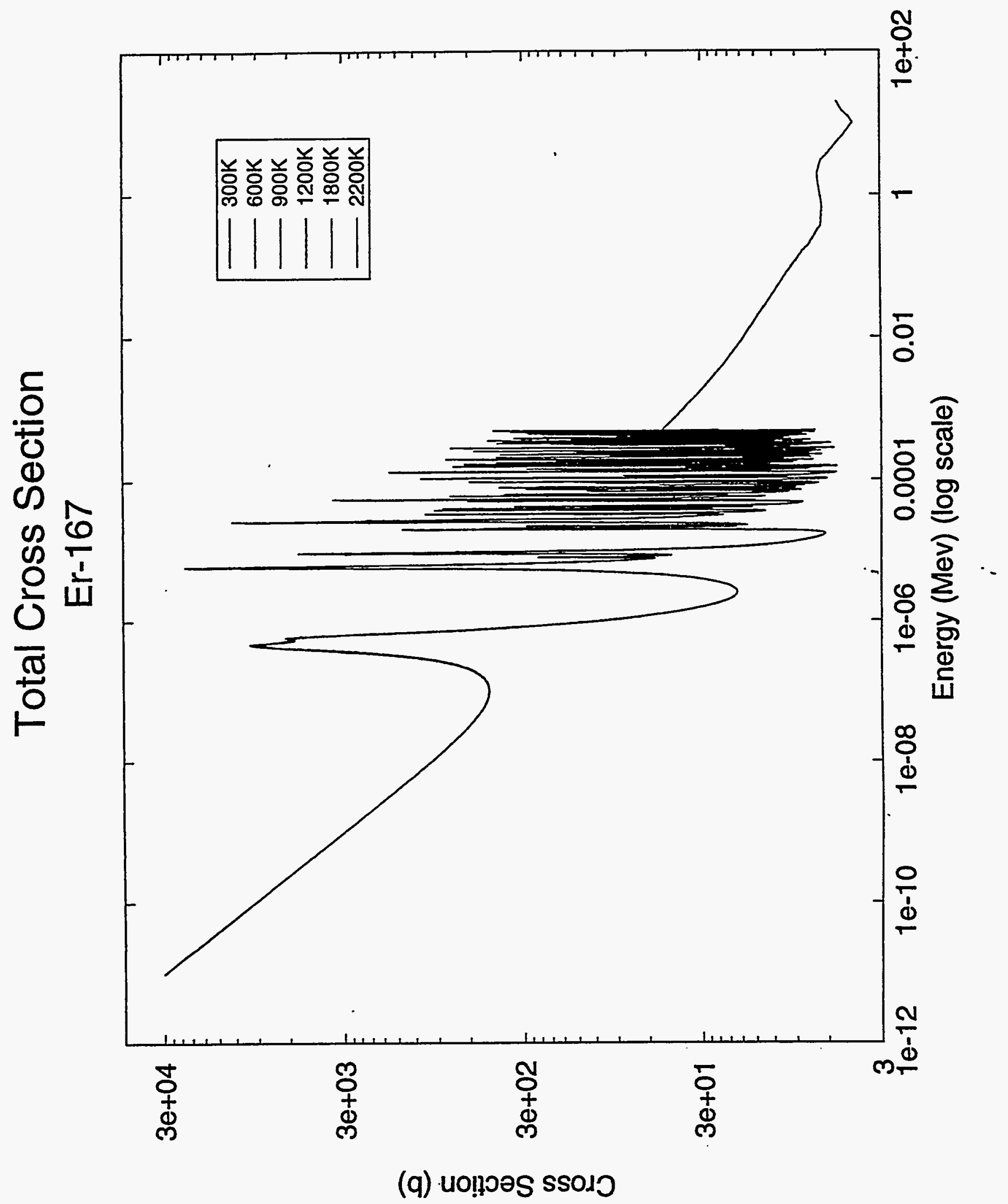

B-5 


\section{Total Absorption Cross Section \\ Pu-239}

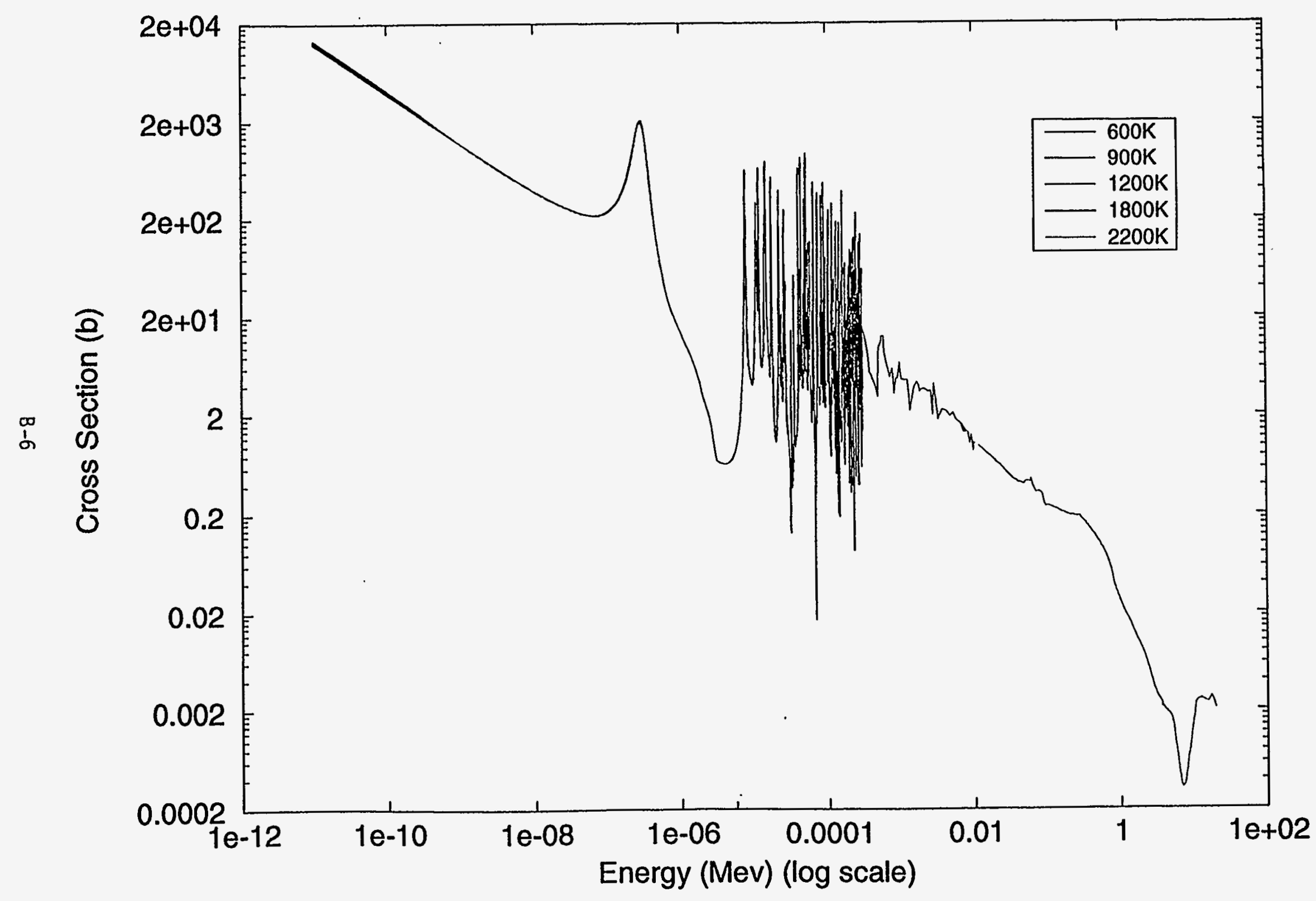




\section{Total Absorption Cross Section}

Pu-240

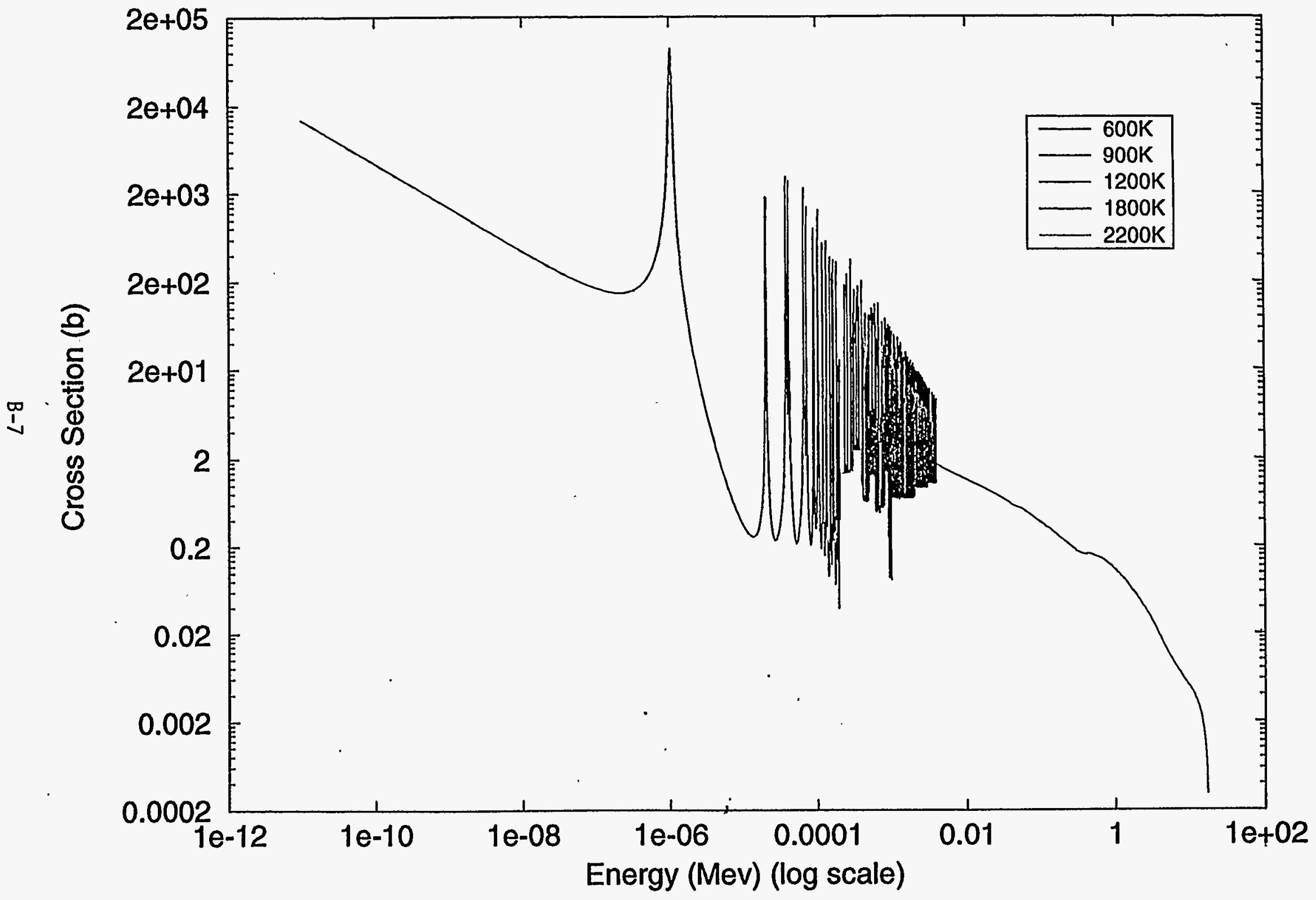




\section{Total Absorption Cross Section \\ Pu-241}

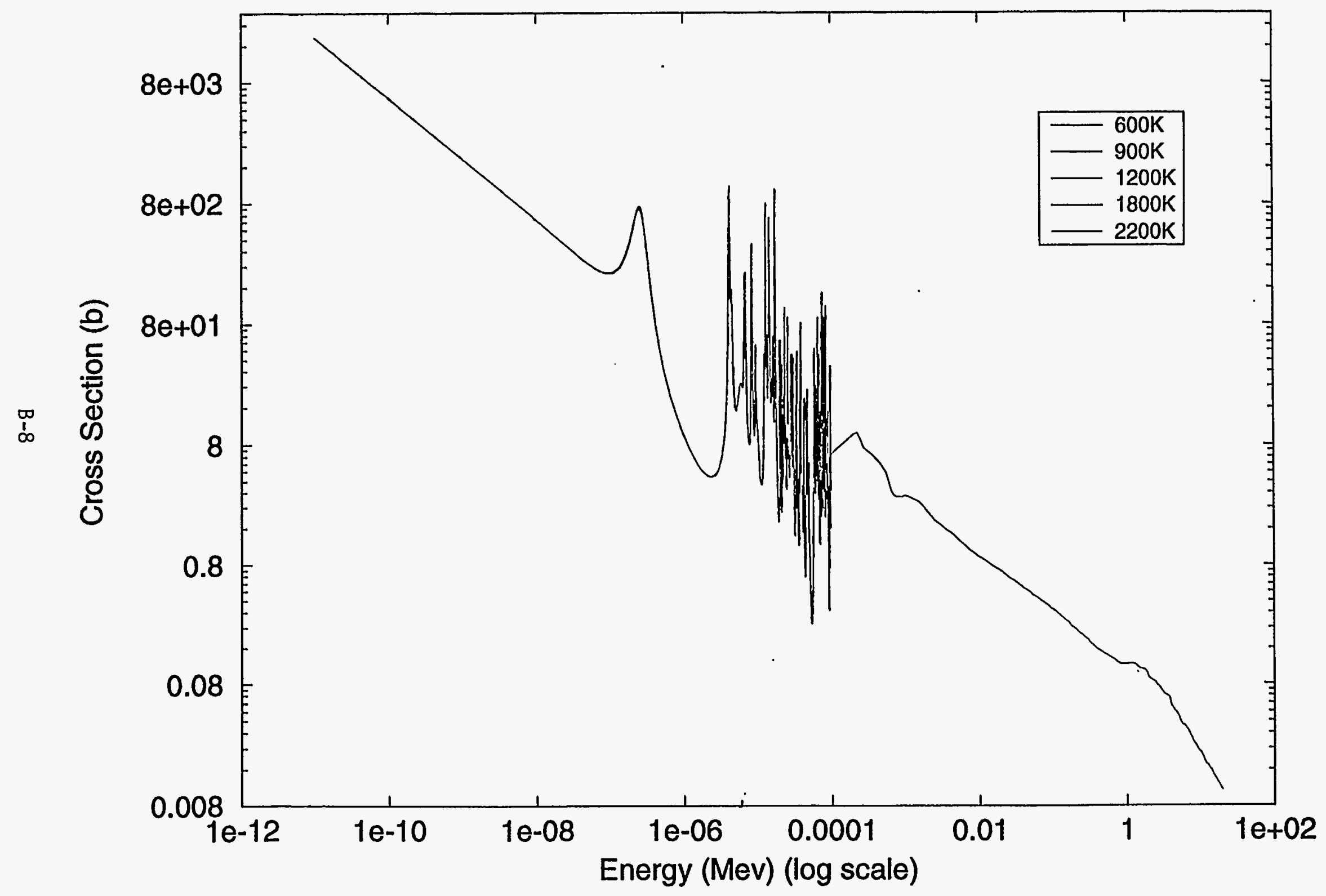




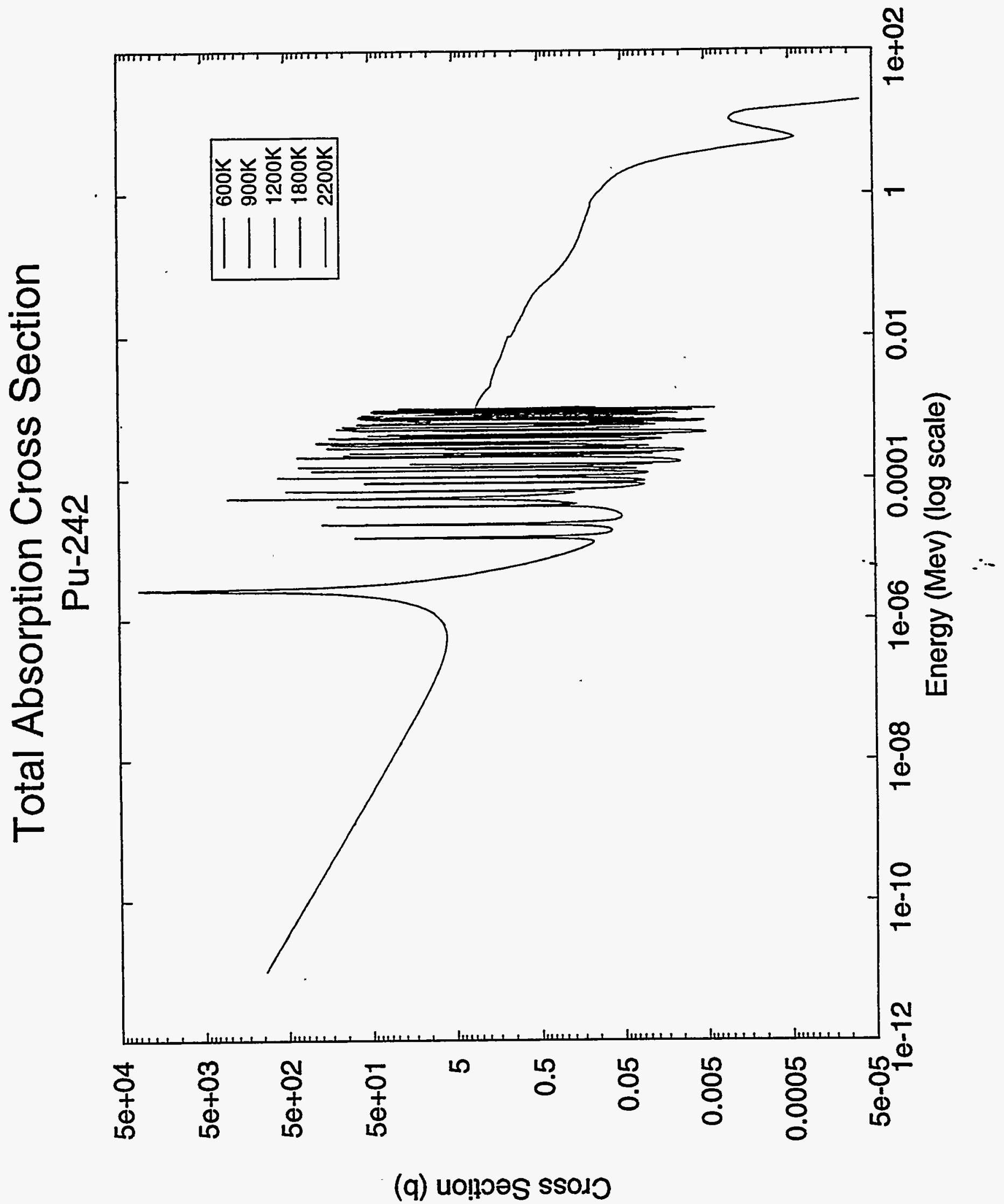




\section{Total Cross Section}

\section{Pu-239}

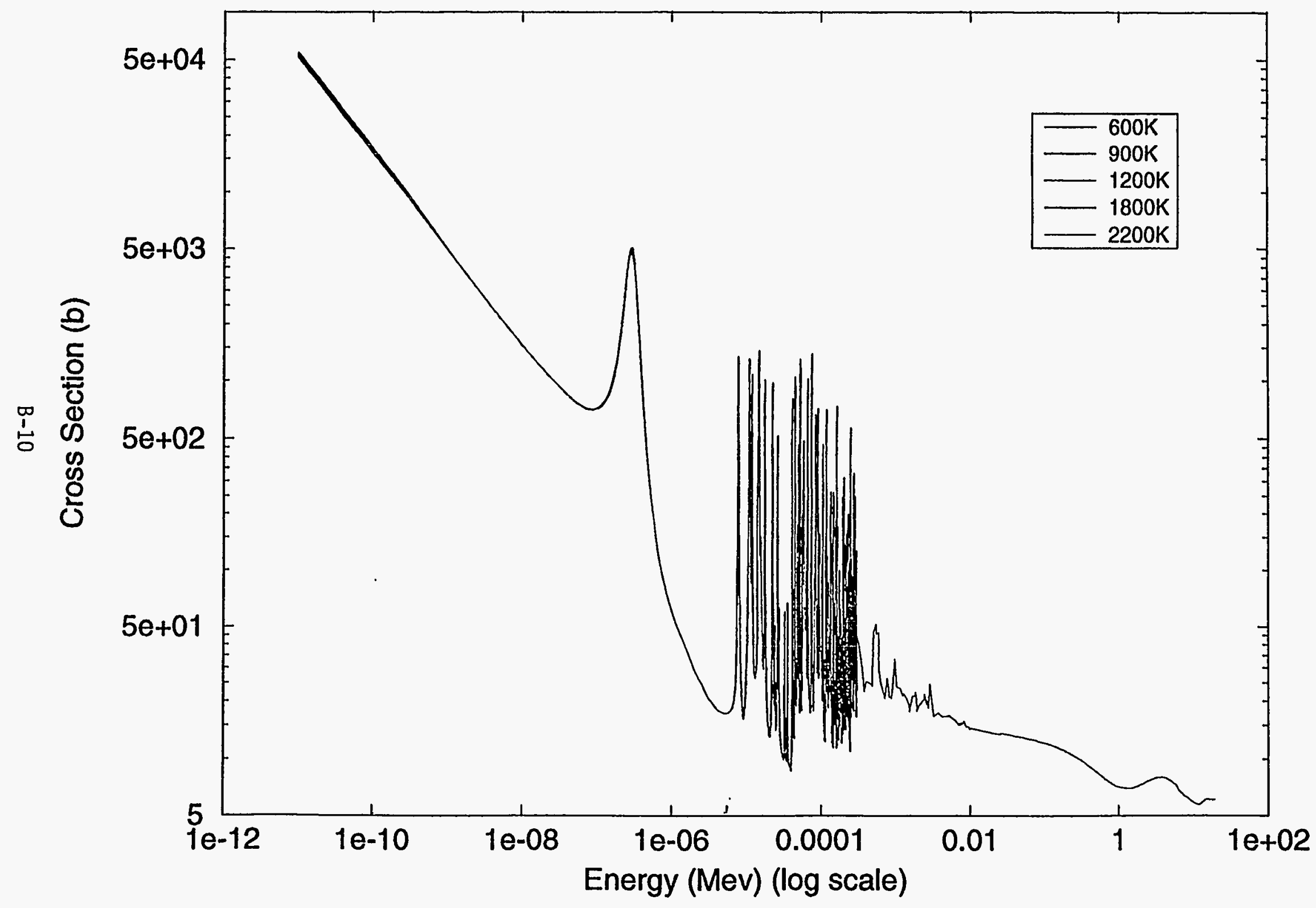




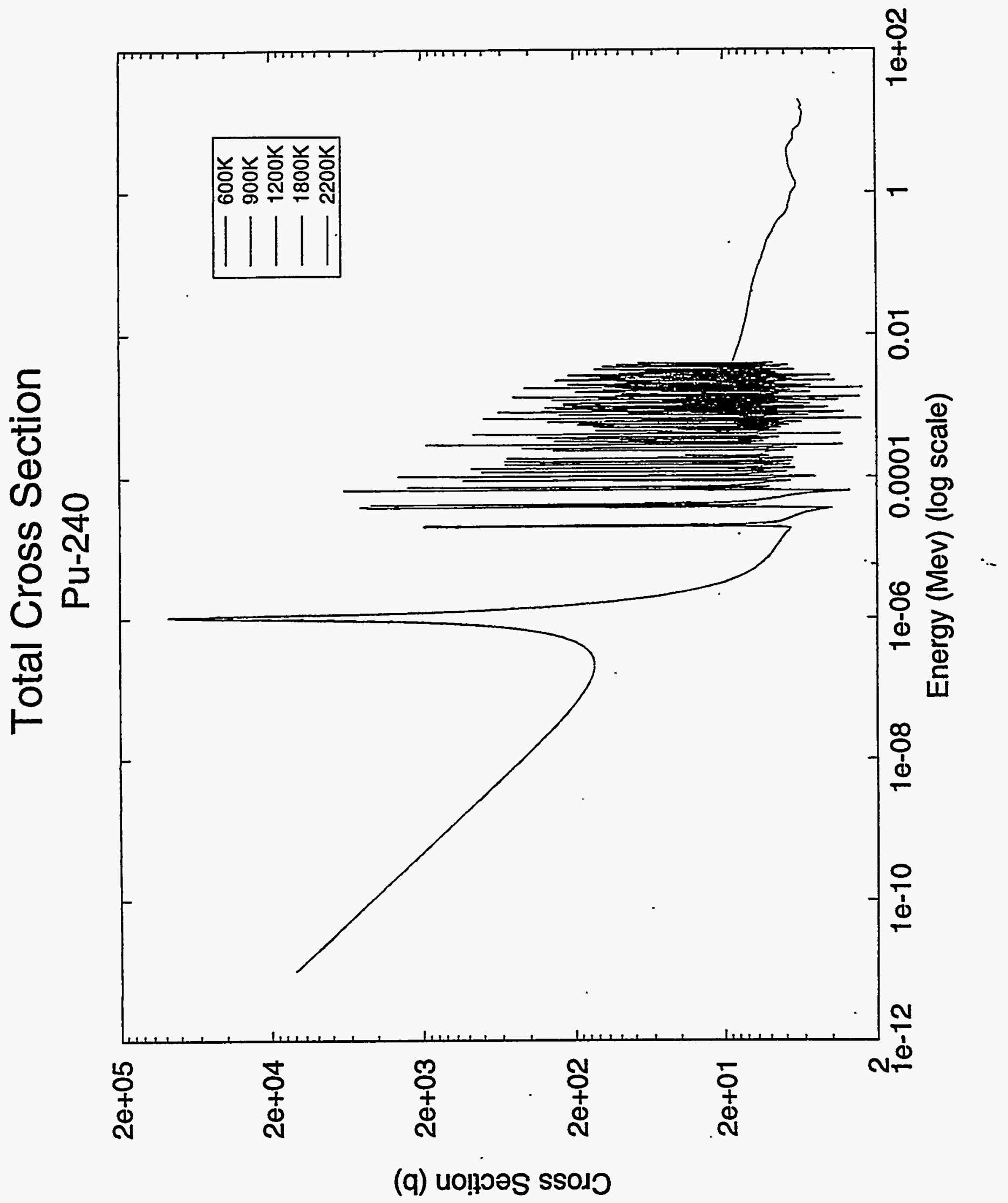

B-11 


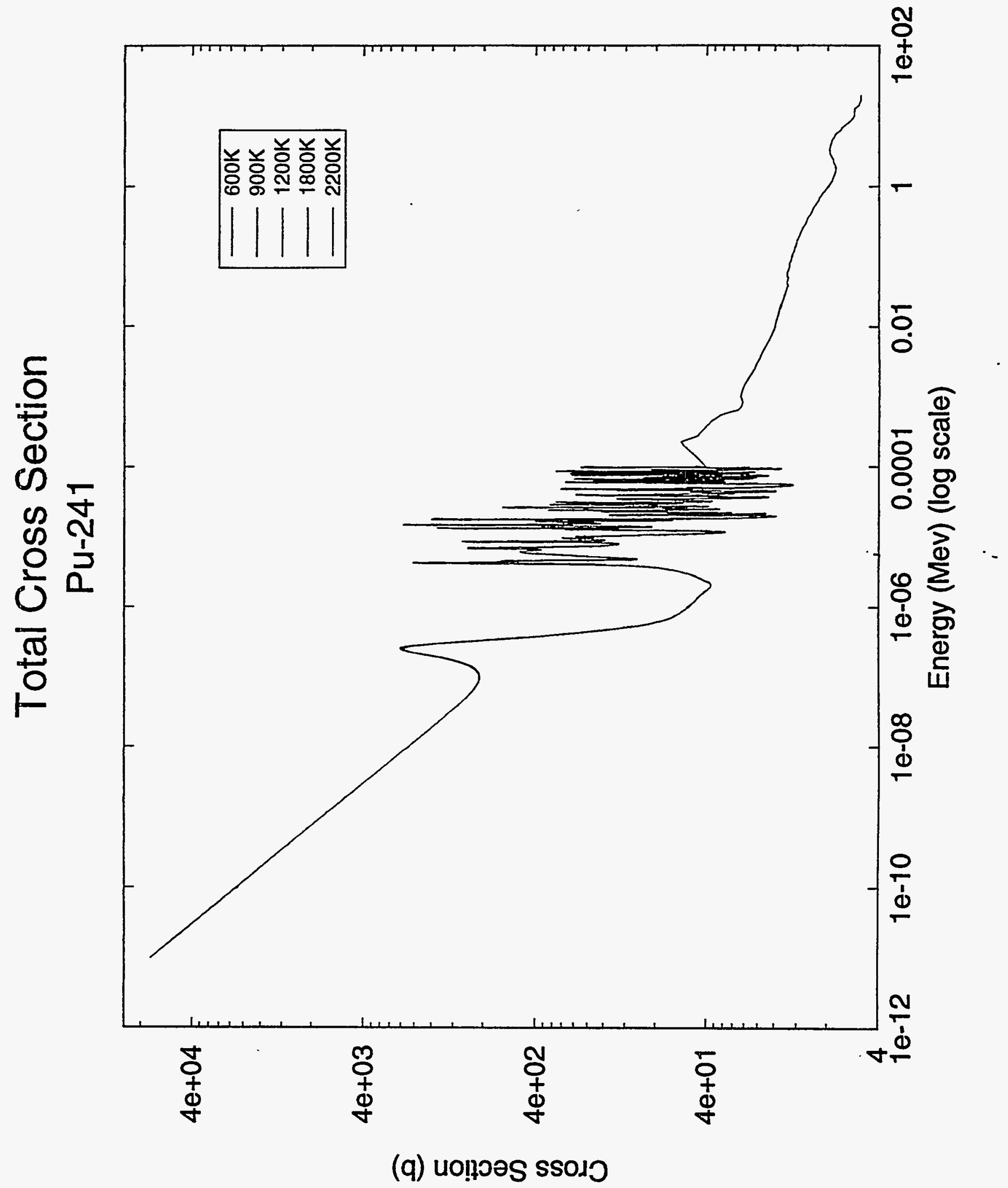




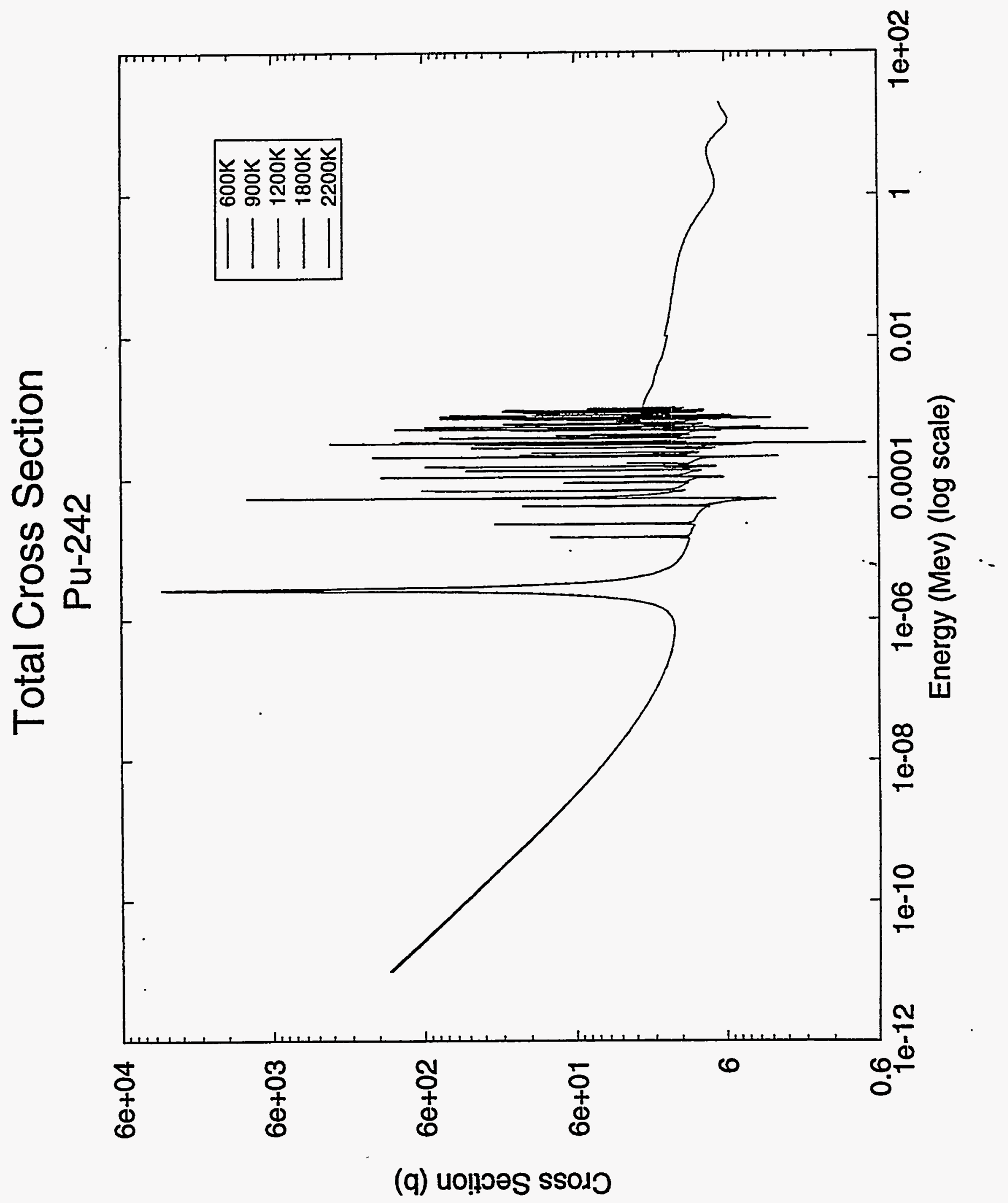

B-13 


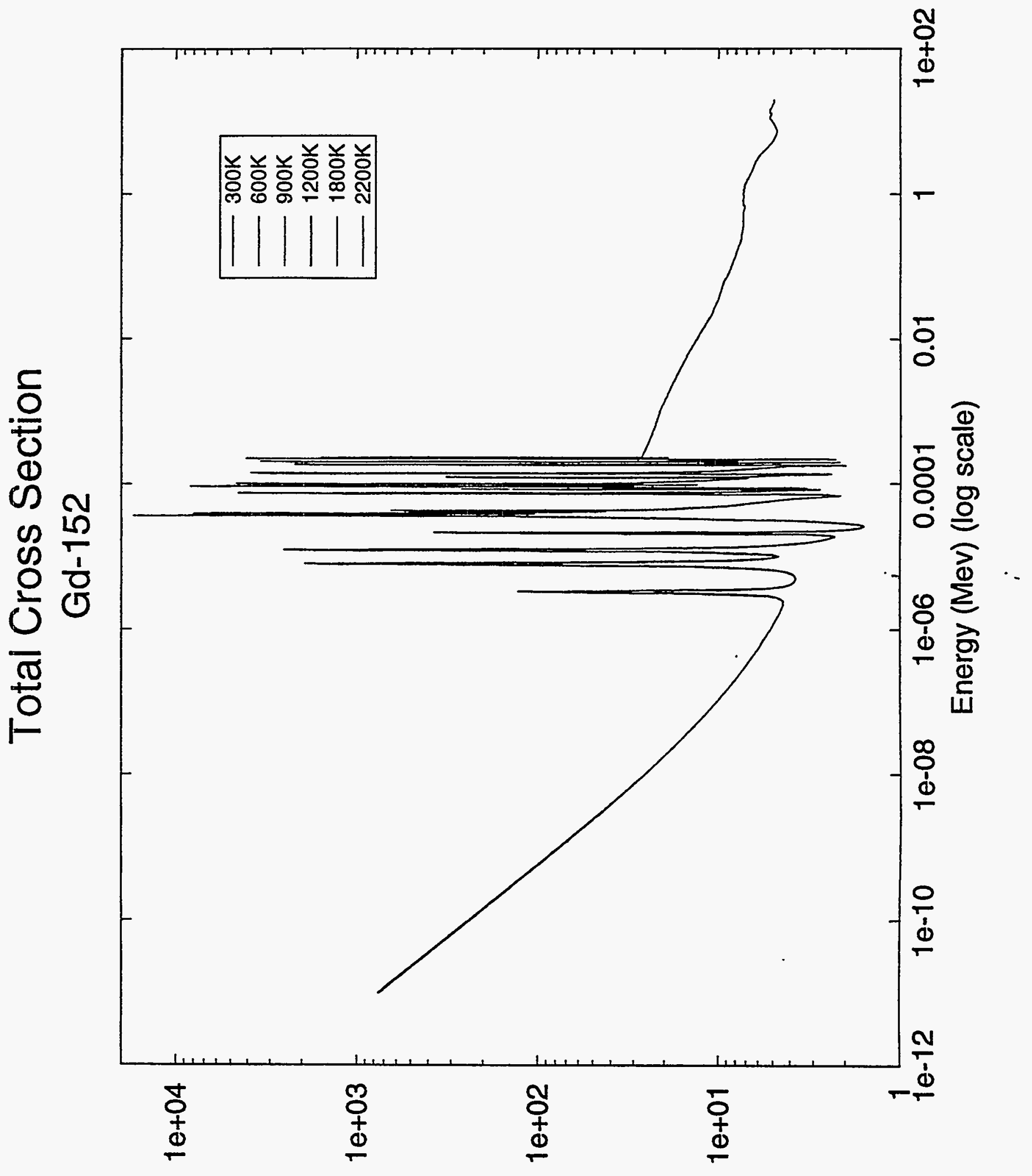

(q) uo!noos ssojo 


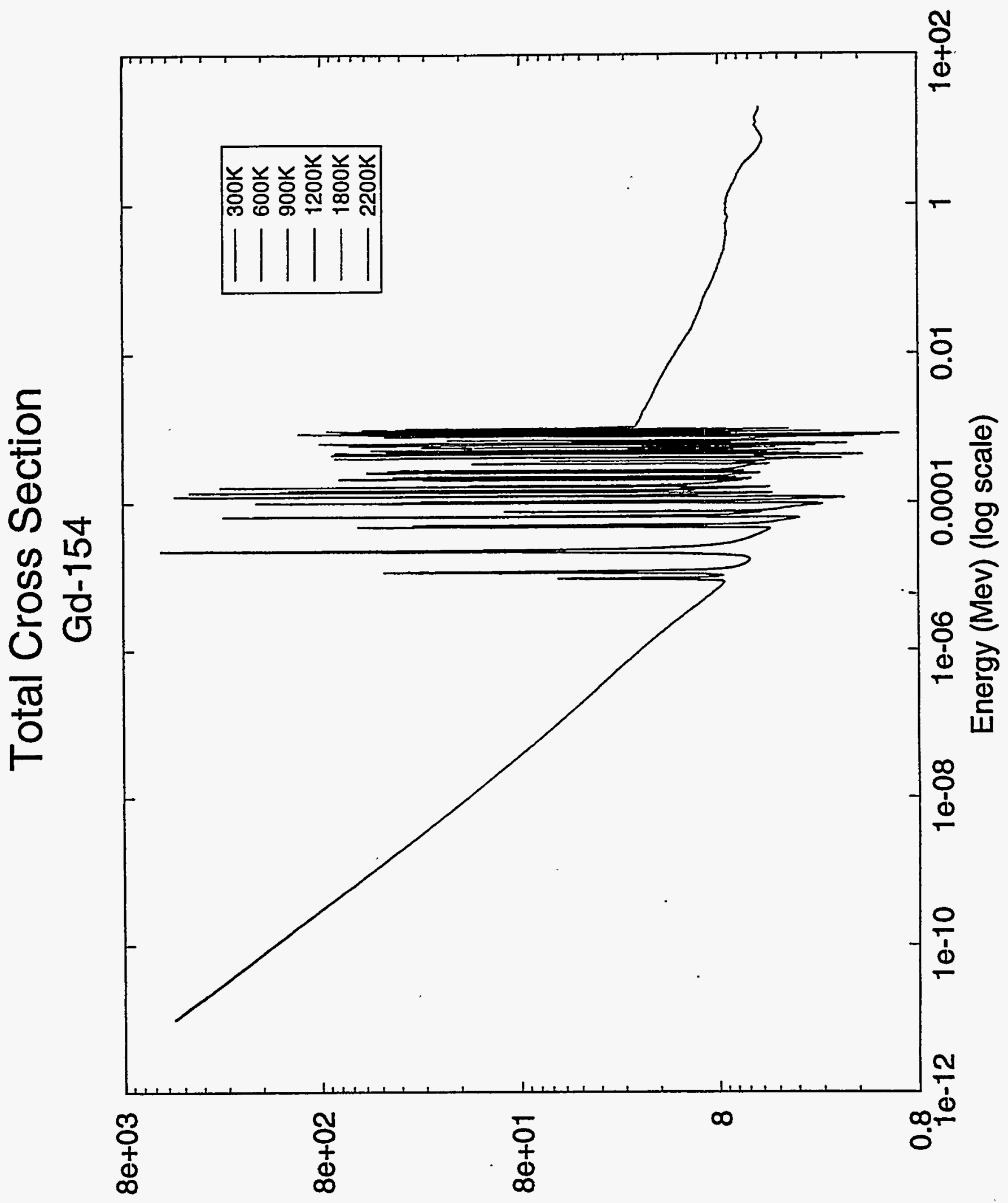

(q) uo!̣ڤos ssodo

B-15 


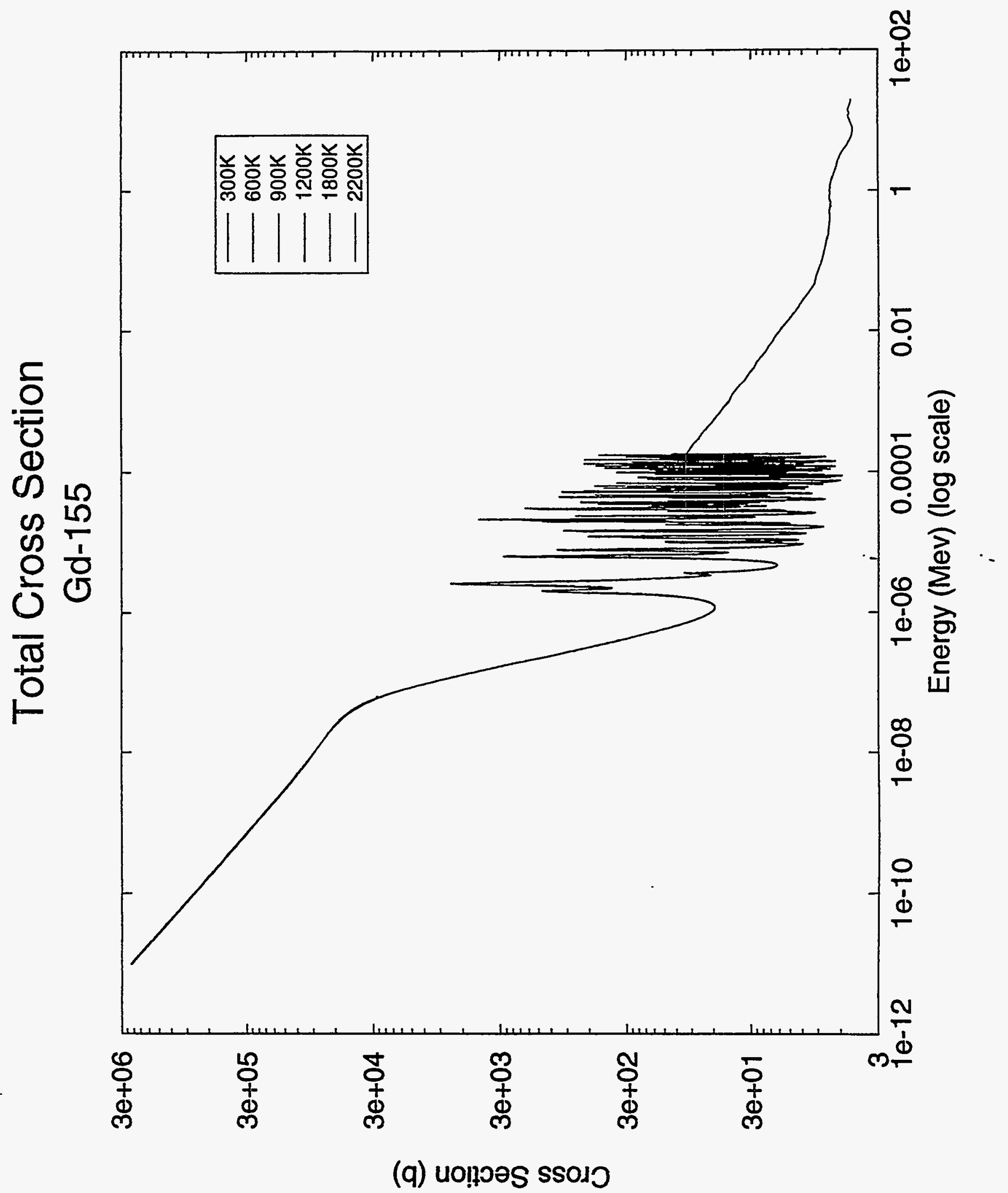




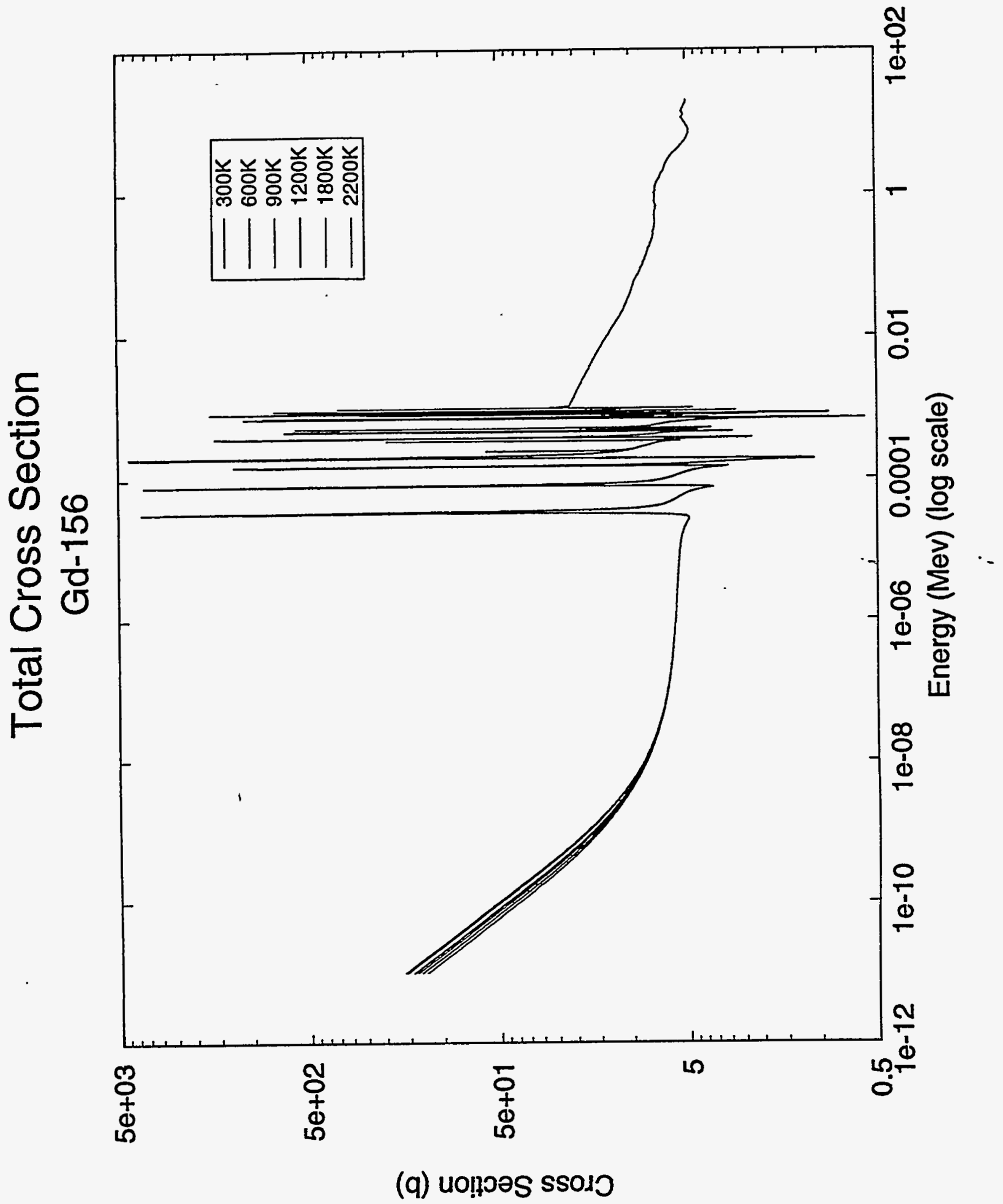

B-17 


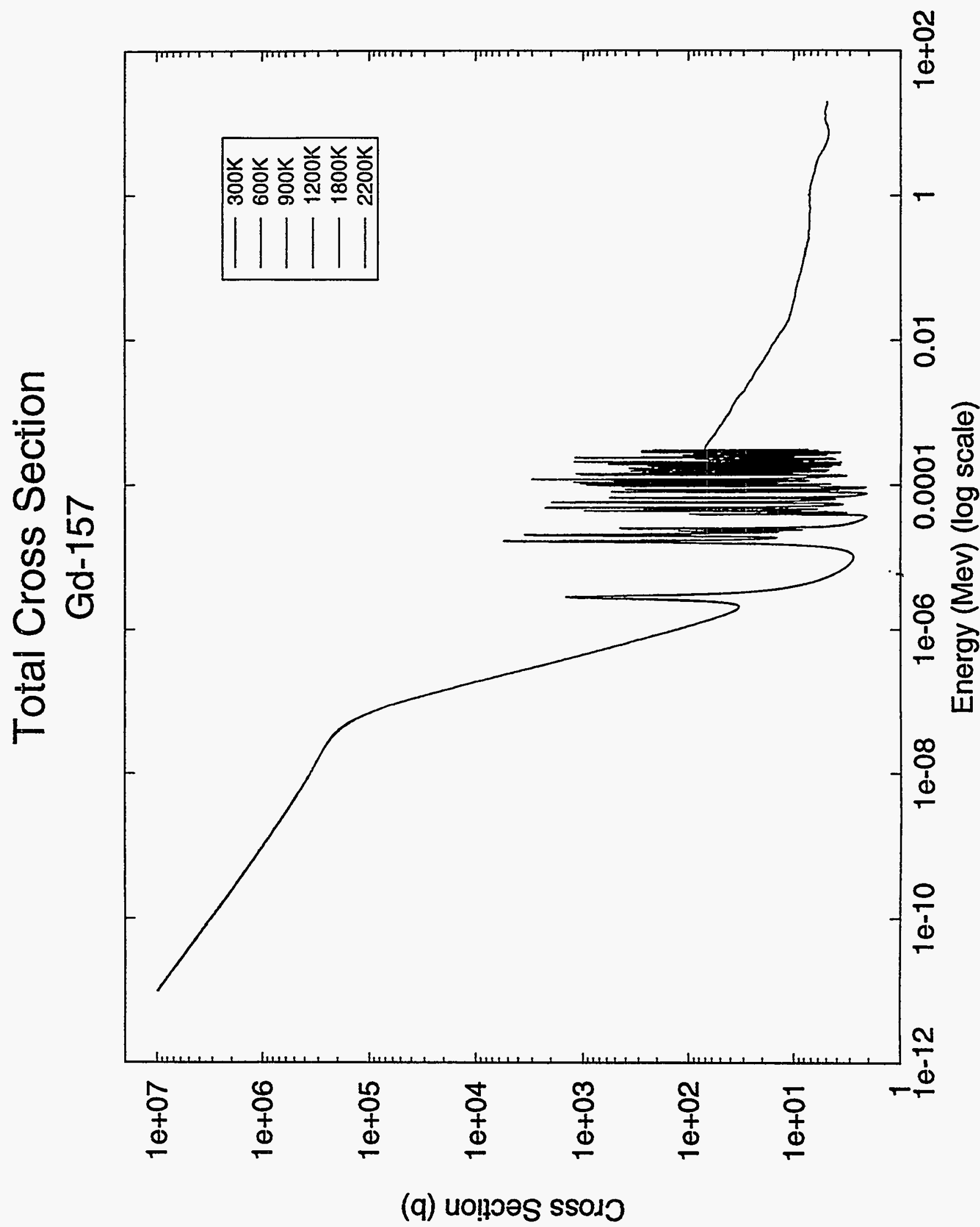


Total Cross Section

Gd-158

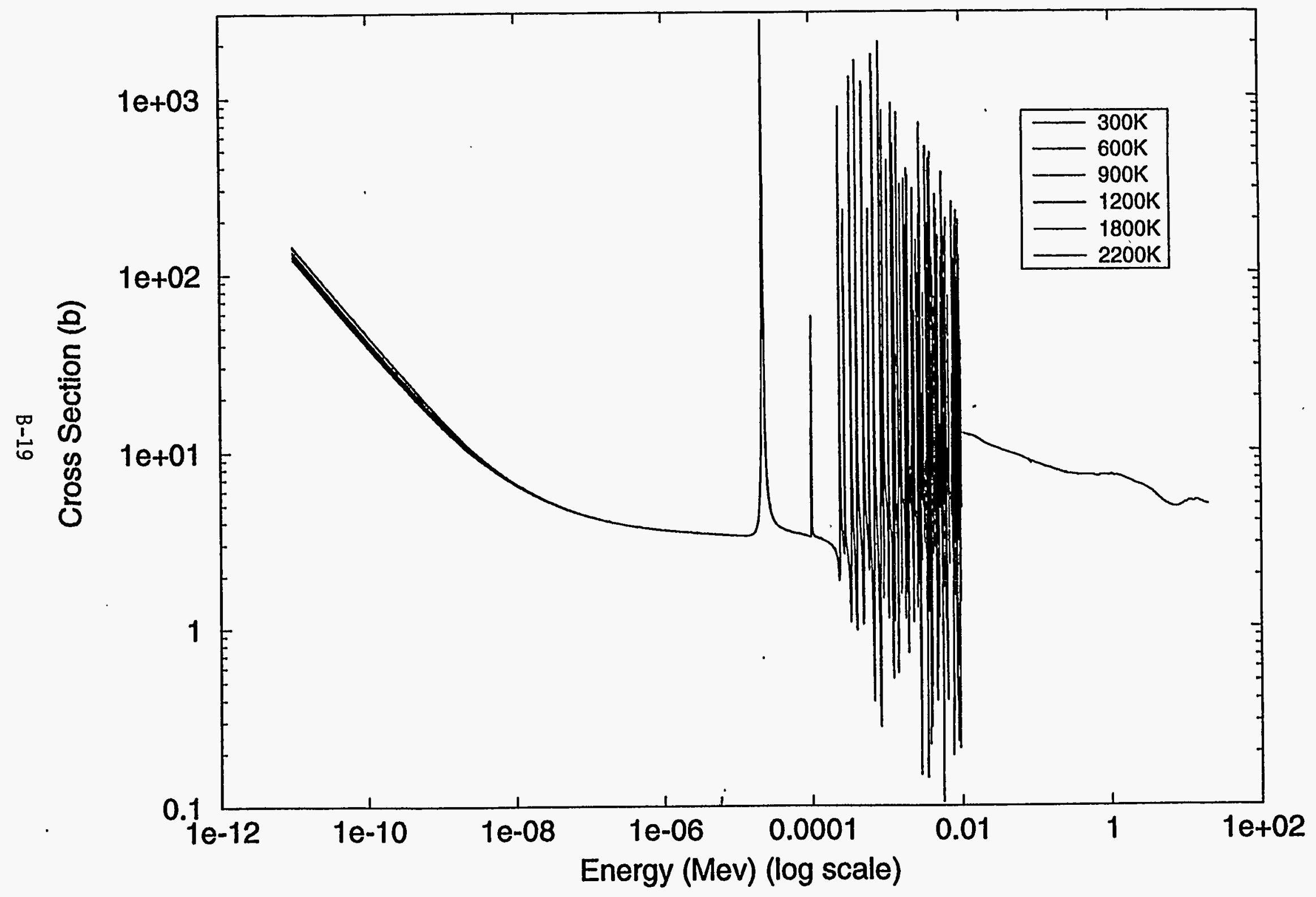




\section{Total Cross Section}

Gd-160

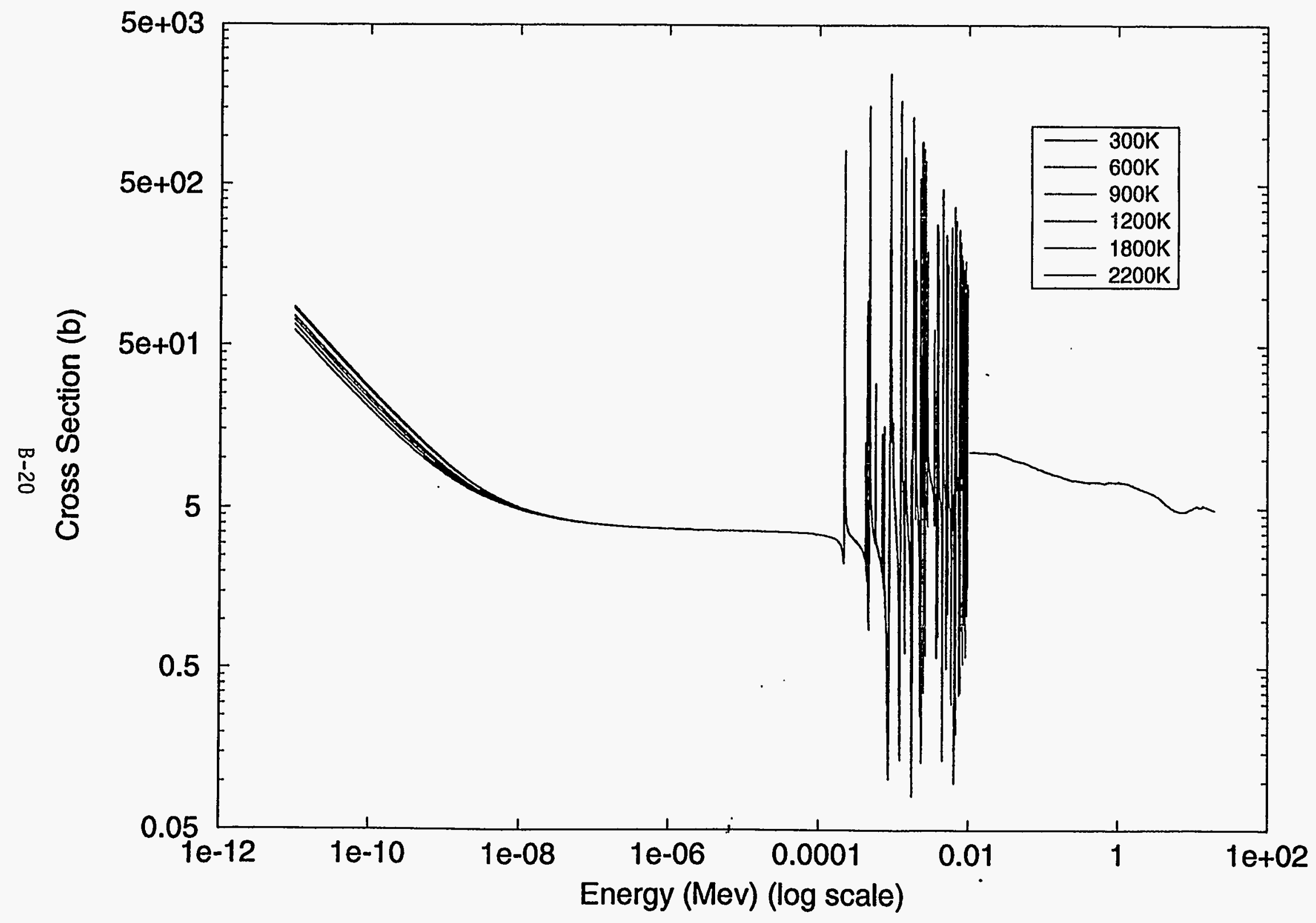




\section{APPENDIX C}

\section{MODERATOR/COOLANT ATOMIC NUMBER DENSITIES}

AT

\section{SATURATION CONDITIONS}

C-1 


\begin{tabular}{|c|c|c|c|c|c|c|}
\hline WATER & \multicolumn{3}{|c|}{ Liquid at Salurated Pressure and Temperature } & & & \\
\hline & \multicolumn{3}{|c|}{ ABWR Vessel Core Pressure $=73.7(\mathrm{~kg} / \mathrm{cm} 2 \mathrm{~g})$} & 1050 & psig & \\
\hline & \multicolumn{3}{|c|}{ Corresponding Saturated Temperature= } & 550.71 & $F$ & \\
\hline & \multicolumn{3}{|c|}{ Corresponding Saturated Liquid Density= } & 0.02177 & th3 per $\mathrm{b}$ & \\
\hline & \multicolumn{3}{|c|}{ Corresponding Saturated Specific Density $=$} & 0.7358 & $g / c c$ & \\
\hline \multirow{3}{*}{ Density $=$} & & & & & & \\
\hline & 0.73581685 & $g / c c$ & & & & COMBINE-6 \\
\hline & & & & & & CELL-AVE \\
\hline $\mathrm{H} 2 \mathrm{O}$ & $M$ & Vold Frac & Luquid Density & Number Den & MONP & Number Dan \\
\hline Isotope & Molecular Wt." & $(\%)$ & $(g / c c)$ & $(\mathrm{a} / \mathrm{b} / \mathrm{cm})$ & Fraction & $(\mathrm{a} / \mathrm{b} / \mathrm{cm})$ \\
\hline $\mathrm{H}$ & 1.007900 & 0 & 0.7358 & 4.9193E-02 & 6.6667E-01 & $2.7188 E-02$ \\
\hline \multirow[t]{3}{*}{0} & 15.999400 & & & 2.4596E-02 & 3.3333E-01 & $1.3594 \mathrm{E}-02$ \\
\hline & & & & 7.3789E-02 & 1.00000000 & 4.0781 E.02 \\
\hline & & & & & & $4.0781 \mathrm{E}-02$ \\
\hline $\bar{H}$ & 1.007900 & 10 & 0.6622 & 4.4274E-02 & $6.6667 E-01$ & $2.4469 E-02$ \\
\hline \multirow[t]{3}{*}{ O } & 15.999400 & & & 2.2137E-02 & 3.3333E-01 & 1.2234E-02 \\
\hline & & & & $6.6410 \mathrm{E}-02$ & 1.00000000 & 3.6703E-02 \\
\hline & & & & & & 3.6703E-02 \\
\hline $\mathrm{H}$ & 1.007900 & 20 & 0.5887 & 3.9354E-02 & 6.6667E-01 & $2.1750 E-02$ \\
\hline \multirow[t]{3}{*}{0} & 15.999400 & & & 1.9677E-02 & 3.3333E-01 & 1.0875E-02 \\
\hline & & & & 5.9031E.02 & 1.00000000 & 3.2625E-02 \\
\hline & & & & & & 3.2625E-02 \\
\hline $\mathrm{H}$ & 1.007900 & 30 & 0.5151 & $3.4435 \mathrm{E}-02$ & 6.6667E-01 & 1.9031E-02 \\
\hline \multirow[t]{3}{*}{0} & 15.999400 & & & $1.7217 \mathrm{E}-02$ & 3.3333E-01 & $9.5156 \mathrm{E}-03$ \\
\hline & & & & 5.1652E-02 & 1.00000000 & 2.8547E-02 \\
\hline & & & & & & 2.8547E-02 \\
\hline $\mathrm{H}$ & 1.007900 & 40 & 0.4415 & $2.9516 E-02$ & 6.6667E-01 & $1.6313 \mathrm{E}-02$ \\
\hline \multirow[t]{3}{*}{0} & 15.999400 & & & 1.4758E-02 & 3.3333E-01 & 8.1563E-03 \\
\hline & & & & 4.4274E-02 & 1.00000000 & 2.4469E.02 \\
\hline & & & & & & $2.4469 \mathrm{E}-02$ \\
\hline $\mathrm{H}$ & 1.007900 & 50 & 0.3679 & 2.4596E-02 & 6.6667E-01 & 1.3594E-02 \\
\hline \multirow[t]{3}{*}{0} & 15.999400 & & & 1.2298E-02 & 3.3333E-01 & 6.7969E-03 \\
\hline & & & & 3.6895E-02 & 1.00000000 & 2.0391E-02 \\
\hline & & & & & & 2.0391 E-02 \\
\hline$H$ & 1.007900 & 60 & 0.2943 & 1.9677E-02 & 6.6667E-01 & $1.0875 \mathrm{E}-02$ \\
\hline \multirow[t]{3}{*}{ 으 } & 15.999400 & & & $9.8386 \mathrm{E}-03$ & 3.3333E-01 & $5.4375 E-03$ \\
\hline & & & & 2.9516E-02 & 1.00000000 & 1.6313E-02 \\
\hline & & & & & & $1.6313 E-02$ \\
\hline $\mathrm{H}$ & 1.007900 & 70 & 0.2207 & 1.4758E-02 & $6.6667 E-01$ & $8.1563 E-03$ \\
\hline \multirow[t]{3}{*}{0} & 15.999400 & & & 7.3789E-03 & 3.3333E-01 & $4.0781 E-03$ \\
\hline & & & & 2.2137E-02 & 1.00000000 & 1.2234E-02 \\
\hline & & & & & & 1.2234 E-02 \\
\hline $\mathrm{H}$ & 1.007900 & 80 & 0.1472 & $9.8386 \mathrm{E}-03$ & 6.6667E-01 & $5.4375 E-03$ \\
\hline 0 & 15.999400 & & & 4.9193E-03 & 3.3333E-01 & $2.7188 \mathrm{E}-03$ \\
\hline & & & & 1.4758E-02 & 1.00000000 & 8.1563E-03 \\
\hline & & & & & & $8.1563 E-03$ \\
\hline $\mathrm{H}$ & 1.007900 & 90 & 0.0736 & 4.9193E-03 & $6.6667 E-01$ & $2.7188 \mathrm{E}-03$ \\
\hline 0 & 15.999400 & & & $2.4596 \mathrm{E}-03$ & 3.3333E-01 & 1.3594E-03 \\
\hline & & & & 7.3789E-03 & 1.00000000 & $4.0781 E-03$ \\
\hline & & & & & & $4.0781 \mathrm{E}-03$ \\
\hline $\mathrm{H}$ & 1.007900 & 100 & 0.0000 & $0.0000 E+00$ & \#NUM! & $0.0000 \mathrm{E}+00$ \\
\hline 0 & 15.999400 & & & $0.0000 E+00$ & \#NUM! & $0.0000 E+00$ \\
\hline & & & & $0.0000 E+00$ & \#NUMI & $0.0000 E_{4} 00$ \\
\hline & & & & & & $0.0000 E+00$ \\
\hline & & & & & & \\
\hline & & & & & & \\
\hline & & & & Area & $\mathrm{CeI}$ & \\
\hline Lattice Param & & & COMBINE-6 & (cm2) & VF & \\
\hline Pellet Radius $=$ & 0.52197 & $\mathrm{~cm}$ & Fuel & 0.8559 & 0.3239 & \\
\hline Gap Radius= & 0.53213 & $\mathrm{~cm}$ & Gap & 0.0336 & 0.0127 & \\
\hline Clad Radius $=$ & 0.61341 & $\mathrm{~cm}$ & Clad & 0.2925 & 0.1107 & \\
\hline Gap Thickness= & 0.01016 & $\mathrm{~cm}$ & $\mathrm{H} 2 \mathrm{O}$ & 1.4605 & 0.5527 & \\
\hline Clad Thickness= & 0.08128 & $\mathrm{~cm}$ & Sum= & 2.6426 & 1.0000 & \\
\hline Pitch $=$ & 1.6256 & $\mathrm{~cm}$ & & & & \\
\hline
\end{tabular}


APPENDIX D

CLAD ATOMIC NUMBER DENSITIES

D-1 


\begin{tabular}{|c|c|c|c|c|c|c|}
\hline Zircaloy-2 & & & & & & \\
\hline Density $=$ & 6.44 & $g / c c$ & & & & COMBINE-6 \\
\hline & & & & CLAD LUMP & & CELL-AVE \\
\hline Zircaloy-2 & $\bar{M}$ & $f$ & Partial Density & Aumbor Don & MCAPP & Number Den \\
\hline Isotope & Molecular Wt. & Weight Frac ${ }^{\star \star}$ & $(g / c c)$ & $(a / b / c m)$ & Fraction & $(a / b / c m)$ \\
\hline $\mathrm{Zr}$ & 91.224000 & 0.9815 & 6.3209 & $4.1726 \mathrm{E}-02$ & $9.8347 \mathrm{E}-01$ & $4.6187 \mathrm{E}-03$ \\
\hline Sn & 118.710000 & 0.0160 & 0.1030 & $5.2271 \mathrm{E}-04$ & $1.2320 \mathrm{E}-02$ & $5.7860 \mathrm{E}-05$ \\
\hline $\mathrm{Fe}$ & 55.847000 & 0.0015 & 0.0097 & $1.0416 E-04$ & $2.4551 \mathrm{E}-03$ & $1.1530 \mathrm{E}-05$ \\
\hline $\mathrm{Cr}$ & 51.996000 & 0.0010 & 0.0064 & $7.4586 \mathrm{E}-05$ & $1.7580 \mathrm{E}-03$ & $8.2561 \mathrm{E}-06$ \\
\hline & & 1.00000 & 6.44000 & 4.2428E-02 & 1.00000000 & 4.6964E-03 \\
\hline & & & & & & 4.6964E-03 \\
\hline & & & & & & \\
\hline & & & & Area & Cell & \\
\hline Lattice Param & & & COMBINE-6 & (cm2) & VF & \\
\hline Pellet Radius $=$ & 0.52197 & $\mathrm{~cm}$ & Fuel & 0.8559 & 0.3239 & \\
\hline Gap Radius $=$ & 0.53213 & $\mathrm{~cm}$ & Gæp & 0.0336 & 0.0127 & \\
\hline Clad Radius $=$ & 0.61341 & $\mathrm{~cm}$ & Clad & 0.2925 & 0.1107 & \\
\hline Gap Thickness $=$ & 0.01016 & $\mathrm{~cm}$ & $\mathrm{H} 2 \mathrm{O}$ & 1.4605 & 0.5527 & \\
\hline Clad Thickness $=$ & 0.08128 & $\mathrm{~cm}$ & Sum $=$ & 2.6426 & 1.0000 & \\
\hline Pitch $=$ & 1.6256 & $\mathrm{~cm}$ & & & & \\
\hline
\end{tabular}

